Bolm Inst. oceanogr., S Paulo, 28(1):1-52, 1979

\title{
ECOLOGIA E CONTRIBUIÇÃO DOS ANELİDEOS POLIQUETOS PARA A BIOMASSA BẼNTICA DA ZONA DAS MARÉS, NO LITORAL NORTE DO ESTADO DE SÃO PAULO*
}

\author{
A. CECILIA Z. AMARAL
}

Instituto Oceanogräfico da Universidade de São Paulo

\section{SYNOPS IS}

Polychaeta were used as indicator organisms for the study of some physical and biological conditions of the beaches of the northern coast of São Paulo. Samples were taken in 191 stations at different levels of the tidal zone, on 11 sandy beaches situated along Flamengo Bay (continent) and Palmas Bay (Anchieta Island). Sediment was analyzed for grain size distribution, porosity, organic matter and calcareous content. Qualitative and quantitative analysis of the Polychaeta fauna and measurements of temperature, dissolved oxygen and salinity of the interstitial water were made. Macrofauna was found to be completely absent from the beaches of clean coarse sand which may be due to the quite unstable condition of the sand, intensively revolved by waves action. The fine sand of many beaches offers more consistent protection for a number of burrowing animals. The Enseada and Grande beaches (respectively on the continent and on Anchieta Island) show the same very fine and homogeneous sand, and as we could expect are inhabited by the same species of Polychaeta. Nemine agilis, Arenicola brasiliensis and also Diopatra ef. cuprea are frequently found on those finesand beaches. The most selective factors were salinity and organic matter content. The euryhaline species Laeonereis culver ind Nerine agilis, have a wide distribution along the intertidal belt. Their highest density was recorded in areas of salinity below $10 \%$. The muddy sand of Saco da Ribeira beach showed the highest number of Polychaeta species, the abundance of Laeonereis culveri and Diopatra cf. cuprea contributing significantly to the biomass of this area. The occurrence of high levels of hydrogen sulphide is a characteristic on the Saco da Ribeira beach, where the sand a few centimeters below the surface is almost quite black. The corresponding very low concentrations of dissolved oxygen seems to be insufficient for many species living inside the sediment. We assume that the Polychaeta

* - Dissertação de mestrado apresentada ao Instituto Oceanogräfico da Universidade de São Paulo. Trabalho realizado com apoio financeiro da Fundação de Amparo à Pesquisa do Estado de São Paulo.

PUBL. NO 426 DO INST. OCEAN. DA USP. 
species found in those spots probably migrate to surface layers where the diffusion could supply oxygen. The Saco da Ribeira and Enseada beaches showed some degree of pollution, which may have affected the selective distribution of the Polychaeta fauna.

\section{INTRODUÇÃO}

Os anelídeos poliquetos constituem um dos maiores grupos de animais bênticos, contribuindo com uma importante parcela na alimentação de organismos marinhos de interesse econômico (Perkins \& Savage, 1975).

A sua participação nos povoamentos animais da zona das marés é de grande importância, chegando algumas espécies a alcançar altas densidades. É significativa a ação desses organismos sobre a permeabilidade e a movimentação dos sedimentos marinhos, particularmente sensível na zona das marés e em profundidades moderadas. Habitam, em sua maioria, as camadas superficiais do substrato; alguns são indicadores das condições biológicas desse ambiente e revelam com eficiência as alterações que nelas venham a ocorrer. Em determinados casos, a composição das populações de poliquetos pode constituir um índice do grau de poluição na área considerada (Reish 1955; 1973a).

Entre os trabalhos sobre ecologia de poliquetos da região entre-marés, podemos citar Amoureux (1966) e Retière (1968). No Brasil, os estudos sobre ecologia de poliquetos são escassos. Apenas Nonato (1958) abordou diversos aspectos sobre o habitat de duas espécies do gênero Arenicola da costa sul.

0 objetivo deste trabalho foi o conhecimento das condições biológicas de algumas praias do litoral norte do Estado de São Paulo, utilizando os poliquetos como organismos indicadores.

Procurou-se, atravēs da mensuração de diversos parâmetros, caracterizar o ambiente intersticial e estabelecer uma correlação com a amplitude e diversidade das populações desses anelídeos na zona das marés.

\section{ÁREA ESTUDADA}

CARACTERISTICAS DA ĀREA - A ārea estudada está próxima a um dos laboratōrios costeiros do Instituto Oceanogräfico da Universidade de São Paulo (Base Norte), no município de Ubatuba, Estado de São Paulo. Essa região do 
litoral norte tem uma costa bastante recortada, com grande número de ilhas e enseadas. As praias estudadas localizam-se na Enseada do Flamengo e face norte da Ilha Anchieta, na Enseada das Palmas (Figs 1 e 2).

A Enseada do Flamengo é profunda, aberta diretamente para o mar; com largura média de $2,5 \mathrm{~km}$, orientada aproximadamente na direção norte-sul, tendo ao fundo, em direção oeste, uma pequena baía, o Saco da Ribeira.

A linha de costa é constituída predominantemente por costões rochosos, exceto ao fundo onde se abrem amplas praias, Praia da Enseada e Praia do Saco da Ribeira. Em sua parte mais recortada, tem värias praias pequenas, relativamente expostas. 0 lado leste é formado por um costão rochoso contínuo.

Em conseqüência de sua orientação e profundidade, constitui um ambiente em que se associam ativa circulação de água e proteção contra as vagas do altomar. A presença conspícua de muitos equinodermos, gorgônias e madreporas sugere águas bem oxigenadas e de salinidade relativamente alta.

A profundidade, medida numa normal à Praia da Enseada, revela um declive suave, alcançando cerca de $20 \mathrm{~m}$, à altura da Ilha Anchieta.

Os fundos predominantes são de lodo arenoso, estando os fundos de cascalho e areia limitados a poucas regiões.

A maré média atinge o nível de $1,20 \mathrm{me}$ as grandes marés, o nível de $2 \mathrm{~m}$. A zona "entre-marés" tem amplitude variável, alcançando na Praia da Enseada cerca de $100 \mathrm{me}$ nas demais de 30-95 m, variando coma declividade. Um canal natural tem origem num ponto próximo à entrada para o Saco da Ribeira, acompanhando sua margem sul, permitindo o acesso dos barcos pesqueiros até quase o fundo dessa parte da enseada. Esse canal, cuja profundidade se mantém próxima dos $5 \mathrm{~m}$, tem provavelmente papel importante na circulação da āgua nessa ārea.

A Ilha Anchieta (antiga "Ilha dos Porcos"), está localizada próxima ao continente, com sua face suleste constituída por uma costa rochosa quase contínua e face norte bastante recortada formando uma ampla enseada. Esta, a Enseada das Palmas, é razoavelmente abrigada dos ventos que predominam na região, sofrendo a influência de rajadas ocasionais. Sua profundidade decresce regularmente, passando de cerca de $10 \mathrm{~m}$ na entrada, a 4-5 m na parte interna, mantendo-se constante até bem próximo da praia. 


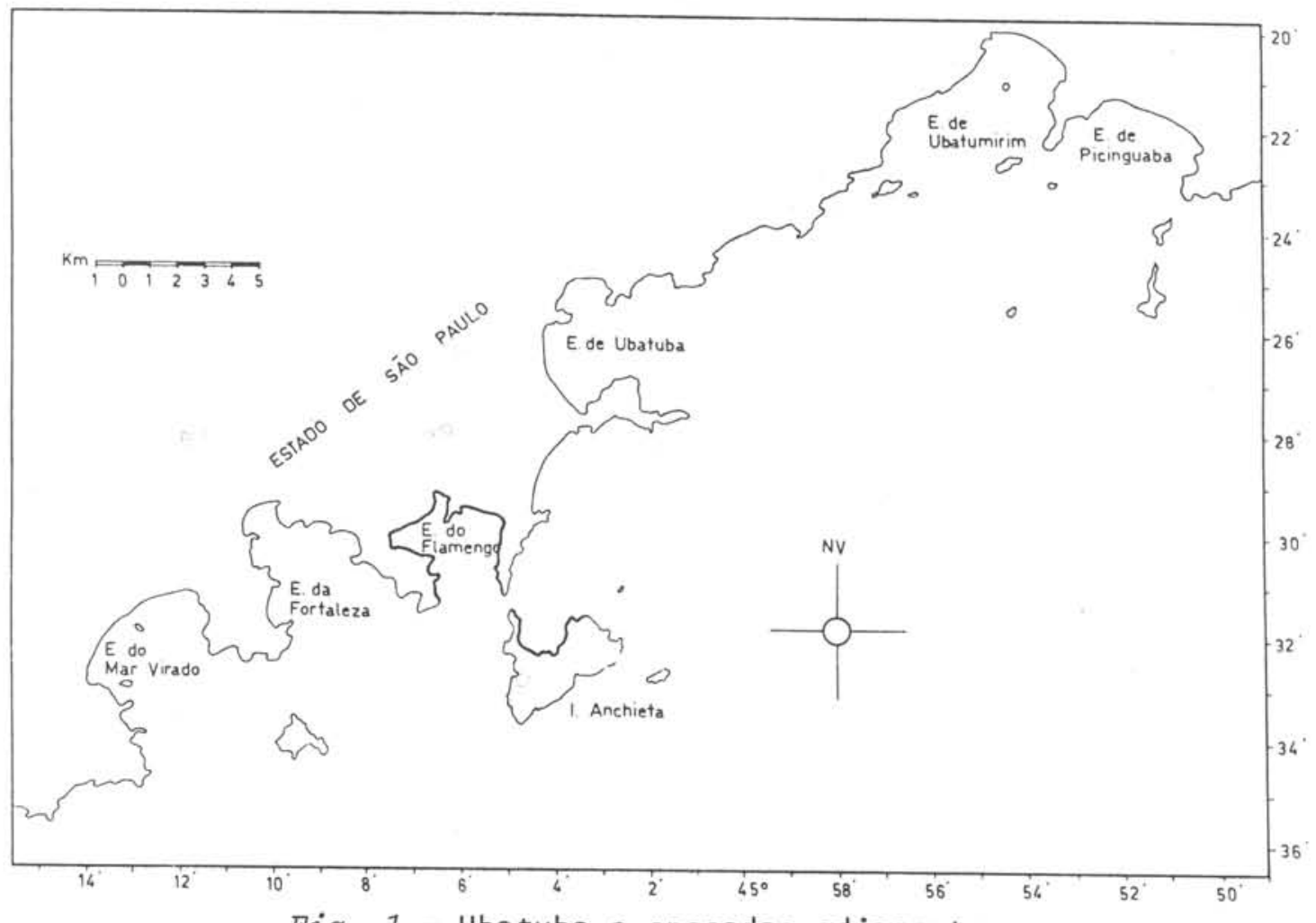

Fig. 1 - Ubatuba e enseadas adjacentes.

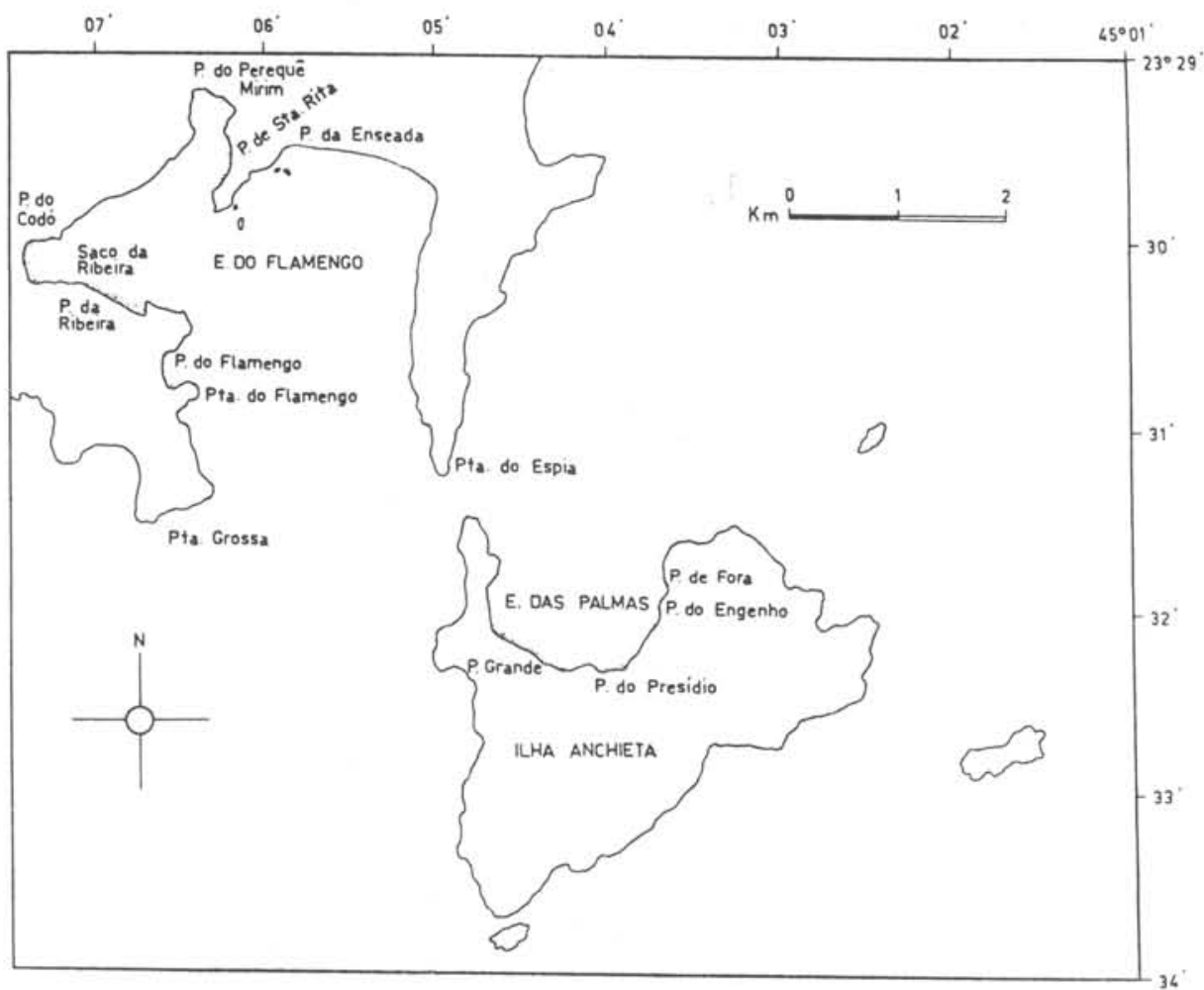

Fig. 2 - Mapa da Enseada do Flamengo e Enseada das Palmas com as praias estudadas. 
Não hã, na área abrangida pelas duas enseadas, desembocadura de curso de água doce de volume considerável e conseqüentemente, a sua influência é restrita apenas a pequenas áreas junto a riachos. Mesmona época de maior pluviosidade, a circulação da água do mar assegura a rápida mixibilidade da água doce afluente.

\section{MATERIAL E MÉTODOS}

As coletas foram efetuadas mensalmente de novembro de 1973 a janeiro de 1975, nos períodos de baixa-mar. Para escolha das épocas mais favoráveis, foi consultada a Tábua de Marés editada pela Diretoria de Hidrografia e Navegação (previsões para o porto de Angra dos Reis, RJ). A correlação entre as 1inhas de coleta e o nível real da maré foi obtida comparando as observações de campo com os registros do marégrafo na Base Norte.

Tendo em conta a diversidade de habitats originados quer pela natureza da costa, quer pela sua exposição às vagas, considerou-se necessário estudar separadamente cada uma das praias das enseadas do Flamengo (sete praias) e das Palmas (quatro praias) (Fig. 2). As onze praias estudadas foram, respectivamente: Saco da Ribeira, Codó, Enseada, Perequê-Mirim, Santa Rita, Ribeira, Flamengo, Grande, Presídio, Engenho e de Fora.

Os pontos de coleta foram escolhidos de modo a cobrir cada praia em uma densidade ideal de amostragem, o número de radiais variou em função do comprimento de cada praia. O número de estações e a distância entre elas, foram escolhidos de acordo com a largura das praias; a primeira estação sendo 1ocalizada sempre junto à linha de baixa-mar. 0 mapeamento de algumas praias e os perfís das radiais de coleta na praia do Perequê-Mirim foram obtidos por taqueometria.

0 material estudado proveio de um total de 191 estações, distribuídas nas praias acima mencionadas. Em cada uma das estações foram tomadas amostras biológicas de sedimento, e de ägua intersticial.

A) - Amostras de sedimento; para anālise do conteúdo de calcário, matéria orgânica, porosidade e granulometria.

Os teores de calcário e matéria orgânica, foram obtidos pelo método recomendado por Retière (1968). De cada amostra de sedimento foi separada uma 
parcela de cerca de $50 \mathrm{~g}$ e cuidadosamente dessalinizada por lavagens sucessivas em água doce. Após secagem em estufa aberta a cerca de $70^{\circ} \mathrm{C}$, a amostra foi homogeneizada e passada atravës de uma peneira com malha de 2,0 $\mathrm{mm}$, para eliminar partículas maiores. Subamostras de $10 \mathrm{~g}$ foram, então, retiradas para as anälises.

Calcärio: As amostras foram tratadas em Becker de $50 \mathrm{ml}$, por HC1 (ácido clorídrico) a $10 \%$, à temperatura ambiente $\left(25^{\circ} \mathrm{C}\right)$ durante $20 \mathrm{~min}$. com agitação periódica. Após cessar toda a reação visível, o líquido sobrejacente foi cuidadosamente retirado e substituído por água destilada em lavagens repetidas até remoção completa do ácido, verificada por papel tornassol, quando as amostras foram transferidas para cadinhos de porcelana previamente tarados. 0 peso do remanescente após secagem por $50 \mathrm{~min}$. em estufa a $70^{\circ} \mathrm{C}$, foi determinado em balança analítica, considerando-se a diferença como correspondente ao teor de calcário.

Matêria orgânica: A mesma amostra utilizada para a determinação do ca1cário foi submetida à temperatura de $700^{\circ} \mathrm{C}$, em mufla elétrica, por $30 \mathrm{~min}$. e após arrefecimento em ambiente seco, novamente pesada. A diferença entre o peso do material descalcificado e do calcinado, expressa, de acordo com Retière, o teor de matéria orgânica.

Porosidade: Para determinação da porosidade, foi usado o método recomendado por Amoureux (1966). Calculou-se a porosidade total a partir de amostras de $100 \mathrm{cc}$ de sedimento desidratado, como descrito a seguir.

Toma-se o peso de umbalão volumétrico de $500 \mathrm{cc}\left(\mathrm{P}_{1}\right)$ e nele introduz-se o sedimento desidratado; pesa-se o balão mais o sedimento $\left(\mathrm{P}_{2}\right)$. Uma vez completado o volume com água doce, agita-se o balão energicamente para eliminar as bolhas de ar presentes entre as partículas da amostra. Em seguida, faz-se a pesagem do balão com o sedimento e a água $\left(\mathrm{P}_{3}\right)$. A diferença de $\mathrm{P}_{3}-\mathrm{P}_{2}$ indica o peso (ou volume) da água usada para completar os $500 \mathrm{cc}$. 0 excesso de água além dos $400 \mathrm{cc}$ (volume do balão menos os $100 \mathrm{cc}$ de sedimento), é igual aos espaços vazios no sedimento, correspondendo à porosidade.

Granulometria: Para análise granulométrica as amostras foram tratadas previamente com $\mathrm{H}_{2} \mathrm{O}_{2}$ (água oxigenada) a 30 volumes, para desagregação e secagem feita em estufa a $70^{\circ} \mathrm{C}$. Em seguida, subamostras de $100 \mathrm{~g}$ foram submeti- 
das a peneiramento por 15 min., utilizando-se uma série de peneiras do "Rotap Testing Sieve Shaker and Tyler Timer L. 125", de 2,000 a 0,062 mm. 0 material retido em cada peneira foi cuidadosamente removido e pesado. Os resultados dessas pesagens foram agrupados em classes granulométricas, obedecendo a escala de Wentworth (1922): areia muito grossa $(>1,410 \mathrm{~mm})$, areia grossa $(1,000-$ $0,710 \mathrm{~mm})$, areia média $(0,500-0,360 \mathrm{~mm})$, areia fina $(0,250-0,177 \mathrm{~mm})$, areia muito fina $(0,125-0,062 \mathrm{~mm})$, lama $(<0,062 \mathrm{~mm})$.

Para os cálculos e representação dos dados foram adotados, em alguns casos, dois procedimentos para melhor demonstrar os resultados. Um deles baseouse no cálculo das porcentagens simples das diferentes classes granulométricas que compõem o sedimento, com a construção de grä́ficos de freqüência simples, como sugere Suguio (1973). Os gräficos apresentados são os da amostra mais representativa para cada praia.

0 outro procedimento baseou-se na plotagem dos dados das amostras no diagrama triangular de Shepard, modificado (Shepard \& Moore, 1954). Para a construção do diagrama as vārias classes granulométricas foram reduzidas a apenas três, agrupando-se os valores correspondentes: areia grossa $(>0,500 \mathrm{~mm})$, areia média $(0,360-0,250 \mathrm{~mm})$ e areia fina e muito fina $(0,177-0,062 \mathrm{~mm})$.

B) - Amostras biológicas: para a tomada das quais foi utilizado um delimitador, com área de $1 / 20 \mathrm{~m}^{2}$, amostrando uma coluna de $10 \mathrm{~cm}$ de profundidade. As amostras foram lavadas e triadas em peneiras com malhas de 3,0, 2,0 e $1,0 \mathrm{~mm}$. Os animais retj.dos foram transferidos para recepientes com água do mar. Levados ao laboratório para o cálculo da biomassa (peso úmido e seco) das espécies mais abundantes e posteriormente fixados em ālcool a $70 \%$.

C) - Paralelamente foram coletadas amostras de água do mar e de água intersticial em cada ponto. A salinidade foi obtida pelo método da titulação por $\mathrm{AgNO}_{3}$ (nitrato de prata), segundo Harvey (1955). O conteúdo de oxigênio dissolvido também foi determinado, empregando-se o método clássico de Winkler (Strickland \& Parsons, 1968). Foram igualmente medidas as temperaturas do ar, da água e do solo, à superfície e a $15 \mathrm{~cm}$ de profundidade, com um termômetro comum de laboratório $\left(0-40^{\circ}\right)$. As medidas de $\mathrm{pH}$ foram feitas com um pHmetro "Methrom" portātil. 


\section{CARACTERIZAÇÃO DOS AMBIENTES E CORRELAÇÃO DAS ESPÉCIES COM OS FATORES FİSICO - QUIMMICOS}

\section{PRAIA DO SACO DA RIBEIRA}

Considerações gerais - 0 Saco da Ribeira é uma baía, localizada ao fundo da Enseada do Flamengo, em direção oeste.

A maior contribuição do continente aos sedimentos da enseada, provém da área próxima ao Saco da Ribeira (Magliocca \& Kutner, 1965). Esse fato decorre de uma topografia emersa circundante favorável e de obras de terraplanagem executadas nas proximidades. De acordo com os autores citados, há um fornecimento constante de material silte-argiloso regolítico, evidenciado pelos altos valores de $\mathrm{Fe}_{2} \mathrm{O}_{3}$ (óxido ferroso) e $\mathrm{Al}_{2} \mathrm{O}_{3}$ (óxido de alumínio) e baixo teor de calcário.

A Praia do Saco da Ribeira apresenta em toda a sua extensão um suave gradiente de declividade. Sua maior largura, medida entre a linha de baixa-mar e o jundu*, ocorre na parte central com uma amplitude de aproximadamente $95 \mathrm{~m}$. Nessa ārea e no canto sul da praia (Ârea A), há desembocadura de cursos de água doce que, apesar de seu pequeno volume, tem influência na densidade populacional de algumas espécies que habitam próximo a esses riachos.

Devido aos detritos lançados por uma pequena indústria de pescado, localizada no canto Norte (Ārea B), o índice de poluição neste local é relativamente alto e parece ter influência considerāvel na distribuição das espécies que aî ocorrem.

Resultados e discussão - 0 trabalho de campo foi realizado nos meses de agosto e setembro de 1974, com seis radiais amostradas, totalizando 48 estações (Fig. 3). Os dados referentes aos fatores ambientais estão reunidos na Tabela I e Figura 4. A salinidade da água do mar variou entre $31-35 \%$. A salinidade da água intersticial è mais alta nas estações recém-expostas pela maré vazante, alcançando valores menores que $20 \%$ nas regiões mais afastadas da linha de baixa-mar. Este fato pode ser explicado pela influência dos

* - Vegetação adjacente à praia, caracterizada pela freqüência de formas xerofíticas. 


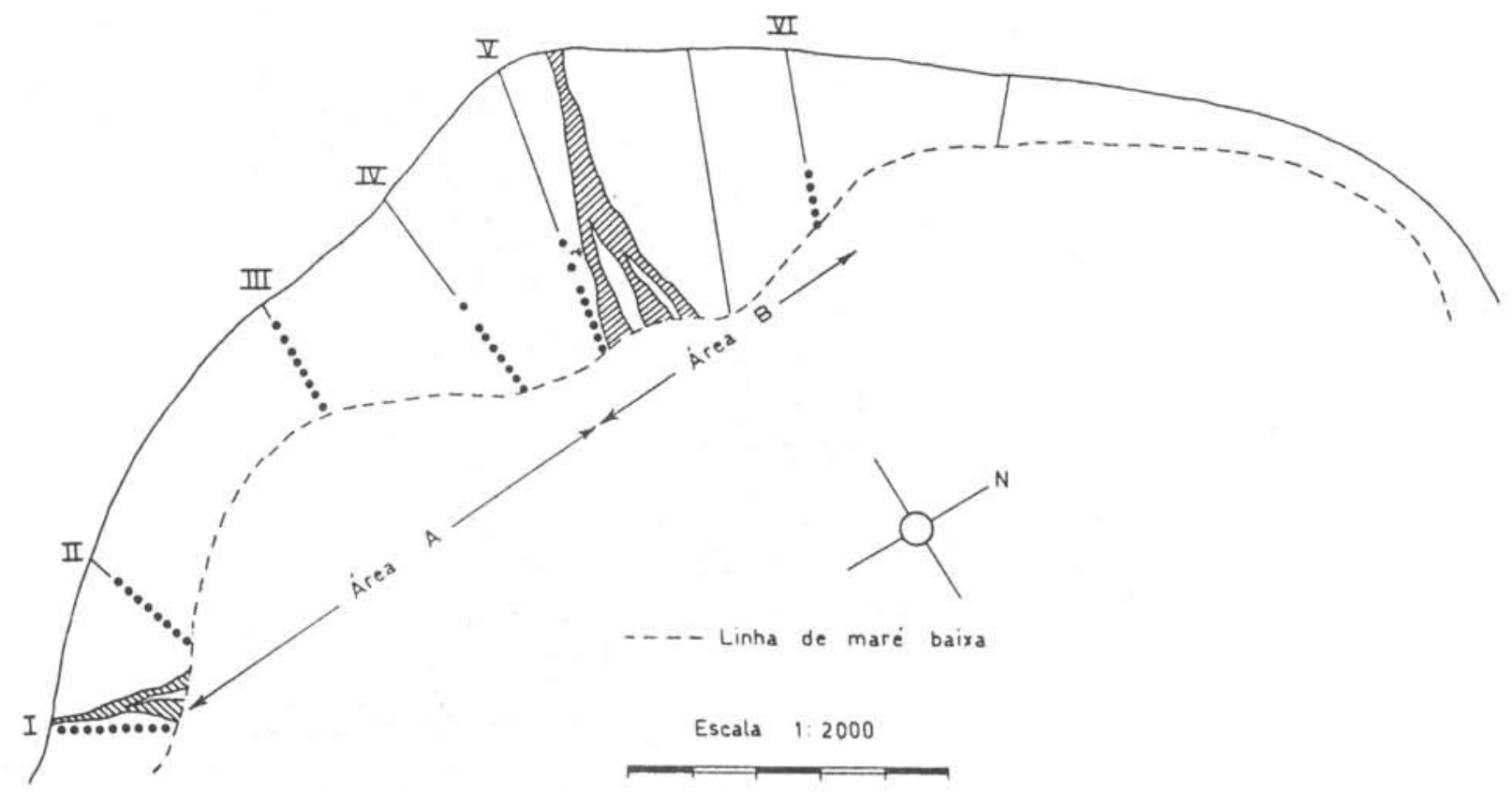

Fig. 3 - Praia do Saco da Ribeira - Radiais com respectivos pontos de amostragem. pequenos riachos da praia que acumulam água doce nestes locais. As medidas de oxigênio da água intersticial, revelaram uma quase total ausência de oxigênio dissolvido, o que pode ser atribuído à presença de $\mathrm{H}_{2} \mathrm{~S}$ (sulfeto de hidrogênio), que em meio lodoso e na presença de $\mathrm{Fe}$ (ferro) forma o FeS (sulfeto ferroso) que propicia o aparecimento da cor negra no sedimento, originando um ambiente redutor. Bruce (1928, cit.in: Newe11, 1970), também encontrou baixos valores de oxigênio dissolvido, em uma coluna de sedimento escuro a $5 \mathrm{~cm}$ abaixo da superfície, atribuindo o fato à oxidação de sulfetos de ferro formados nos depósitos sedimentares, por atividade das bactērias. Esse sedimento escuro é encontrado em quase toda a extensão da praia, em diferentes profundidades. $0 \mathrm{pH}$ da água intersticial variou entre 7,8-8,0. Em conseqüência da presença de $\mathrm{H}_{2} \mathrm{~S}$ (sulfeto de hidrogênio) seria de se esperar um ambiente mais ácido; porém, os valores observados podem ter sido alterados pelo $\mathrm{pH}$ mais alcalino da água do mar.

A granulometria do sedimento pode ser considerada homogênea em toda a praia. As amostras de sedimentos, submetidas à análise mecânica, apresentaram tama- 
TABELA I - Dados físico-químicos das estações da Praia do Saco da Ribeira

\begin{tabular}{|c|c|c|c|c|c|c|c|c|c|c|}
\hline \multirow{3}{*}{$\begin{array}{l}\text { Radial } \\
\text { (data) }\end{array}$} & \multirow{3}{*}{ Hora } & \multirow{3}{*}{$\begin{array}{c}\text { Local } \\
\text { de } \\
\text { coleta }\end{array}$} & \multirow{3}{*}{$\pi_{\text {gua }}$} & \multicolumn{3}{|c|}{ I $\left({ }^{\circ} \mathrm{C}\right)$} & \multirow{3}{*}{$\begin{array}{c}S \\
(0 / 00)\end{array}$} & \multirow{3}{*}{$\begin{array}{c}\mathrm{O}_{2} \\
(\mathrm{~m} 1 / 1)\end{array}$} & \multirow{3}{*}{$\underset{(z)}{\mathrm{CaCO}_{3}}$} & \multirow{3}{*}{$\begin{array}{l}\text { Matéria } \\
\text { orgânice } \\
\quad \text { (Z) }\end{array}$} \\
\hline & & & & & Sedi & ento & & & & \\
\hline & & & & AT & Sup. & Fund. & & & & \\
\hline \multirow{10}{*}{$28 / 09 / 74$} & $09: 00$ & 9 & - & 22,4 & 23,6 & 22,1 & 23,60 & 0,91 & 0,00 & 0,80 \\
\hline & - & 8 & - & 22,1 & 22,5 & 22,4 & 02,00 & 2,04 & 0,00 & 0,50 \\
\hline & - & 7 & - & 21,8 & 23,5 & 23,5 & 21,30 & 0,00 & 0,00 & 0,40 \\
\hline & - & 6 & - & 21,7 & 23,6 & 23,5 & 27,20 & 0,00 & 0,00 & 0,00 \\
\hline & - & 5 & - & 21,7 & 23,5 & 23,7 & 30,00 & 0,00 & 0,00 & 0,40 \\
\hline & - & 4 & - & 22,0 & 23,2 & 23,6 & 33,10 & 0.00 & 0,30 & 0,80 \\
\hline & - & 3 & - & 21,8 & 23,4 & 23,8 & 33,08 & 0,00 & 0,00 & 2,10 \\
\hline & - & 2 & - & 21,8 & 23,4 & 23,8 & 32,70 & 0,00 & 0,30 & 0,60 \\
\hline & - & 1 & - & 21,6 & 23,4 & 24,0 & 34,30 & 0,00 & 0,00 & 0,70 \\
\hline & $07: 00$ & Mar & 22,8 & 21,6 & - & - & 32,80 & 3,90 & - & - \\
\hline \multirow{10}{*}{$\begin{array}{c}\text { II } \\
14 / 08 / 74\end{array}$} & $09: 15$ & 9 & - & 19,8 & 18,1 & 19,0 & $\sigma 9,80$ & 0,60 & 0,30 & 0,70 \\
\hline & - & 8 & - & 21,1 & 19,8 & 19,1 & 22,98 & - & 0,00 & 1,00 \\
\hline & - & 7 & - & 21,1 & 19,4 & 18,8 & 30,00 & 0,00 & 0,00 & 0,50 \\
\hline & - & 6 & - & 18,2 & 18,6 & 19,3 & 32,06 & 0,00 & 0,20 & 1,10 \\
\hline & - & 5 & - & 18,5 & 18,5 & 20,2 & 33,22 & 0.00 & 0,20 & 1,20 \\
\hline & - & 4 & - & 18,5 & 18,5 & 20.3 & 33,52 & 0,00 & 0,10 & 1,10 \\
\hline & - & 3 & - & 18,5 & 18,5 & 20,3 & 33,82 & 0,00 & 1,00 & 1,00 \\
\hline & - & 2 & - & 18,2 & 18,5 & 20,5 & 34,28 & 0,00 & 0,60 & 1,20 \\
\hline & - & 1 & - & 17,5 & 18,0 & 21,2 & 34,18 & 0,00 & 0,20 & 1,00 \\
\hline & $07: 00$ & Mar & 21,0 & 17,5 & - & - & 35.48 & 4,03 & - & - \\
\hline \multirow{10}{*}{$\begin{array}{c}\text { III } \\
15 / 08 / 74\end{array}$} & $09: 00$ & 9 & - & 21,8 & 21,8 & 20,6 & 11,31 & 1,13 & 0,50 & 1,50 \\
\hline & - & 8 & - & 21,0 & 21,0 & 20,5 & 21,58 & 0,00 & 0,30 & 1,20 \\
\hline & - & 7 & - & 21,2 & 21,2 & 20,5 & 22,78 & 0,00 & 0,30 & 0,70 \\
\hline & - & 6 & - & 24,4 & 20,5 & 20,3 & 31,66 & 0,00 & 0,30 & 0,70 \\
\hline & - & 5 & - & 24,5 & 20,6 & 21,0 & 31.36 & 0,00 & 0,60 & 1,00 \\
\hline & - & 4 & - & 18,0 & 21,0 & 21,0 & 32,82 & 0,00 & 0,20 & 1,00 \\
\hline & - & 3 & - & 24,0 & 21,0 & 21,2 & 32,42 & 0,00 & 0,20 & 1,80 \\
\hline & - & 2 & - & 24,0 & 20,6 & 21,6 & 33,62 & 0,00 & 0,50 & 1,00 \\
\hline & - & 1 & - & 18,5 & 20,5 & 21,3 & 33,62 & 0,00 & 0,20 & 1,00 \\
\hline & $07: 45$ & Mar & 21,5 & 18,0 & - & - & 34,38 & 1,73 & - & - \\
\hline \multirow{9}{*}{$\begin{array}{c}\text { IV } \\
02 / 09 / 74\end{array}$} & $10: 45$ & 8 & - & 19,5 & 22,0 & 22,5 & 27,92 & 0,00 & 0,20 & 1,80 \\
\hline & - & 7 & - & 19,0 & 22,0 & 22,5 & 31,06 & 0,00 & 0,30 & 1,00 \\
\hline & - & 6 & - & 19,5 & 22,0 & 22,5 & 29,00 & 0,00 & 0,00 & 1,00 \\
\hline & - & 5 & - & 19,5 & 22,0 & 22.5 & 34,22 & 0,00 & 0,30 & 1,00 \\
\hline & - & 4 & - & 19,5 & 22,0 & 22,5 & 33,02 & 0,00 & 0,00 & 0,80 \\
\hline & - & 3 & - & 19,5 & 22,0 & 22,5 & 31,16 & 0,00 & 0,00 & 0,00 \\
\hline & - & 2 & - & 19,5 & 22,0 & 22,5 & 31,16 & 0,00 & 0,20 & 0,90 \\
\hline & - & 1 & - & 19,0 & 21,5 & 22.5 & 33,42 & 0,00 & 0,00 & 0,00 \\
\hline & $09: 00$ & Mar & 21,5 & 19,0 & - & & 33,22 & 4,31 & - & - \\
\hline \multirow{9}{*}{$\begin{array}{c}v \\
03 / 09 / 74\end{array}$} & $11: 00$ & 8 & - & 17,3 & 21,6 & 21,2 & 13,80 & 0,07 & 0,00 & 0.50 \\
\hline & - & 7 & - & 17,5 & 21,0 & 21,6 & 31,16 & 0,11 & 0,00 & 1,00 \\
\hline & - & 6 & - & 17,5 & 20,1 & 21,2 & 30,20 & 0,11 & 0,00 & 0,70 \\
\hline & - & 5 & - & 17,4 & 19,9 & 21,0 & 28,02 & 0,10 & 0,00 & 1,00 \\
\hline & - & 4 & - & 17,4 & 20.0 & 21,7 & 32,20 & 0,11 & 0,00 & 0,80 \\
\hline & - & 3 & - & 17,1 & 19,0 & 20,8 & 32,96 & 0,11 & 0,00 & 0,50 \\
\hline & - & 2 & - & 17,3 & 18,2 & 22,0 & 20,88 & 0,31 & 0,00 & 0,50 \\
\hline & - & 1 & - & 17,2 & 20,6 & 22,1 & 34,12 & 1,67 & 0,00 & 0,20 \\
\hline & $10: 00$ & Max & 20,0 & 17,2 & & & 31,26 & 4,67 & & \\
\hline \multirow{5}{*}{$\begin{array}{c}\text { VI } \\
03 / 09 / 74\end{array}$} & $12: 00$ & 5 & - & 17,0 & 22,2 & 22,3 & 29,80 & 0,00 & 0,00 & 1,50 \\
\hline & - & 4 & - & 17,5 & 22,2 & 22,3 & 30,86 & 0,00 & 0,00 & 0,80 \\
\hline & - & 3 & - & 17,5 & 23,0 & 22,3 & 28,02 & 0,00 & 0,00 & 0,80 \\
\hline & - & 2 & - & 17,5 & 21,5 & 22,0 & 34,32 & 0,00 & 0,00 & 0,80 \\
\hline & $11: 00$ & 1 & 20,0 & 17.5 & 21,6 & 21,2 & 34.88 & 0,00 & 0.00 & 0,20 \\
\hline
\end{tabular}




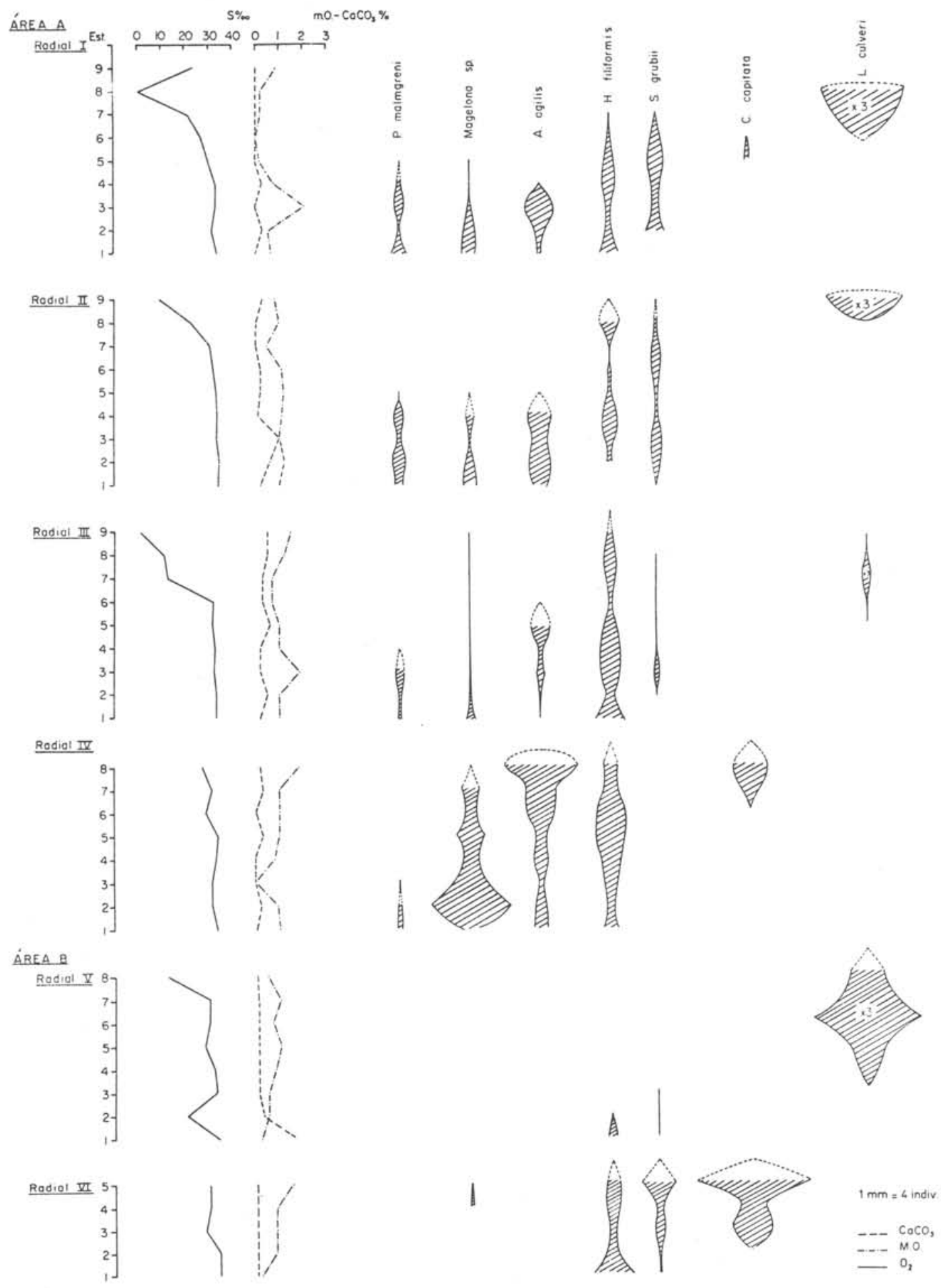

Fig. 4 - Distribuição horizontal de alguns parâmetros ambientais e das espēcies de poliquetos mais importantes, em relação a $1 / 120 \mathrm{~m}^{2}$, nas 6 radiais amostradas para a Praia do Saco da Ribeira. As estações de n? l estão localizadas junto à linha d'ägua. 
nho médio dos grãos entre 1,000-0,500 mm, caracterizando-se como areia média (Fig. 5). A porosidade da areia, determinada para os pontos de ocorrência

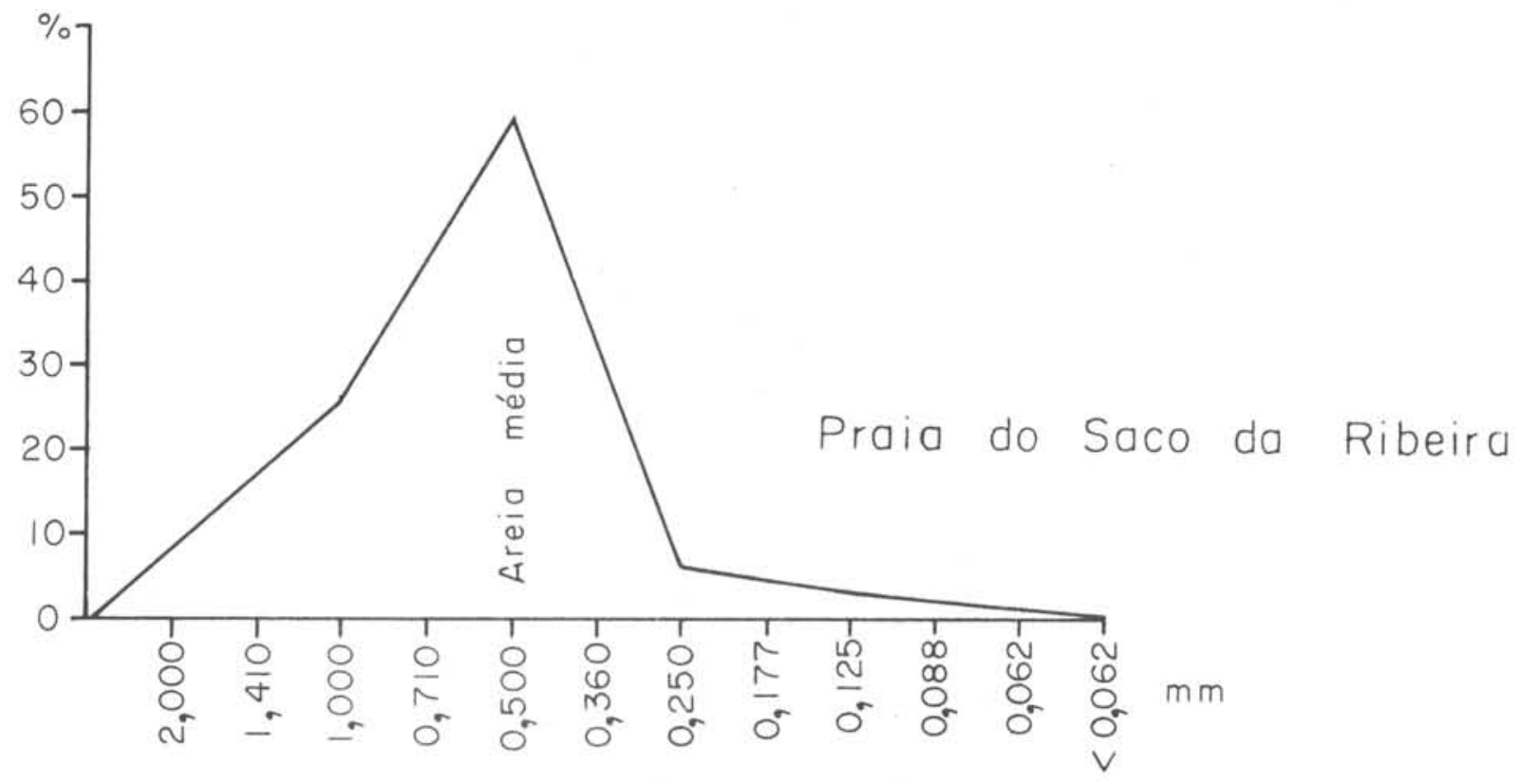

Fig. 5 - Gräfico da frequência simples da distribuição granulomëtrica. da espécie dominante nesta praia, Laeonereis culveri, alcançou cerca de $43 \%$. 0 teor em calcärio foi baixo, podendo ser comparado com os valores obtidos por Magliocca \& Kutner (1965), que os justificam como resultado da grande influência dos sedimentos de origem continental. 0 conteúdo em matéria orgânica variou entre 0,5 - 2\%; os detritos lançados à praia pela indústria de. pescado, certamente constituem o fator responsävel pela flutuação desses valores.

As medidas de temperatura do ar, da superfície do sedimento e a $15 \mathrm{~cm}$ de profundidade, sofreram pequenas flutuações durante o período de coleta.

As espécies de poliquetos, sua ocorrência e densidade na praia, estão apresentadas na Tabela II e as formas mais comuns constam da Figura 4. A espécie numericamente mais importante é Laeonereis culveri, cuja densidade nos pontos altos da praia e próximos aos riachos, alcançou cerca de 5.600 indivíduos $/ \mathrm{m}^{2}$. Para esta espécie de tão alta densidade, foi avaliado o peso, que contribui ponderavelmente para a biomassa total da região estudada. 0 peso úmido de 50 indivíduos alcançou $1,410 \mathrm{~g}$ e o peso seco, 0,446 g, o que permite calcular um peso úmido de cerca de $157,92 \mathrm{~g} / \mathrm{m}^{2}$, para as regiões de maior densidade. 
TABELA II - Ocorrência das espécies de poliquetos na Praia do Saco da Ribeira. Nümero de exemplares em amostras de $1 / 20 \mathrm{~m}^{2}$

\begin{tabular}{|c|c|c|c|c|c|c|c|c|c|c|c|c|c|}
\hline 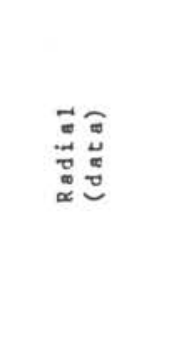 & 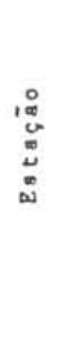 & 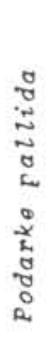 & 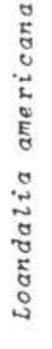 & 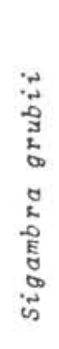 & 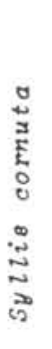 & 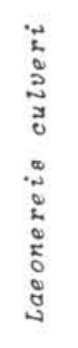 & 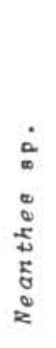 & 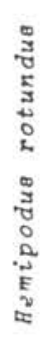 & 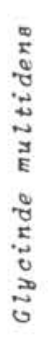 & 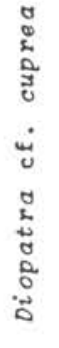 & 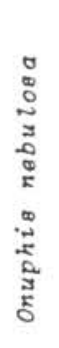 & 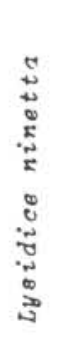 & 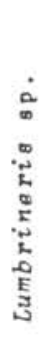 \\
\hline$\frac{1}{28 / 09 / 74}$ & $\begin{array}{l}9 \\
8 \\
7 \\
6 \\
5 \\
4 \\
3 \\
2 \\
1\end{array}$ & $\begin{array}{l}\bar{z} \\
\bar{z} \\
\overline{-} \\
\overline{-} \\
\overline{-}\end{array}$ & $\begin{array}{l}\bar{z} \\
\bar{z} \\
\bar{z} \\
\bar{z} \\
\overline{-}\end{array}$ & $\begin{array}{r}- \\
1 \\
8 \\
14 \\
5 \\
6 \\
14 \\
-\end{array}$ & $\begin{array}{l}\bar{z} \\
\overline{-} \\
\overline{-} \\
1\end{array}$ & $\begin{array}{c}213 \\
170 \\
45 \\
= \\
= \\
= \\
= \\
-\end{array}$ & $\begin{array}{l}= \\
= \\
= \\
\overline{2} \\
-\end{array}$ & $\begin{array}{l}\bar{y} \\
1 \\
4 \\
1 \\
5 \\
z \\
\overline{-}\end{array}$ & $\begin{array}{l}\bar{z} \\
\bar{z} \\
\overline{-} \\
\overline{-}\end{array}$ & $\begin{array}{l}- \\
\overline{-} \\
\overline{-} \\
\overline{1} \\
1 \\
-\end{array}$ & $\begin{array}{l}\bar{z} \\
\bar{z} \\
\bar{z} \\
\bar{z}\end{array}$ & $\begin{array}{l}\bar{z} \\
z \\
z \\
z \\
z\end{array}$ & $\begin{array}{l}\bar{z} \\
\bar{z} \\
\bar{z} \\
\overline{1}\end{array}$ \\
\hline $\begin{array}{c}11 \\
14 / 08 / 74\end{array}$ & $\begin{array}{l}9 \\
8 \\
7 \\
6 \\
5 \\
4 \\
3 \\
2 \\
1\end{array}$ & $\begin{array}{l}\bar{z} \\
\bar{z} \\
\bar{z} \\
\overline{-} \\
\overline{-}\end{array}$ & $\begin{array}{l}\bar{z} \\
\bar{z} \\
\bar{z} \\
\bar{y} \\
\overline{-}\end{array}$ & $\begin{array}{r}- \\
3 \\
5 \\
5 \\
3 \\
3 \\
3 \\
10 \\
6 \\
1\end{array}$ & $\begin{array}{l}= \\
\bar{z} \\
\bar{z} \\
\bar{z}\end{array}$ & $\begin{array}{l}99 \\
12 \\
= \\
= \\
= \\
= \\
-\end{array}$ & $\begin{array}{l}\bar{y} \\
\overline{-} \\
\overline{5} \\
1 \\
\overline{-}\end{array}$ & $\begin{array}{l}- \\
2 \\
4 \\
2 \\
1 \\
- \\
5 \\
- \\
-\end{array}$ & $\begin{array}{l}\bar{z} \\
\bar{z} \\
\bar{z} \\
\bar{z} \\
\overline{-}\end{array}$ & $\begin{array}{l}- \\
- \\
1 \\
-2 \\
3 \\
4 \\
4 \\
2\end{array}$ & $\begin{array}{l}\bar{z} \\
\bar{z} \\
\bar{z} \\
\bar{z} \\
\overline{-}\end{array}$ & $\begin{array}{l}\overline{ } \\
\bar{z} \\
\bar{z} \\
\bar{z}\end{array}$ & $\begin{array}{l}\bar{z} \\
\bar{z} \\
\bar{y} \\
\bar{z} \\
\overline{-}\end{array}$ \\
\hline $\begin{array}{c}\mathrm{III} \\
15 / 08 / 74\end{array}$ & $\begin{array}{l}9 \\
8 \\
7 \\
6 \\
5 \\
4 \\
3 \\
2 \\
1\end{array}$ & $\begin{array}{l}\bar{z} \\
\bar{z} \\
\bar{z} \\
\bar{z}\end{array}$ & $\begin{array}{l}\overline{-} \\
\overline{-} \\
\overline{-} \\
\overline{2} \\
1 \\
2\end{array}$ & $\begin{array}{l}\overline{1} \\
\bar{z} \\
\bar{z} \\
\overline{4} \\
1 \\
-\end{array}$ & $\begin{array}{l}\bar{z} \\
\bar{z} \\
\bar{z} \\
\bar{z} \\
\overline{-}\end{array}$ & $\begin{array}{r}1 \\
5 \\
21 \\
3 \\
2 \\
-2 \\
= \\
= \\
-\end{array}$ & $\begin{array}{l}\bar{z} \\
\bar{z} \\
\bar{z} \\
\bar{z} \\
\overline{-}\end{array}$ & $\begin{array}{l}\overline{ } \\
\bar{z} \\
\bar{z} \\
\bar{z}\end{array}$ & $\begin{array}{l}\bar{z} \\
\bar{z} \\
\bar{z} \\
\bar{z}\end{array}$ & $\begin{array}{l}- \\
\bar{z} \\
\overline{2} \\
1 \\
1 \\
1 \\
2 \\
2\end{array}$ & $\begin{array}{l}\overline{ } \\
\bar{z} \\
\bar{y} \\
\bar{y} \\
1\end{array}$ & $\begin{array}{l}= \\
= \\
= \\
z \\
z\end{array}$ & $\begin{array}{l}\bar{z} \\
\bar{z} \\
\bar{z} \\
\bar{z}\end{array}$ \\
\hline $\begin{array}{c}\text { IV } \\
02 / 09 / 74\end{array}$ & $\begin{array}{l}8 \\
7 \\
6 \\
5 \\
4 \\
3 \\
2 \\
1\end{array}$ & $\begin{array}{l}- \\
\overline{-} \\
\overline{-} \\
1 \\
1 \\
-\end{array}$ & $\begin{array}{l}1 \\
3 \\
1 \\
- \\
- \\
2 \\
2 \\
1\end{array}$ & $\begin{array}{l}- \\
6 \\
8 \\
4 \\
3 \\
2 \\
1 \\
1\end{array}$ & $\begin{array}{l}\overline{-} \\
\overline{-} \\
\overline{-} \\
\overline{1} \\
\overline{-}\end{array}$ & $\begin{array}{l}z \\
z \\
z \\
z \\
z\end{array}$ & $\begin{array}{l}- \\
1 \\
5 \\
4 \\
3 \\
7 \\
-\end{array}$ & $\begin{array}{l}\bar{z} \\
\bar{z} \\
\bar{z} \\
\bar{z}\end{array}$ & $\begin{array}{l}- \\
- \\
1 \\
2 \\
1 \\
- \\
-\end{array}$ & $\begin{array}{l}1 \\
1 \\
3 \\
3 \\
8 \\
9 \\
4\end{array}$ & $\begin{array}{l}\bar{z} \\
\bar{z} \\
\bar{z} \\
\overline{-}\end{array}$ & $\begin{array}{l}\bar{z} \\
\bar{z} \\
\bar{z} \\
\overline{1}\end{array}$ & $\begin{array}{l}z \\
z \\
z \\
z\end{array}$ \\
\hline $\begin{array}{c}\nabla \\
03 / 09 / 74\end{array}$ & $\begin{array}{l}8 \\
7 \\
6 \\
5 \\
4 \\
3 \\
2 \\
1 \\
\end{array}$ & 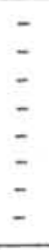 & $\begin{array}{l}\overline{ } \\
\bar{z} \\
\overline{1}\end{array}$ & $\begin{array}{l}\bar{z} \\
\overline{1} \\
\overline{1} \\
\overline{1}\end{array}$ & $\begin{array}{l}\bar{z} \\
\bar{z} \\
\bar{z} \\
\bar{z}\end{array}$ & $\begin{array}{r}86 \\
135 \\
280 \\
115 \\
32 \\
1 \\
- \\
-\end{array}$ & $\begin{array}{l}\bar{z} \\
\bar{z} \\
- \\
\vdots \\
-\end{array}$ & $\begin{array}{l}- \\
- \\
- \\
- \\
3 \\
1 \\
-\end{array}$ & $\begin{array}{l}- \\
z \\
\overline{1} \\
z \\
z\end{array}$ & $\begin{array}{l}\bar{z} \\
z \\
z \\
z \\
z\end{array}$ & $\begin{array}{l}\bar{z} \\
\bar{z} \\
\bar{z} \\
\bar{z}\end{array}$ & $\begin{array}{l}- \\
= \\
= \\
z \\
=\end{array}$ & $\begin{array}{l}z \\
z \\
z \\
z \\
z\end{array}$ \\
\hline $\begin{array}{c}\mathrm{VI} \\
03 / 09 / 74\end{array}$ & $\begin{array}{l}5 \\
4 \\
3 \\
2 \\
1\end{array}$ & 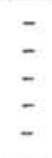 & $\begin{array}{l}z \\
z\end{array}$ & $\begin{array}{r}31 \\
5 \\
9 \\
2 \\
2\end{array}$ & $\begin{array}{l}\bar{z} \\
\bar{z}\end{array}$ & $-^{1}$ & $\begin{array}{l}\overline{1} \\
\overline{-} \\
-\end{array}$ & $\begin{array}{l}- \\
6 \\
\overline{1} \\
\overline{1}\end{array}$ & $\begin{array}{l}z \\
z\end{array}$ & $\begin{array}{l}\bar{z} \\
\bar{z}\end{array}$ & $\begin{array}{l}\bar{z} \\
\bar{z}\end{array}$ & $\begin{array}{l}- \\
\bar{z} \\
\overline{-}\end{array}$ & $\begin{array}{l}\bar{z} \\
\bar{z}\end{array}$ \\
\hline
\end{tabular}


TABELA II - Ocorrência das espécies de poliquetos na Praia do Saco da Ribeira. Nümero de exemplares em amostras de $1 / 20 \mathrm{~m}^{2}$

\begin{tabular}{|c|c|c|c|c|c|c|c|c|c|c|c|c|c|}
\hline 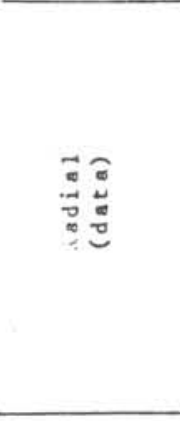 & 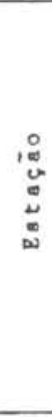 & 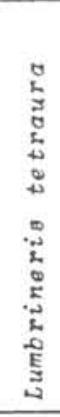 & 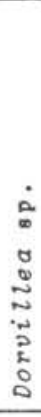 & 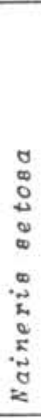 & 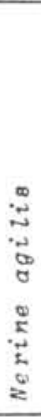 & 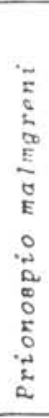 & $\begin{array}{l}\dot{a} \\
\alpha \\
0 \\
\tilde{\Sigma} \\
0 \\
\tilde{N} \\
\dot{0} \\
0 \\
\Sigma\end{array}$ & 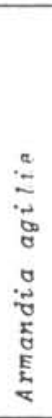 & 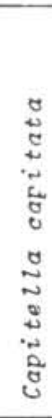 & 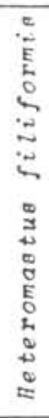 & 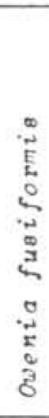 & 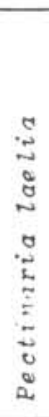 & 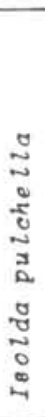 \\
\hline $\begin{array}{c}I \\
28 / 09 / 74\end{array}$ & $\begin{array}{l}9 \\
8 \\
7 \\
6 \\
5 \\
4 \\
3 \\
2 \\
1 \\
\end{array}$ & $\begin{array}{r} \\
- \\
- \\
1 \\
10 \\
6 \\
- \\
2\end{array}$ & $\begin{array}{l}\bar{y} \\
\bar{z} \\
\bar{z} \\
\bar{y}\end{array}$ & $\begin{array}{l}\bar{z} \\
\bar{z} \\
\bar{z}\end{array}$ & $\begin{array}{l}\bar{y} \\
\bar{z} \\
\bar{z}\end{array}$ & $\begin{array}{r}= \\
\\
\overline{4} \\
4 \\
7 \\
10 \\
10\end{array}$ & $\begin{array}{l}5 \\
\bar{y} \\
\overline{-} \\
\overline{2} \\
10 \\
11\end{array}$ & $\begin{array}{r}- \\
\\
- \\
1 \\
24 \\
10 \\
3\end{array}$ & $\begin{array}{l}- \\
\overline{1} \\
2 \\
- \\
- \\
-\end{array}$ & $\begin{array}{r}- \\
1 \\
1 \\
2 \\
5 \\
10 \\
4 \\
5 \\
14\end{array}$ & $\begin{array}{l}\overline{ } \\
\overline{ } \\
\bar{z} \\
\overline{-} \\
\overline{-}\end{array}$ & $\begin{array}{l}\bar{z} \\
\bar{z} \\
\bar{z}\end{array}$ & $\begin{array}{l}\bar{y} \\
\bar{z} \\
\bar{y}\end{array}$ \\
\hline $\begin{array}{c}\text { II } \\
14 / 08 / 74\end{array}$ & $\begin{array}{l}9 \\
8 \\
7 \\
6 \\
5 \\
4 \\
3 \\
2 \\
1 \\
\end{array}$ & $\begin{array}{l}- \\
1 \\
3 \\
\overline{-} \\
\bar{z} \\
\overline{-}\end{array}$ & $\begin{array}{l}\bar{z} \\
\bar{z} \\
\bar{z}\end{array}$ & $\begin{array}{l}\bar{z} \\
\bar{z} \\
\bar{z} \\
\bar{z}\end{array}$ & $\begin{array}{l}\overline{-} \\
\overline{-}\end{array}$ & $\begin{array}{r}- \\
\\
- \\
1 \\
8 \\
4 \\
11 \\
7\end{array}$ & $\begin{array}{r}- \\
\\
\\
\\
5 \\
5 \\
1 \\
5 \\
15\end{array}$ & $\begin{array}{r}5 \\
\\
\\
\\
2 \\
13 \\
19 \\
12 \\
12\end{array}$ & $\begin{array}{l}\overline{ } \\
\overline{-} \\
\overline{ } \\
\overline{ } \\
\overline{-}\end{array}$ & $\begin{array}{r}- \\
15 \\
1 \\
2 \\
3 \\
13 \\
8 \\
4 \\
-\end{array}$ & 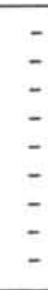 & $\begin{array}{l}\bar{z} \\
\bar{z} \\
\bar{z} \\
\bar{z}\end{array}$ & 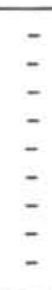 \\
\hline $\begin{array}{c}\text { III } \\
15 / 08 / 74\end{array}$ & $\begin{array}{l}9 \\
8 \\
7 \\
6 \\
5 \\
4 \\
3 \\
2 \\
1\end{array}$ & $\begin{array}{l}1 \\
- \\
1 \\
- \\
- \\
-\end{array}$ & $\begin{array}{l}\bar{z} \\
\bar{z} \\
\overline{-}\end{array}$ & $\begin{array}{l}\overline{-} \\
\bar{z} \\
\bar{y}\end{array}$ & $\begin{array}{l}\bar{z} \\
\bar{z}\end{array}$ & $\begin{array}{l}\overline{-} \\
\bar{z} \\
\bar{z}\end{array}$ & $\begin{array}{l}1 \\
\overline{-} \\
\overline{1} \\
\overline{2} \\
6\end{array}$ & $\begin{array}{r}- \\
- \\
- \\
- \\
15 \\
4 \\
6 \\
2 \\
1\end{array}$ & $\begin{array}{l}\overline{ } \\
\bar{y} \\
\bar{E} \\
\overline{-}\end{array}$ & $\begin{array}{r}3 \\
11 \\
8 \\
2 \\
12 \\
15 \\
15 \\
7 \\
23\end{array}$ & $\begin{array}{l}- \\
\overline{-} \\
\overline{1} \\
\overline{7} \\
4 \\
55\end{array}$ & $\begin{array}{r}- \\
\\
1 \\
1 \\
- \\
11 \\
3 \\
4\end{array}$ & $\begin{array}{r}1 \\
2 \\
- \\
-2 \\
5 \\
15 \\
5\end{array}$ \\
\hline $\begin{array}{c}\text { IV } \\
02 / 09 / 74\end{array}$ & $\begin{array}{l}7 \\
6 \\
5 \\
4 \\
3 \\
2 \\
1\end{array}$ & $\begin{array}{l}2 \\
1 \\
3 \\
- \\
- \\
= \\
=\end{array}$ & $\overline{-}$ & - & - & 4 & 12 & $\begin{array}{r}61 \\
25 \\
24 \\
8 \\
12 \\
4 \\
8 \\
13\end{array}$ & $\begin{array}{l}27 \\
\overline{1} \\
= \\
= \\
-\end{array}$ & $\begin{array}{r}15 \\
12 \\
23 \\
18 \\
11 \\
8 \\
5 \\
13\end{array}$ & $\begin{array}{l}\bar{z} \\
\bar{z} \\
\overline{-}\end{array}$ & $\begin{array}{l}5 \\
\overline{5} \\
\overline{-} \\
\overline{-}\end{array}$ & $\begin{array}{l}\overline{1} \\
4 \\
2 \\
5 \\
- \\
\overline{1} \\
1\end{array}$ \\
\hline $\begin{array}{c}v \\
03 / 09 / 74\end{array}$ & $\begin{array}{l}8 \\
7 \\
6 \\
5 \\
4 \\
3 \\
2 \\
1\end{array}$ & $\begin{array}{l}\bar{z} \\
\bar{z} \\
\overline{2} \\
\overline{-}\end{array}$ & - & - & $\overline{-}$ & $\begin{array}{l}\bar{z} \\
\bar{z} \\
\bar{z}\end{array}$ & $\begin{array}{l}\overline{-} \\
\bar{z} \\
\bar{z} \\
\overline{-}\end{array}$ & $\begin{array}{l}\bar{z} \\
\bar{z} \\
\bar{z} \\
\overline{-}\end{array}$ & $\begin{array}{l}\bar{y} \\
\bar{y} \\
\bar{y}\end{array}$ & $\begin{array}{l}5 \\
= \\
\overline{5} \\
1 \\
5\end{array}$ & $\begin{array}{l}I \\
\bar{z} \\
\bar{z}\end{array}$ & $\begin{array}{l}\overline{ } \\
\bar{z} \\
\overline{ } \\
\overline{ }\end{array}$ & $\begin{array}{l}\bar{z} \\
\vdots \\
\vdots \\
z\end{array}$ \\
\hline $\begin{array}{c}\mathrm{VI} \\
03 / 09 / 74\end{array}$ & $\begin{array}{l}5 \\
4 \\
3 \\
2 \\
1\end{array}$ & $\begin{array}{r}10 \\
5 \\
- \\
-\end{array}$ & $\overline{-}$ & $\begin{array}{l}\bar{z} \\
\bar{z}\end{array}$ & $\begin{array}{l}\overline{1} \\
\bar{z}\end{array}$ & $\overline{-}$ & $\begin{array}{l}1 \\
2 \\
- \\
-\end{array}$ & $\begin{array}{l}2 \\
- \\
-\end{array}$ & $\begin{array}{r}36 \\
4\end{array}$ & $\begin{array}{r}11 \\
13 \\
5 \\
7 \\
35\end{array}$ & $\overline{-}$ & $\overline{-}$ & $\begin{array}{l}4 \\
2 \\
2 \\
1 \\
-\end{array}$ \\
\hline
\end{tabular}


Outras espécies com alta freqüência, foram, Prionospio malmgreni, Heteromastus filiformis, Sigambra grubii, Armandia agilis, Magelona sp. e Capitella capitata.

Um número considerāvel de pequenas colônias de Diopatra $e f$. cuprea foi observado em toda a extensão da praia, principalmente na zona próxima à linha d'água. Foi calculada a biomassa também para esta espēcie, cuja importância decorre de seu volume e distribuição. o peso úmido de um indivíduo de porte mediano é de $0,710 \mathrm{~g}$ e o peso seco de 0,120 g. Para uma densidade média de 40 indivỉduos $/ \mathrm{m}^{2}$ na ärea de distribuição uniforme, a biomassa dessa espécie pode alcançar cerca de $28,40 \mathrm{~g} / \mathrm{m}^{2}$, (peso úmido).

Como elemento faunístico acessório, foi característica a presença, em quase todas as estações, de Anomalocardia brasiliana e Iphigenia brasiliensis, espécies que não são comuns nas demais praias da Enseada do Flamengo.

Como jā foi mencionado, a Praia do Saco da Ribeira apresenta um certo grau de poluição. Pelos resultados relativos à distribuição das espécies mais comuns (Fig. 4), pode ser constatada a existência de duas āreas distintas. Na primeira (Ārea A) onde estão localizadas as radiais I-IV, há um nūmero maior de espécies e de indíviduos. Na segunda (Ārea B), nas proximadades da indústria de pescado, abrangida pelas radiais V-VI, algumas espécies freqüentes na Ārea A, como Prionospio malmgreni, Magelona sp., Armandia agilis, praticamente não ocorrem; enquanto que outras como Heteromastus filiformis, Sigambra grubii e Laeonereis culveri, são encontradas em número considerável. o poliqueto Capitelza capitata, indicador de regiões poluídas, ocorreu com uma densidade razoavelmente alta na radial VI. Esta espécie é comum em áreas de despejo de residências, indústrias e fābricas de conservas (Reish 1955; 1973a). Ainda nesta área foi encontrada, embora em pequena quantidade, Podarke pallida, também considerada como organismo indicador de região poluída (Reish, 1973b).

A distribuição de Laeonereis culveri na praia, não está relacionada com o grau de poluição, mas com a baixa salinidade. Na Figura 4 pode ser constatada a relação entre a baixa salinidade nas estações 7-9 da radial I, e a ocorrência dessa espécie. De acordo com Mazurkiewcz (1970, cit.in: Pettibone, 1971), Laeonereis culveri é um dos anelídeos mais comuns na área de Alligator 
Harbor, Flórida, onde é encontrado entre os níveis médios das marés e no estuário de Mystic (Connecticut) onde ocorre em agregados na zona entre marés, alcançando até $10 \mathrm{~cm}$ de profundidade na areia fina e suportando variações de salinidade de $0,5-30 \%$. Pettibone (1971) faz ainda, referência à observação desse autor quanto ao tipo de alimentação de Laeonereis culveri, "deposit feeder" não seletivo, com fezes delgadas características, acumuladas na superfície do sedimento ao redor da abertura de seus tubos. Essas peculiaridades estão de acordo com as observadas na Praia do Saco da Ribeira. Na Figura 6 podem ser notados os depósitos de fezes, deixados na superfície do sedimento, em uma das áreas de maior concentração da espécie, radial I, Estações 7-9.

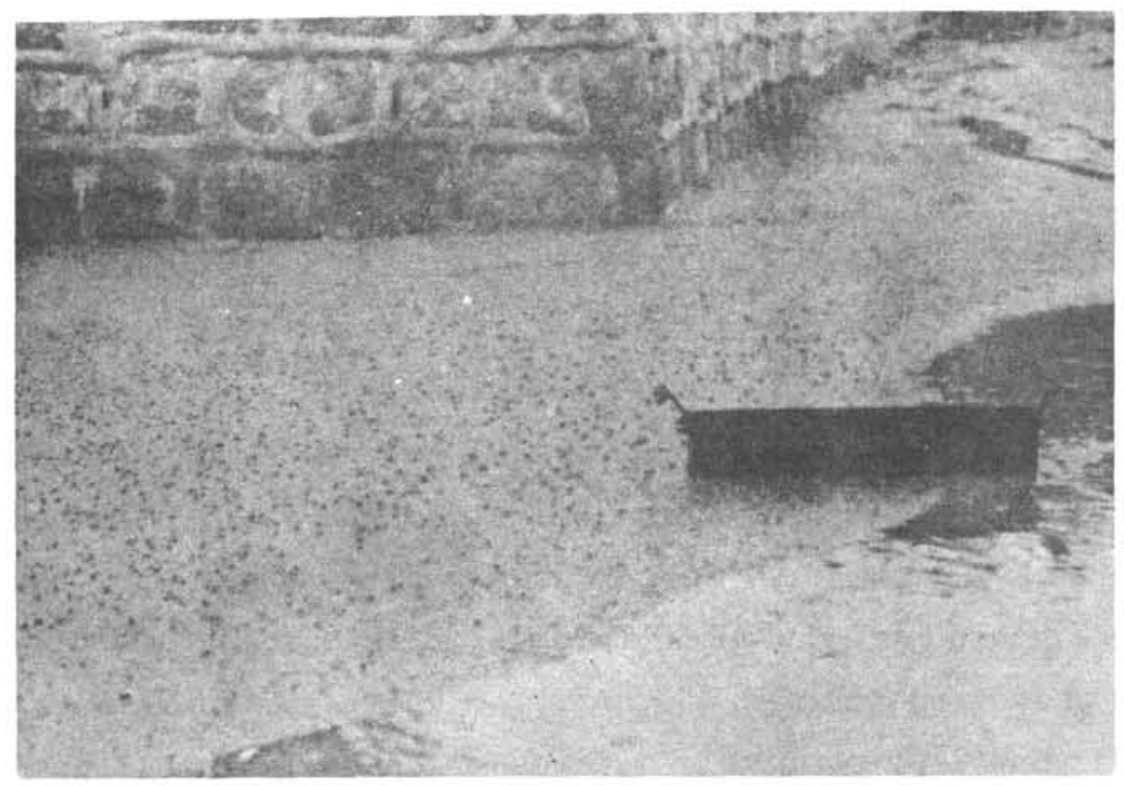

Fig. 6 - Aspecto dos depósitos fecais de Laeonereis culveri, na superfície do sedimento. Praia do Saco da Ribeira.

Os cursos de água doce, parecem ter influência também na distribuição das demais espécies. Nas radiais onde as estações não sofrem a influência de riachos ou onde estão mais próximas da água do mar, a salinidade variou entre $20-30 \%$, com uma ocorrência de espécies, relativamente homogênea em roda a extensão da praia. Nas estações onde a salinidade é inferior a $20 \%$, praticamente desaparecem Magelona sp., Heteromastus filiformis, Armandia agilis, Sigambra grubii e Prionospio malmgreni., aumentando gradativamente o número de Laeonereis culveri. 
Prionospio malmgreni parece ter preferência pelas regiões de maior embebição da praia, não ocorrendo nas estações situadas em níveis mais altos, como pode ser observado na radial IV (Fig. 4). Magelonasp. distribui-se por toda a região, estando melhor representada nos locais mais úmidos, ocorrendo o inverso com Armandia agilis. A maior ocorrência dessa espécie na Ārea A, parece estar relacionada com o alto conteúdo de matéria orgânica (Fig. 4).

\section{PRAIA DO CODÓ}

Considerações gerais - A Praia do Codóé uma continuação da Praia do Saco da Ribeira, estando localizada em uma área bem abrigada. É uma praia de areia 'grossa, com fundo lodoso em sua parte submersa. Como na Praia do Saco da Ribeira, uma parcela consideráv̆èl de seus sedimentos é de origem terrestre.

Resultados e discussão - As coletas foram efetuadas nos meses de novembro de 1973 e janeiro de 1975, com um total de 12 estações em 3 radiais. Os resultados da medida dos parâmetros físico-químicos, estão na Figura 7. A salinidade da āgua intersticial apresentou, na região mais alta la praia, valores muito inferiores aos $32-33 \%$ da ägua do mar. o teor de oxigênio dissolvido varia consideravelmente, alcançando valores de até 4,73 ml/1, em alguns pontos, caindo a $0,6 \mathrm{ml} / 1$ em outros. A temperatura manteve-se bastante estável, tanto para superfície do sedimento como a $15 \mathrm{~cm}$ de profundidade, oscilando entre $22-23^{\circ} \mathrm{C}$. Os valores de calcário são semelhantes aos da Praia do Saco da Ribeira e o teor de matéria orgânica oscilou entre 1-3\%. A anālise granulométrica, revelou a predominância de "areia grossa" (Fig. 8).

A Tabela III mostra a ocorrência e densidade dos poliquetos nesta praia. A fauna da região abaixo do nível mínimo da maré baixa, que só fica a descoberto excepcionalmente, é bem mais rica em poliquetos. Isto foi revelado pelos resultados da radial I, efetuada durante um período de baixa-mar excepcional. As coletas nessas estações proporcionaramalguns exemplares de várias espécies raras na região, como: Pseudeurythoë ambigua, Lumbrinereis paradoxa e Aricidea fauveli, nenhuma das quais encontradas em coletas posteriores. 


$$
\begin{aligned}
& \mathrm{mlO}_{2} / 1 \\
& \mathrm{mo}-\mathrm{CaCO}_{3} \%
\end{aligned}
$$
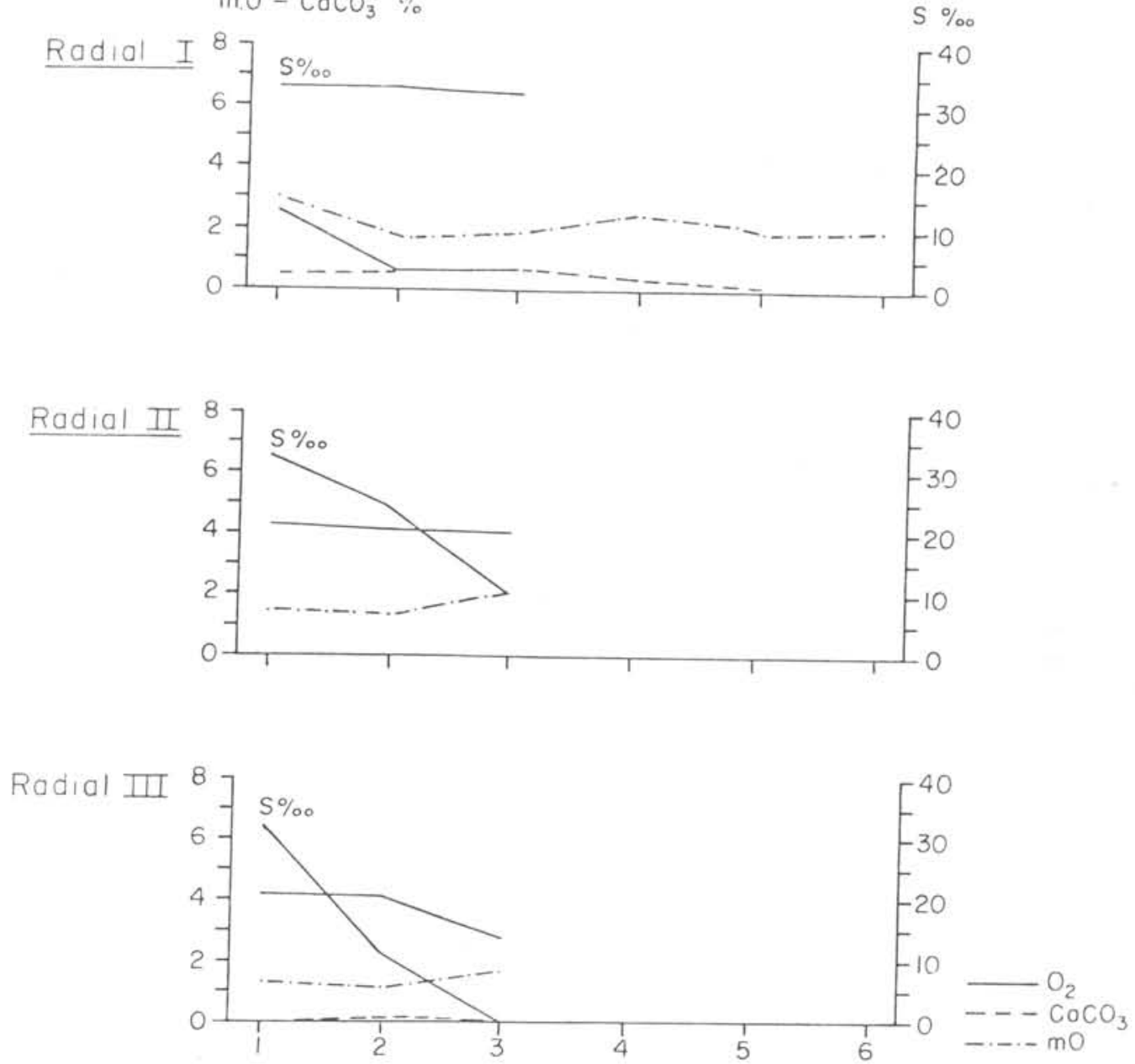

Fig. 7 - Distribuição de alguns parâmetros do sedimento e do ambiente intersticial na Praia do Codó.

\section{PRAIA DA ENSEADA}

Considerações gerais - A Praia da Enseada está localizada ao fundo da Enseada do Flamengo, com orientação leste-oeste, e tem uma largura média de $100 \mathrm{~m}$. A faixa recoberta pelas marés médias é de cerca de $30 \mathrm{~m}$, cortada por três pequenos cursos de água permanentes. Ê uma praia reta, plana, com aproximadamente $2 \mathrm{~km}$ de extensão e com acesso direto ao mar aberto, recebendo as vagas apenas atenuadas. 


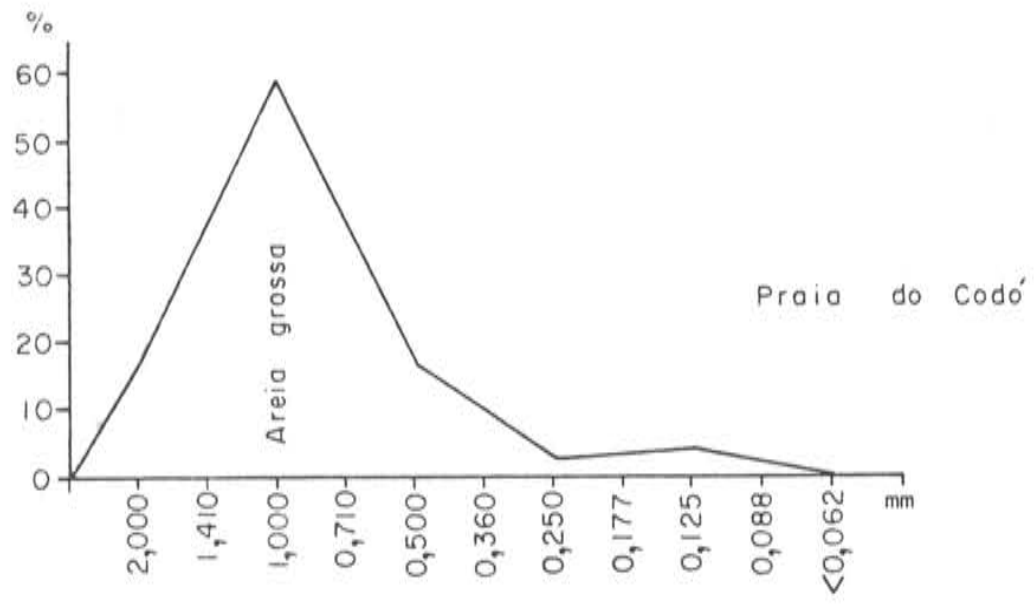

Fig. 8 - Gräfico da freqüência simples da distribuição granulomētrica.

TABELA III - Ocorrência das espēcies de poliquetos na Praia do Codō. Nümero de exemplares em amostras de $1 / 120 \mathrm{~m}^{2}$

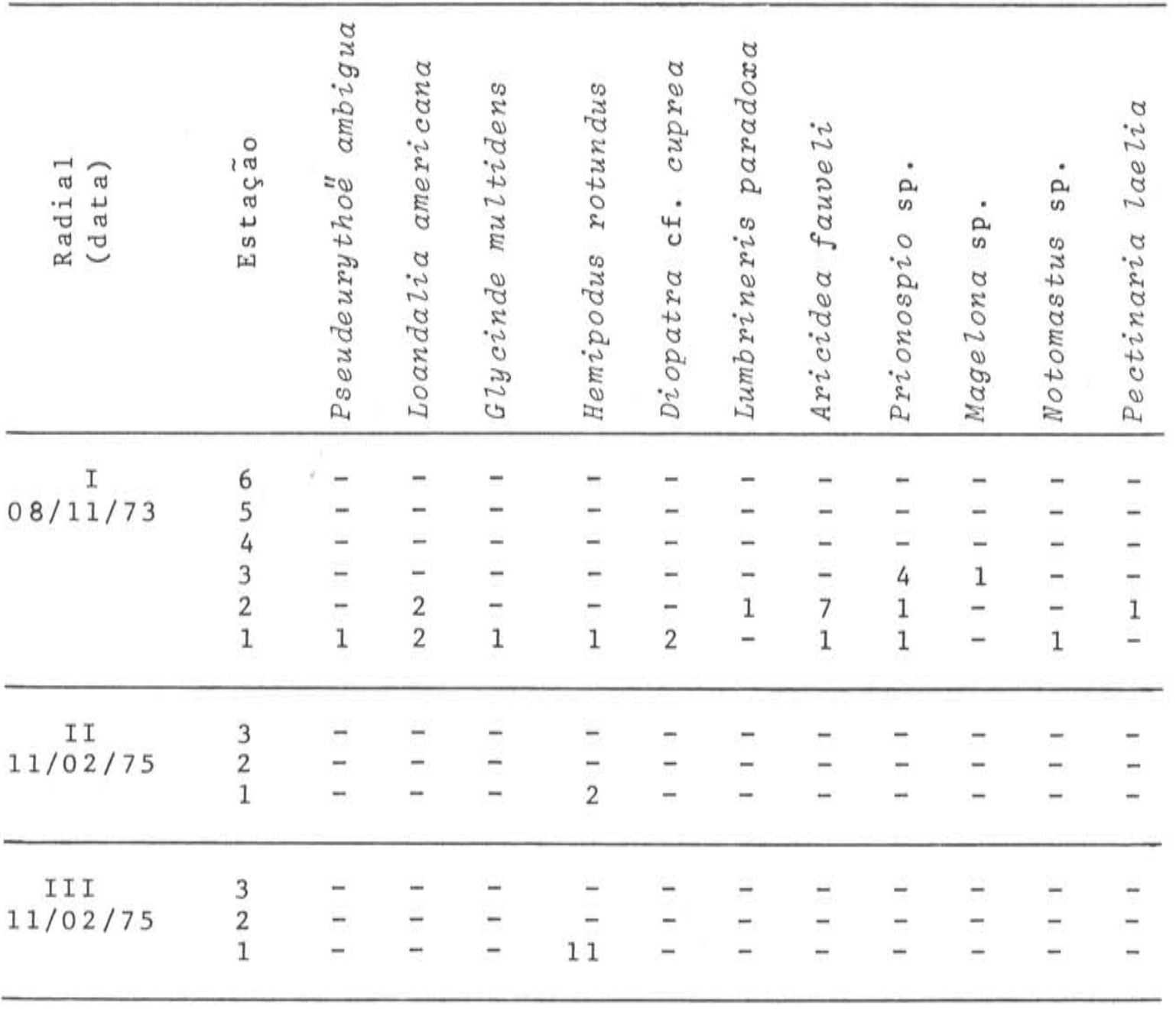


Atualmente, esta praia mostra os primeiros sinais de poluição provenient $\epsilon$ de esgotos domésticos. Essa condição é revelada pela intensa proliferação de flagelados clorofilados na superfície da praia. Ao longo dos ribeirões, que servem em ültima análise também para o escoamento dos esgotos residenciais, são visíveis largas manchas verdes revelando o alto grau de eutroficação da ärea.

Resultados e discussão - Na Praia da Enseada as coletas foram efetuadas nos meses de outubro e novembro de 1974 , com cinco radiais amostradas, totalizando 33 estações (Fig. 9). Os dados referentes às medidas dos parâmetros ambientais, estão reunidos na Tabela IV e Figura 10. As medidas de temperatura na superfície do sedimento e a $15 \mathrm{~cm}$ de profundidade não mostram grandes flutuações, alcançando valores um pouco mais elevados na zona de retenção nas regiões mais altas da praia. A salinidade da água do mar esteve entre $33-34 \%$. A salinidade da água intersticial variou de $29-34 \%$ na zona de saturação, alcançando valores mais baixos nas estações mais afastadas. Em algumas radiais a salinidade decresce gradativamente com o aumento da distância da linha d'água. Em outros casos, a salinidade no nível mais alto da praia foi praticamente nula $(2 \%$ ), como aconteceu na radial $\mathrm{V}$, pelo efeito de um dos

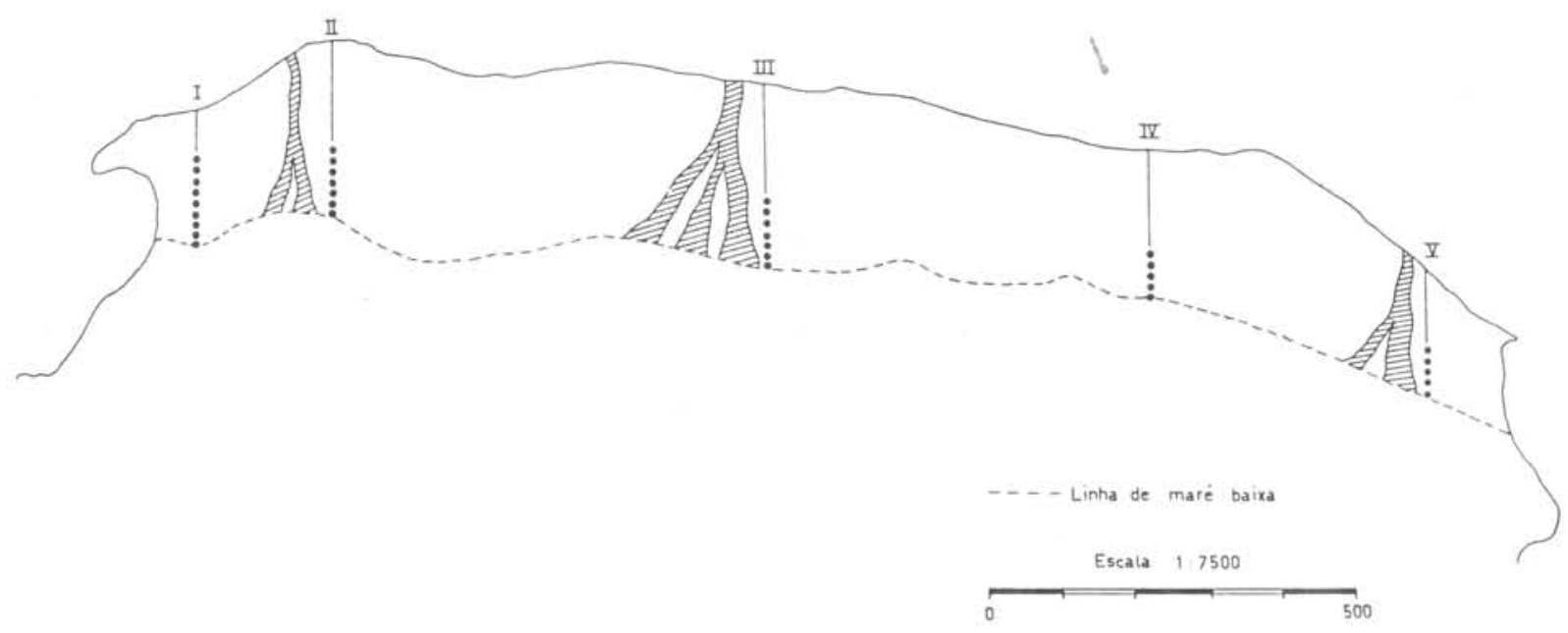

Fig. 9 - Praia da Enseada - Radiais com respectivos pontos de amostragem. 
cursos d'água existentes na praia. o conteúdo de oxigênio dissolvido na água intersticial manteve-se baixo durante todo o período de coleta, com maior número de estações onde os valores ficaram entre 0,40-0,90 ml/1. $0 \mathrm{pH}$ do sedimento permaneceu em torno de 7,0. A análise granulométrica revelou a predominância de sedimentos constituídos por partículas com diâmetro da ordem

TABELA IV - Dados físico-químicos das estações da Praia da Enseada

\begin{tabular}{|c|c|c|c|c|c|c|c|c|c|c|}
\hline \multirow{3}{*}{$\begin{array}{l}\text { Radial } \\
\text { (data) }\end{array}$} & \multirow{3}{*}{ Hora } & \multirow{3}{*}{$\begin{array}{l}\text { Local } \\
\text { de } \\
\text { coleta }\end{array}$} & \multirow{3}{*}{$\pi_{g u a}$} & \multicolumn{3}{|c|}{$\mathrm{T}\left({ }^{\circ} \mathrm{C}\right)$} & \multirow{3}{*}{$\begin{array}{c}s \\
(\% \circ 0)\end{array}$} & \multirow{3}{*}{$\begin{array}{c}\mathrm{O}_{2} \\
(\mathrm{~m} 1 / 1)\end{array}$} & \multirow{3}{*}{$\begin{array}{c}\mathrm{CaCO}_{3} \\
(\mathrm{z})\end{array}$} & \multirow{3}{*}{$\begin{array}{l}\text { Matéria } \\
\text { orgânica } \\
\quad(z)\end{array}$} \\
\hline & & & & $\mathbf{A r}$ & Sedi & ento & & & & \\
\hline & & & & & Sup. & Fund. & & & & \\
\hline I & $08: 15$ & 9 & - & 21,9 & 26,0 & 22,9 & 08,00 & 1,01 & 9,60 & 0,80 \\
\hline \multirow{9}{*}{$13 / 10 / 74$} & - & 8 & - & 21,6 & 24.7 & 21,9 & 09,60 & 0.50 & 13,60 & 0,80 \\
\hline & - & 7 & - & 22,2 & 24,0 & 22,2 & 10,10 & 0,50 & 11,20 & 1,20 \\
\hline & - & 6 & - & 22.0 & 24,2 & 21,9 & 20,10 & 0,45 & 3,10 & 0,90 \\
\hline & - & 5 & - & 22,8 & 23,9 & 22,0 & 16,70 & 0,50 & 5,60 & 0,90 \\
\hline & - & 4 & - & 21,8 & 23.6 & 22,0 & 33,20 & 0,50 & 4,00 & 1,10 \\
\hline & - & 3 & - & 21,7 & 22,7 & 22,3 & 33,40 & 0,73 & 6,00 & 0,70 \\
\hline & - & 2 & - & 20,7 & 22,8 & 22,4 & 34,20 & 0,77 & 3,10 & 0,90 \\
\hline & - & 1 & - & 20,8 & 22,5 & 22,7 & 34,10 & $0, y 6$ & 3,80 & 1,00 \\
\hline & $07: 00$ & Mar & 22,4 & 20,8 & - & - & 33,60 & 4,20 & - & - \\
\hline II & $07: 45$ & 7 & - & 23,6 & 24,0 & 23,3 & - & - & 3,30 & 0,60 \\
\hline \multirow[t]{7}{*}{$28 / 10 / 74$} & - & 6 & - & 23,6 & 24,1 & 23,3 & 11.00 & 0,63 & 2,90 & 0,50 \\
\hline & - & 5 & - & 23,4 & 24,0 & 23,3 & 11,00 & 0,63 & 4,20 & 0,80 \\
\hline & - & 4 & - & 23,4 & 24,0 & 23,2 & 12,70 & 0,57 & 5,50 & 0,90 \\
\hline & - & 3 & - & 23,4 & 24,0 & 23,2 & 14,50 & 0,41 & 6,90 & 1,00 \\
\hline & - & 2 & - & 23,4 & 24,0 & 23,3 & 33,50 & 0.59 & 7,50 & 1,10 \\
\hline & - & 1 & - & 23,3 & 24,0 & 23,3 & 34,30 & 0,71 & 7,30 & 0,90 \\
\hline & $06: 40$ & Mar & 23,3 & 23,4 & - & - & 34,90 & 4,50 & - & - \\
\hline \multirow{8}{*}{$\begin{array}{l}\text { III } \\
29 / 10 / 74\end{array}$} & $08: 30$ & 7 & - & 24,0 & 24,0 & 24,0 & - & - & 1,80 & 0,00 \\
\hline & - & 6 & - & 24,0 & 24,0 & 24,5 & 27,50 & 0,52 & 1,20 & 0,20 \\
\hline & - & 5 & - & 24,0 & 24,0 & 24,0 & 20,05 & 0,63 & 1,30 & 0,20 \\
\hline & - & 4 & - & 24,5 & 24,0 & 23,5 & 27,18 & 0,31 & 1,30 & 0,20 \\
\hline & - & 3 & - & 24,0 & 24,3 & 23.5 & 27,18 & 0,84 & 1,60 & 0,20 \\
\hline & - & 2 & - & 24,0 & 24,0 & 23,3 & 24,25 & $2: \div 4$ & 1,50 & 0,10 \\
\hline & - & 1 & - & 24,0 & 24,0 & 23,5 & 29,00 & 2,65 & 2,40 & 0,00 \\
\hline & $07: 30$ & Mar & 24,0 & 24,0 & - & - & 34,25 & 4,62 & - & - \\
\hline \multirow{6}{*}{$\stackrel{\text { IV }}{13 / 11 / 74}$} & $08: 00$ & 5 & - & 19.0 & 20,0 & 21,5 & - & - & 1,80 & 0,00 \\
\hline & - & 4 & - & 18,5 & 20,0 & 21,5 & - & - & 1,20 & 0,00 \\
\hline & - & 3 & - & 18,5 & 21,5 & 21,5 & - & - & 1,70 & 0,00 \\
\hline & - & 2 & - & 18,5 & 22.0 & 21,5 & 13,50 & 0.45 & 1,00 & 0,00 \\
\hline & - & 1 & - & 18,5 & 22,0 & 21,5 & 33,00 & 0,50 & 1,10 & 0.00 \\
\hline & $07: 30$ & Mar & 23,0 & 20,0 & - & - & 34,00 & 4,47 & - & 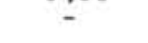 \\
\hline v & $08: 45$ & 5 & - & 22,5 & 24,0 & 23,5 & 02,00 & 0,41 & 0,80 & 0,30 \\
\hline \multirow[t]{5}{*}{$12 / 11 / 74$} & - & 4 & - & 22,5 & 24,0 & 23,5 & 14,00 & 0,00 & 1,60 & 0,00 \\
\hline & - & 3 & - & 22,0 & 23,5 & 23,5 & 25,50 & 0,00 & 0,00 & 0,30 \\
\hline & - & 2 & - & 22,0 & 23,5 & 23,5 & 25,50 & 0.31 & 1,00 & 0,10 \\
\hline & - & 1 & - & 22,0 & 23,0 & 23,5 & 34,00 & 0,50 & 1,00 & 0,30 \\
\hline & $08: 00$ & Mar & 23,0 & 23,0 & . & (2) & 34,00 & 4,47 & - & - \\
\hline
\end{tabular}



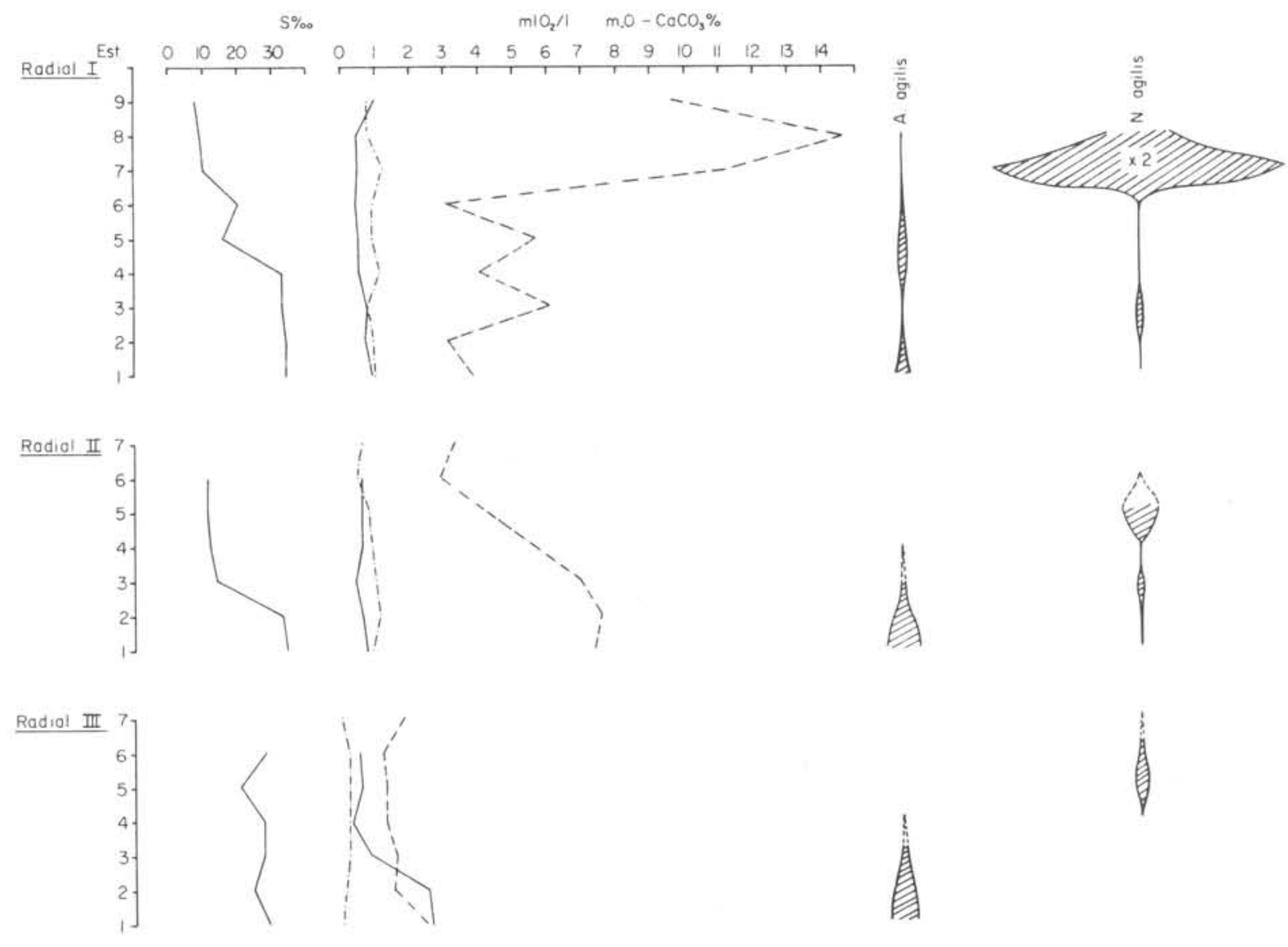

Rodial IV 5

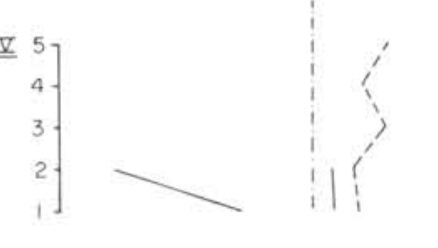

基
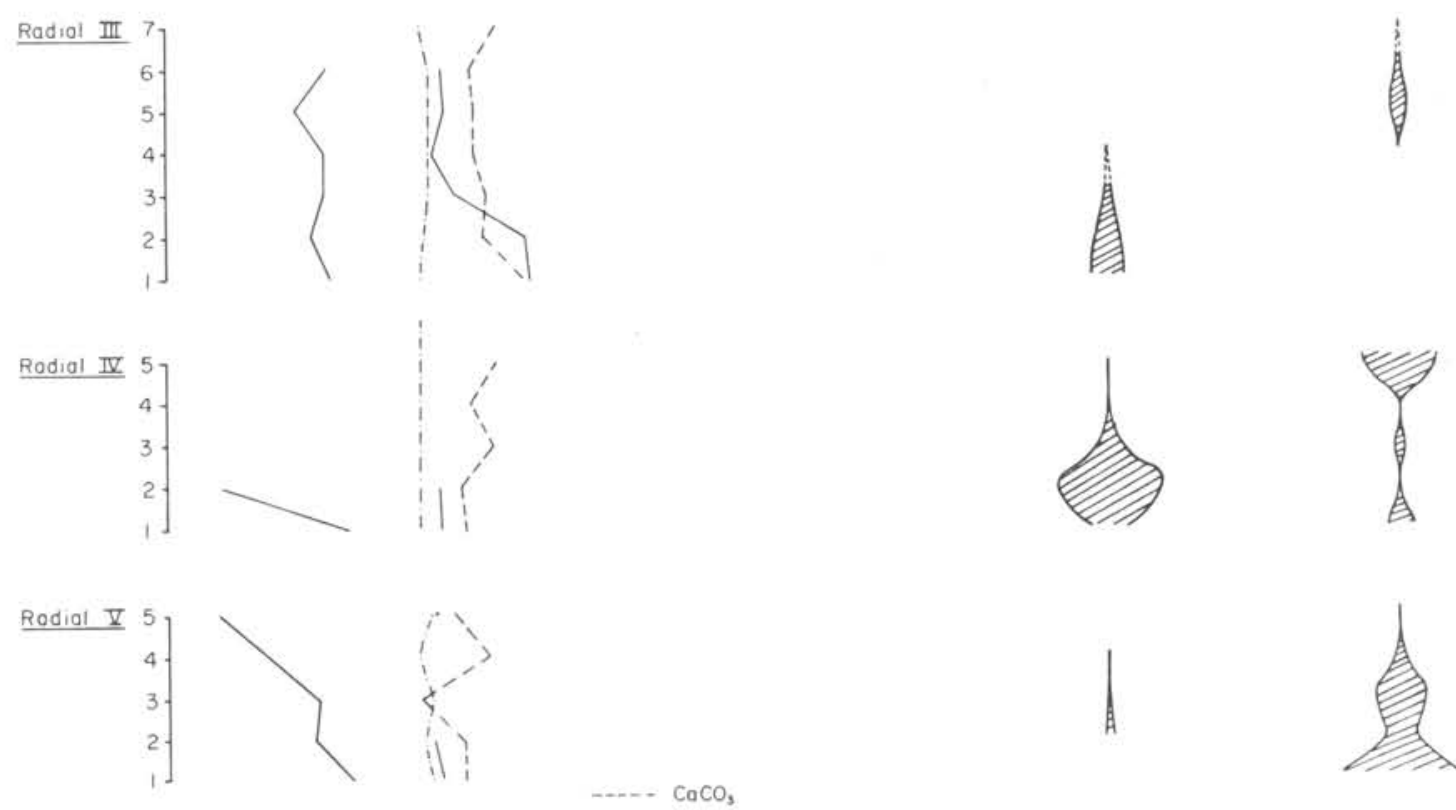

Fig. 10 - Distribuição horizontal de alguns parâmetros ambientais e das espécies de poliquetos mais importantes, em relação a $1120 \mathrm{~m}^{2}$, nas 5 radiais amostradas para a Praia da Enseada. As estações de n? 1 estão localizadas junto à linha d'água. 
de $0,125 \mathrm{~mm}$, característico de "areia muito fina" (Fig. 11). 0 conteúdo de calcário foi bastante alto em relação às demais praias estudadas, variando entre 3-13\%. 0 possível responsável por estes altos valores em calcário é a riqueza em fragmentos de conchas. Tal hipótese pode ser justificada pela abundância de Donax sp., constatada durante a triagem do material, especialmente nas amostras das radiais I-II, onde o teor de calcário é o mais elevado. 0 conteúdo de matēria orgânica foi bastante baixo, variando entre 0,2-1\%, como tambëm assinalado por Nonato (1958).

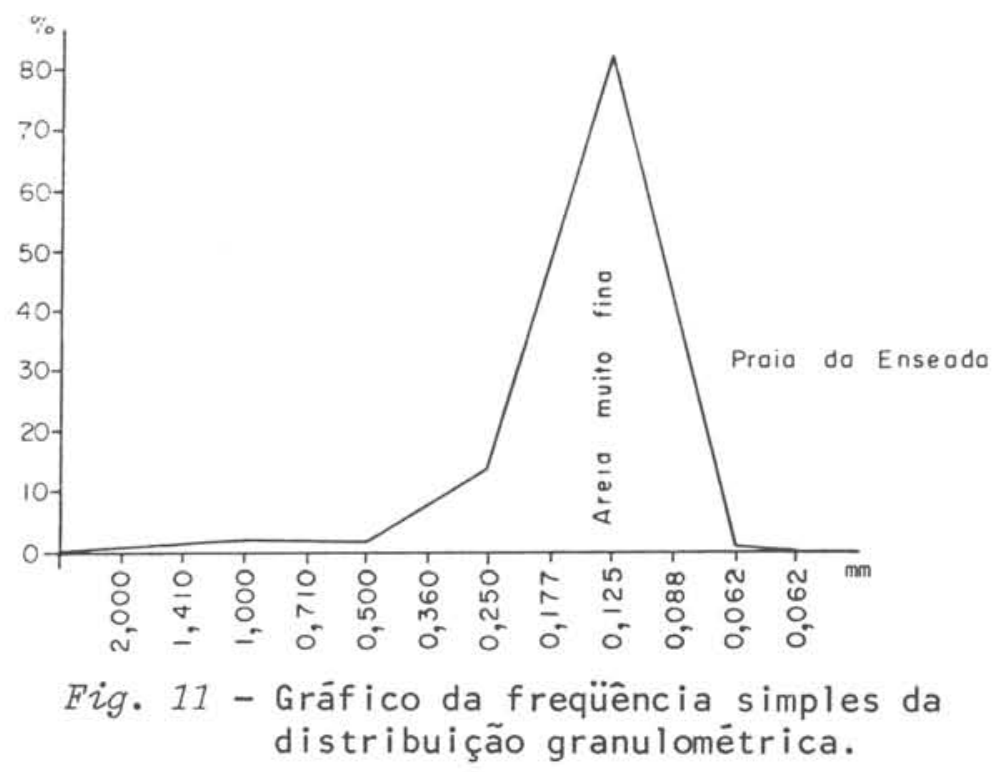

Como pode ser observado pela Tabela V e Figura 10, na Praia da Enseada não foi encontrada uma grande diversidade de espécies. As espécies dominantes nesta praia foram: Nerine agilis, numericamente mais importante e Armandia agilis. Outras, como Diopatra of. cuprea, Nephtys caeca e Hemipodus rotundus foram encontradas na região saturada da praia, e em menor número. Arenicola brasiliensis está presente na faixa ao longo da linha da maré média, embora não seja mencionada na Tabela V (na qual são referidas apenas as espécies presentes nas amostras obtidas com o delimitador).

A fauna total da praia é pobre, ocorrendo como organismo característico Balanoglossus clavigerus, simultaneamente com Arenicola brasiliensis. Foi ainda registrada a ocorrência de Terebra cinerea e Donax sp., nas primeiras estações.

A natureza do substrato parece favorecer a permanência de Nerine agilis, 
TABELA V - Ocorrência das espécies de poliquetos na Praia da Enseada. Número de exemplares em amostras de $1 / 20 \mathrm{~m}^{2}$

\begin{tabular}{|c|c|c|c|c|c|c|c|c|}
\hline 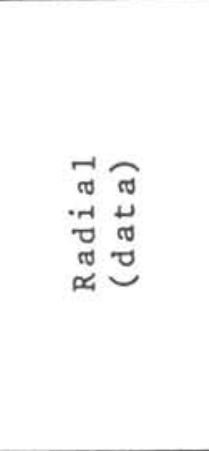 & 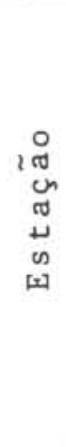 & $\begin{array}{l}0 \\
0 \\
0 \\
0 \\
0 \\
0 \\
0 \\
0 \\
0 \\
0 \\
0 \\
0 \\
0 \\
0 \\
z\end{array}$ & 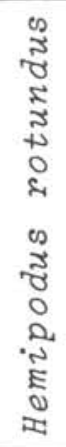 & 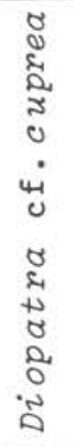 & 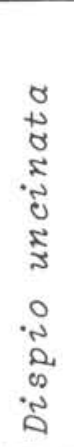 & 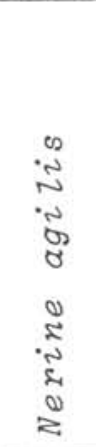 & 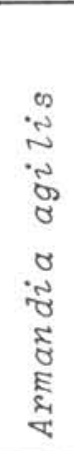 & 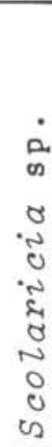 \\
\hline I & 9 & - & - & - & - & - & - & - \\
\hline $13 / 10 / 74$ & $\begin{array}{l}8 \\
7 \\
6 \\
5 \\
4 \\
3 \\
2 \\
1\end{array}$ & $\begin{array}{l}- \\
- \\
- \\
- \\
- \\
1 \\
2 \\
2\end{array}$ & $\begin{array}{l}- \\
\overline{-} \\
\overline{-} \\
\overline{-} \\
\overline{-}\end{array}$ & $\begin{array}{l}- \\
- \\
- \\
- \\
- \\
- \\
- \\
1\end{array}$ & $\begin{array}{l}- \\
- \\
- \\
- \\
- \\
- \\
- \\
1\end{array}$ & $\begin{array}{r}38 \\
342 \\
- \\
-1 \\
- \\
2 \\
-\end{array}$ & $\begin{array}{l}- \\
1 \\
- \\
2 \\
3 \\
1 \\
2 \\
6\end{array}$ & $\begin{array}{l}- \\
- \\
- \\
- \\
- \\
- \\
-\end{array}$ \\
\hline $\begin{array}{c}\text { II } \\
28 / 10 / 74\end{array}$ & $\begin{array}{l}7 \\
6 \\
5 \\
4 \\
3 \\
2 \\
1\end{array}$ & $\begin{array}{l}- \\
\overline{-} \\
\overline{-} \\
\overline{2} \\
\overline{2}\end{array}$ & $\begin{array}{l}- \\
- \\
- \\
1 \\
- \\
- \\
-\end{array}$ & $\begin{array}{l}- \\
- \\
- \\
- \\
- \\
-\end{array}$ & $\begin{array}{l}- \\
- \\
- \\
- \\
- \\
-\end{array}$ & $\begin{array}{l}- \\
- \\
19 \\
1 \\
2 \\
- \\
-\end{array}$ & $\begin{array}{r}- \\
- \\
- \\
- \\
2 \\
9 \\
20\end{array}$ & $\begin{array}{l}- \\
- \\
- \\
- \\
\\
-\end{array}$ \\
\hline $\begin{array}{c}\text { III } \\
29 / 10 / 74\end{array}$ & $\begin{array}{l}7 \\
6 \\
5 \\
4 \\
3 \\
2 \\
1\end{array}$ & $\begin{array}{l}- \\
\overline{-} \\
\overline{-} \\
\overline{-} \\
-\end{array}$ & $\begin{array}{l}- \\
\overline{-} \\
\overline{-} \\
- \\
- \\
-\end{array}$ & $\begin{array}{l}\overline{-} \\
\overline{-} \\
\overline{-} \\
- \\
\overline{-}\end{array}$ & $\begin{array}{l}- \\
- \\
- \\
- \\
- \\
2\end{array}$ & $\begin{array}{l}- \\
2 \\
6 \\
1 \\
- \\
- \\
-\end{array}$ & $\begin{array}{r}- \\
- \\
- \\
- \\
4 \\
9 \\
16\end{array}$ & $\begin{array}{l}- \\
- \\
- \\
\overline{-} \\
-\end{array}$ \\
\hline $\begin{array}{c}\text { IV } \\
13 / 11 / 74\end{array}$ & $\begin{array}{l}5 \\
4 \\
3 \\
2 \\
1\end{array}$ & $\begin{array}{l}- \\
- \\
- \\
-\end{array}$ & $\begin{array}{l}- \\
\overline{-} \\
-\end{array}$ & $\begin{array}{l}- \\
- \\
- \\
-\end{array}$ & $\begin{array}{l}- \\
- \\
- \\
-\end{array}$ & $\begin{array}{r}36 \\
1 \\
4 \\
1 \\
7\end{array}$ & $\begin{array}{r}1 \\
1 \\
7 \\
51 \\
18\end{array}$ & $\begin{array}{l}- \\
- \\
- \\
-\end{array}$ \\
\hline $\begin{array}{c}V \\
12 / 11 / 74\end{array}$ & $\begin{array}{l}5 \\
4 \\
3 \\
2 \\
1\end{array}$ & $\begin{array}{l}- \\
- \\
- \\
-\end{array}$ & $\begin{array}{l}\text { - } \\
- \\
-\end{array}$ & $\begin{array}{l}- \\
- \\
- \\
-\end{array}$ & $\begin{array}{l}- \\
- \\
- \\
-\end{array}$ & $\begin{array}{r}1 \\
3 \\
24 \\
14 \\
56\end{array}$ & $\begin{array}{l}- \\
1 \\
1 \\
2 \\
-\end{array}$ & $\begin{array}{l}- \\
- \\
- \\
-\end{array}$ \\
\hline
\end{tabular}


espécie dominante na zona do médio litoral. Esta espécie, provavelmente, tem preferência por sedimentos mais finos, como os que aî ocorrem. Nerine agilis parece possuir um alto grau de tolerância às variações de salinidade, pois suas maiores concentrações ocorrem na radial I, Estações 7-8 e na V, Estação 1 , onde os valores variaram des de $8 \%$ nas primeiras até $34 \%$ na segunda.

As observações mencionadas em relação a Diopatra cf. cuprea e Arenicola brasiliensis na Praia da Enseada, por Nonato (1958), concordam com as feitas durante este trabalho. As primeiras linhas de colônias de Diopatra coincidem com o nível alcançado pelas marés médias. A densidade média de Arenicola é aproximadamente 5 animais $/ \mathrm{m}^{2}$, não sendo aparente qualquer tendência a agrupamento. A profundidade a que atingem os vermes varia entre $40 \mathrm{~cm}$ para os , exemplares maiores e 5-10 cm para os jovens. Sendo a praia muito regular, a 'profundidade alcançada está quase exclusivamente em função do tamanho do animal. Esta espécie se reproduz, na Praia da Enseada, durante todo o ano (Nonato, 1958), sendo que as massas gelatinosas das desovas foram encontradas em grande número, em novembro; cada uma não ultrapassando $20 \mathrm{~cm}$ de comprimento (Fig. 12). Segundo Nonato (1958), a maior freqüência de desovas ocorre de novembro a maio.

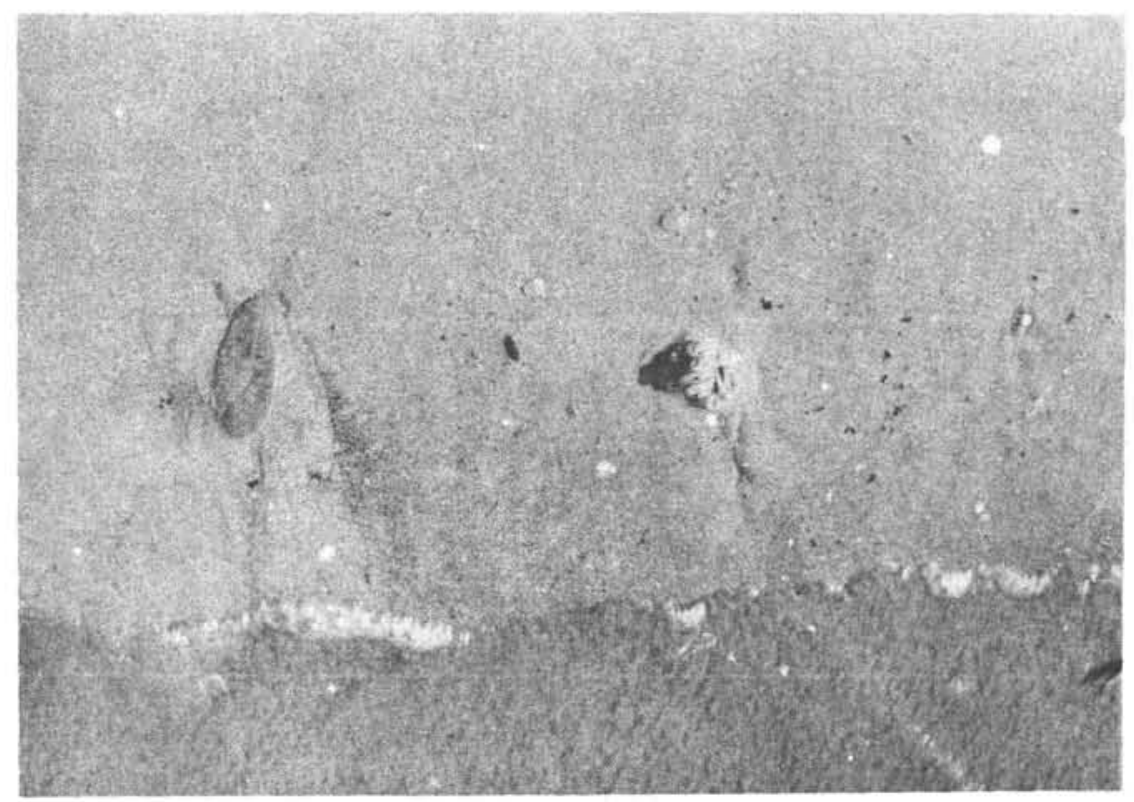

Fig. 12 - Detalhe da abertura do tubo e desova de Arenicola brasiliensis. Praia da Enseada. 
Armandia agizis e Nephtys caeca parecem ter preferência pelas regiões mais úmidas da praia, praticamente desaparecendo na região mais seca.

\section{PRAIA DO PEREQUÊ-MIRIM}

Considerações gerais - A Praia do Perequê-Mirim tem direção aproximadamente leste-oeste, estando aberta para o mar e exposta às vagas. Apresenta um suave gradiente de declividade em seu canto leste (Ārea B), o declive aumentando em direção ao centro da praia. A maior distância entre a linha de baixa-mar e o jundu está localizada no canto leste (Área B), com uma amplitude de aproximadamente $84 \mathrm{~m}$, como pode ser observado na Figura 13.

A estratificação dos sedimentos é bem marcada, especialmente na extremidade oeste (Ārea A), onde o declive é mais acentuado. Nos pontos extremos da praia há riachos que podemser considerados insignificantes, devido ao pequeno volume d'água que transportam. Em vários pontos da praia foram observados afloramentos de água doce, em geral nas regiões mais afastadas da linha d'água e, atē mesmo em āreas normalmente submersas.

Apesar das numerosas residências contíguas à praia, não foram observados sinais de poluição de origem urbana.

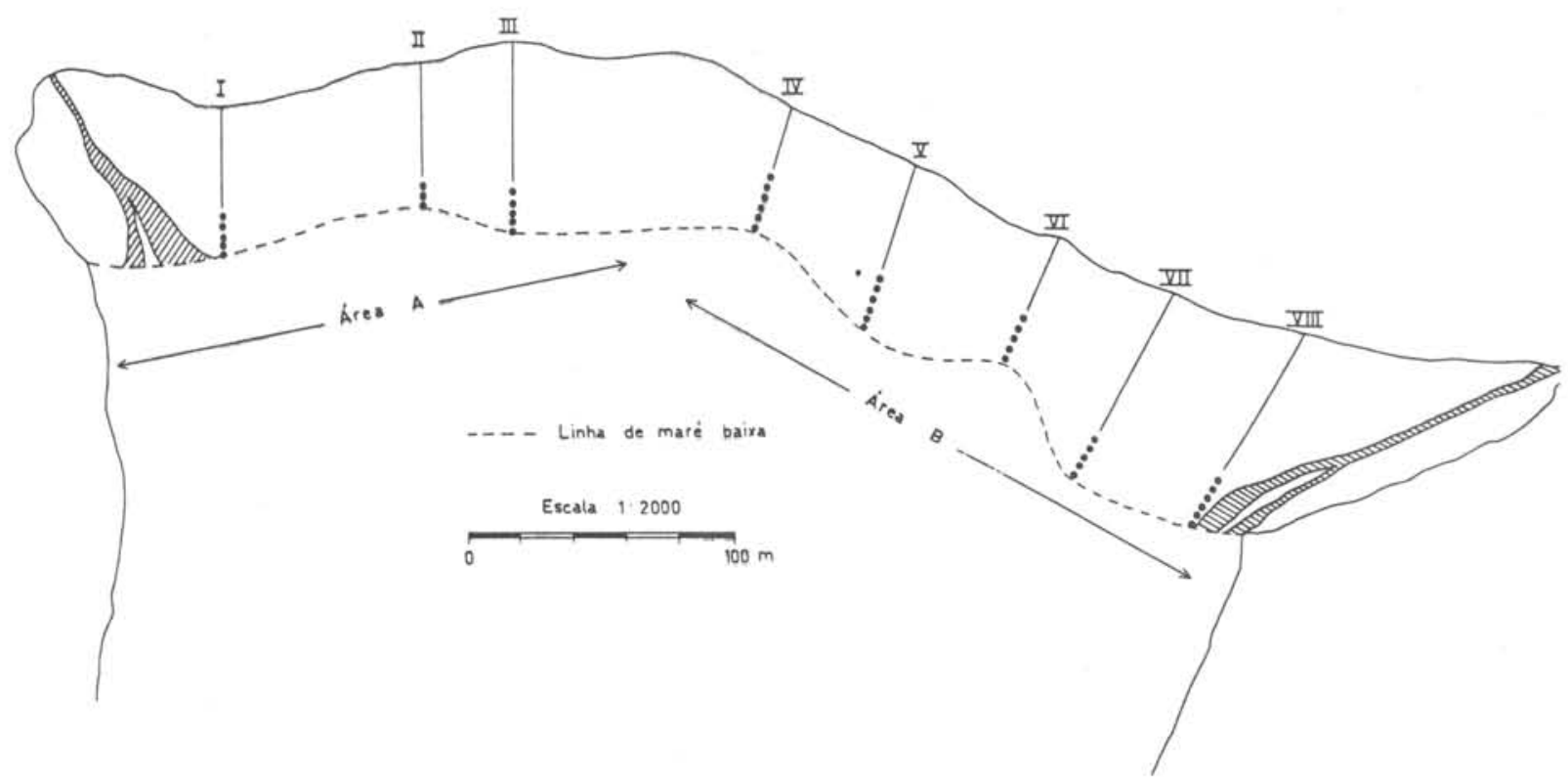

Fig. 13 - Praia do Perequê-Mirim.

Radiais com respectivos pontos de amostragem. 
Resultados e discussão - Foram efetuadas de março a junho de 1974, 8 1inhas de amostragem, com um total de 41 estações (Figura 13). Além dessas estações regulares foram feitas algumas coletas na extremidade leste da praia, em locais próximos às rochas do costão. Os dados referentes às medidas de temperatura, salinidade, oxigênio, matēria orgânica e calcārio estão reunidos na Figura 14. A temperatura dos sedimentos recém-descobertos, aproxima-se da-
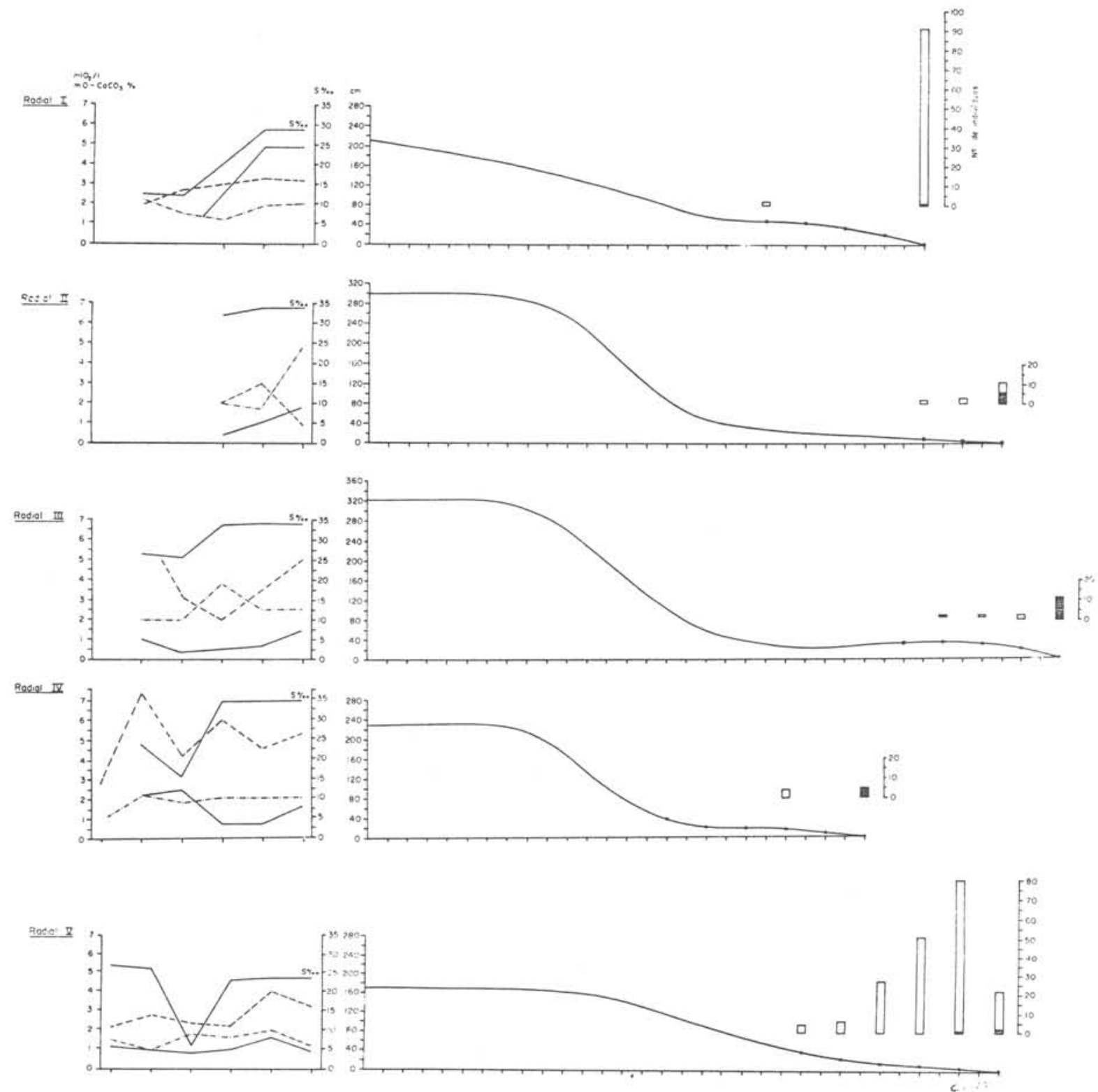

Fig. 14 - Distribuição de alguns parâmetros ambientais e abundância das espécies de poliquetos na Praia do Perequê-Mirim. Perfis das transversais I a VIII. As estações de n? l estão junto à linha d'água. 

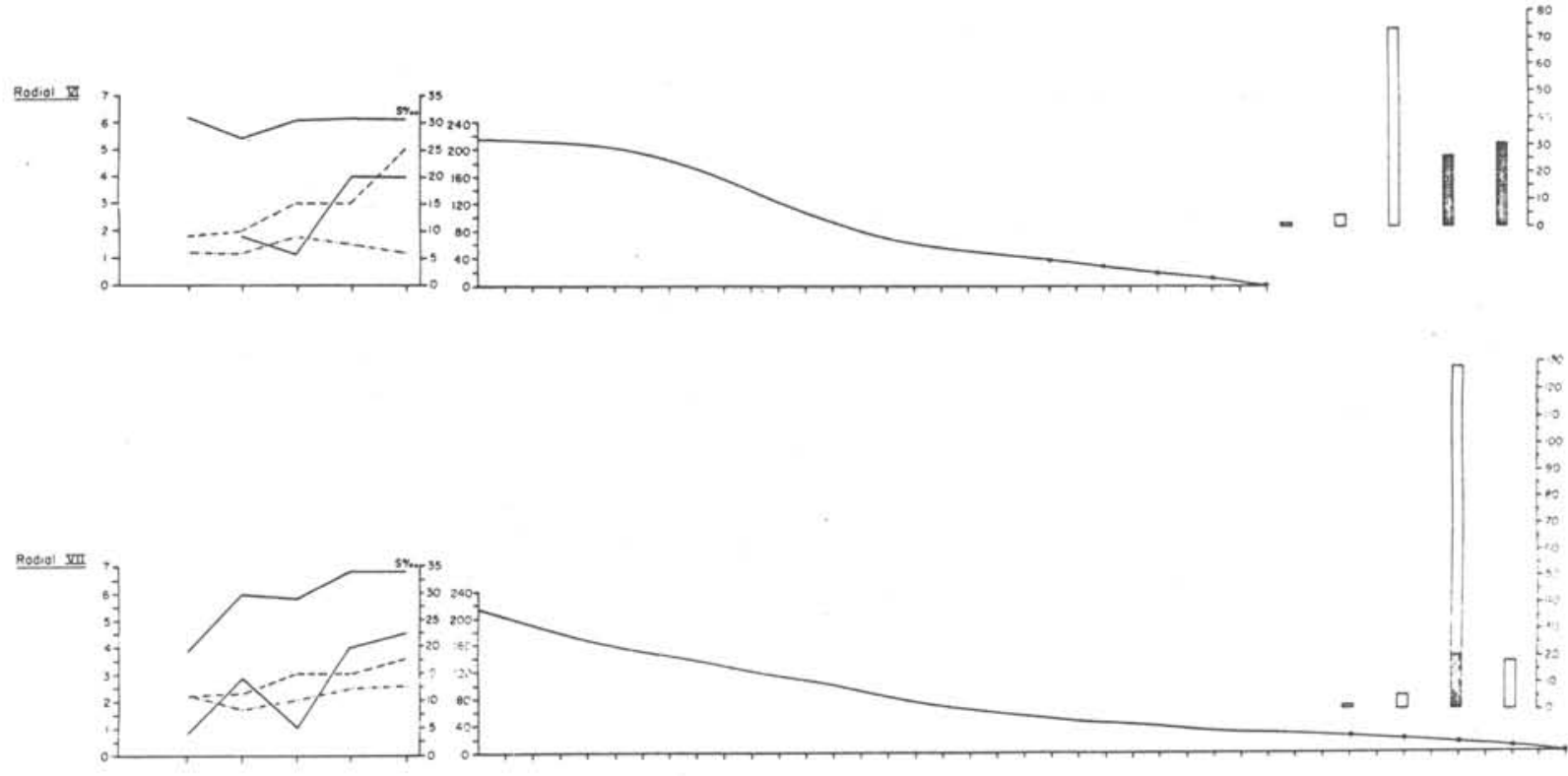

Rosial Im

- o,

...no

DNerine agilis

Diopatra of. ouprea

$\checkmark$ Amandia agilis

- Perinereis melanocephala

Divera americana

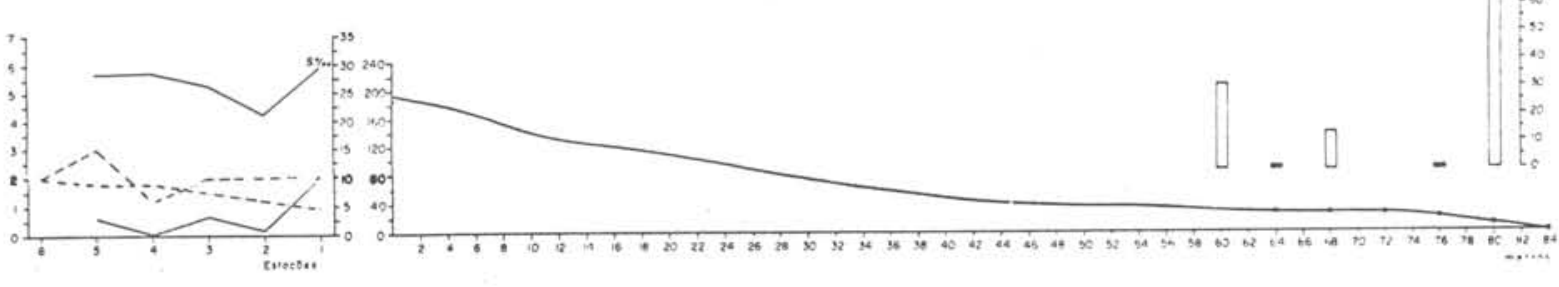

Fig. 14 - Distribuição de alguns parâmetros ambientais e abundância das espécies de poliquetos na Praia do Perequê-Mirim. Perfis das transversais I. a VIII. As estações de no l estão junto à linha d'ägua.

quela do mar, porém, na zona exposta por um período maior alcança os valores mais altos. A $15 \mathrm{~cm}$ de profundidade a temperatura é em geral mais baixa que a da superfície. A salinidade da água do mar variou entre $30-34 \%$, predominando os valores mais elevados. A salinidade da água intersticial aproxima-se da do mar; sofrendo algumas quedas bruscas, devido aos afluxos de água doce localizados ao alto da praia, como ocorre nas Estações I.4-5; IV.4; V.4 e VI.5 (o algarismo romano indicando a radial) (Fig. 14). Os valores de oxigênio dissolvido são razoavelmente baixos, com pequenas flutuaçöes e semelhante aos 
da Praia da Enseada. As características do sedimento, constatadas visualmente, foram confirmadas pela anālise granulométrica. Ao longo da linha de baixa-mar os sedimentos são mais finos e compactos, passando rapidamente a areia grossa, ao nîvel da linha de maré alta. Em algumas āreas, o sedimento fino é recoberto por areia grossa, proveniente dos níveis superiores. A porosidade, avaliada para os locais onde há maior número de espécies, variou entre 40-50\%; resultados estes comparáveis aos de Amoureux (1966). o conteüdo de calcário e matéria orgânica ficou respectivamente entre $1-7,5 \%$ e $1-4,8 \%$. Os valores de matêria orgânica foram os mais altos em relação às demais praias estudadas.

Os dados referentes à ocorrência e densidade dos poliquetos nesta praia são apresentados na Tabela VI e Figura 14. A espécie dominante foi Nerine agilis. Nos locais contíguos às rochas do costão, constatou-se uma densidade muito alta para essa espécie, alcançando 205 exemplares em $1 / 20 \mathrm{~m}^{2}$, o que corresponde a cerca de 4.000 indivíduos $/ \mathrm{m}^{2}$.

A segunda espécie mais abundante foi Diopatra cf. cuprea com grande número de colônias compactas que podem ser observadas na zona inferior da praia. Além dessas espécies foram encontradas, esporadicamente, Armandia agilis, Glycera americana e Perinereis melanocephala. A ocorrência das duas primeiras é coerente com o nível das marés e com o tipo de substrato predominante. Quanto às duas ûltimas, das quais se obteve apenas um exemplar de cada, pa-. recem constituir ocorrência acidental.

Como elemento faunístico acessōrio, foi característica a presença, em determinadas estações, de um nümero considerävel de Donax sp. e Terebra cinerea.

Pela plotagem dos resultados das análises granulométricas no diagrama de Shepard (Fig. 15), verificou-se que a grande maioria das amostras proveio de uma faixa de areia fina e muito fina e um menor número, de áreas com porcentagem mais elevada de areia grossa, onde as espécies mencionadas năo ocorrem em número significativo. Uma estreita correlação pode ser observada entre a distribuição e densidade da espécie dominante, Nerine agilis e a granulometria, sendo que nos locais de areia mais fina é encontrado um maior número de indivíduos. Fica assim demonstrado uma certa preferência da espécie pelo 
TABELA VI - Ocorrência das espēcies de poliquetos na Praia do Perequê-Mirim. Número de exemplares em amostras de $1 / 20 \mathrm{~m}^{2}$

\begin{tabular}{|c|c|c|c|c|c|c|}
\hline 可 & 怘 & 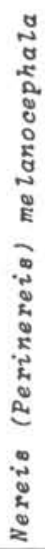 & 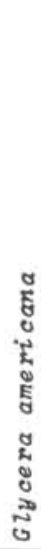 & 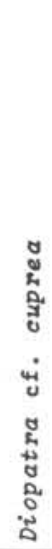 & 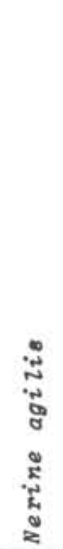 & 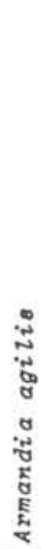 \\
\hline$\underset{22 / 06 / 74}{I}$ & $\begin{array}{l}5 \\
4 \\
3 \\
2 \\
1\end{array}$ & $\begin{array}{l}\bar{z} \\
\overline{1}\end{array}$ & $\begin{array}{l}\bar{z} \\
\bar{z}\end{array}$ & $\begin{array}{l}\overline{-} \\
\overline{-} \\
\overline{-}\end{array}$ & $\begin{array}{l}{ }^{2} \\
= \\
90\end{array}$ & $\begin{array}{l}\bar{z} \\
\overline{-}\end{array}$ \\
\hline $\begin{array}{c}\text { II } \\
20 / 06 / 74\end{array}$ & $\begin{array}{l}3 \\
2 \\
1\end{array}$ & $\bar{z}$ & - & $\overline{6}$ & $\begin{array}{l}2 \\
3 \\
5\end{array}$ & $\overline{-}$ \\
\hline $\operatorname{IIII}_{20 / 06 / 74}$ & $\begin{array}{l}5 \\
4 \\
3 \\
2 \\
1\end{array}$ & $\begin{array}{l}z \\
z \\
z\end{array}$ & $\begin{array}{l}\bar{z} \\
\bar{z}\end{array}$ & $\begin{array}{l}\overline{-} \\
\overline{11}\end{array}$ & $\begin{array}{r}- \\
1 \\
2 \\
-\end{array}$ & $\begin{array}{l}\overline{-} \\
\overline{-}\end{array}$ \\
\hline $\begin{array}{c}\text { IV } \\
19 / 06 / 74\end{array}$ & $\begin{array}{l}6 \\
5 \\
4 \\
3 \\
2 \\
1\end{array}$ & 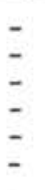 & $\bar{z}$ & $\begin{array}{l}\overline{-} \\
\overline{5} \\
\overline{5}\end{array}$ & $\begin{array}{l}= \\
= \\
- \\
-\end{array}$ & $\begin{array}{l}\bar{z} \\
\overline{-} \\
\bar{z}\end{array}$ \\
\hline$\frac{v}{18 / 06 / 74}$ & $\begin{array}{l}6 \\
5 \\
4 \\
3 \\
2 \\
1\end{array}$ & $\begin{array}{l}\bar{z} \\
\bar{z} \\
z\end{array}$ & $\begin{array}{l}\bar{z} \\
\bar{y} \\
\overline{-}\end{array}$ & $\begin{array}{l}- \\
\overline{5} \\
-\end{array}$ & $\begin{array}{r}4 \\
6 \\
27 \\
51 \\
79 \\
20\end{array}$ & $\begin{array}{l}\bar{z} \\
\bar{z} \\
\overline{1} \\
2\end{array}$ \\
\hline $\begin{array}{c}\text { VI } \\
23 / 04 / 74\end{array}$ & $\begin{array}{l}5 \\
4 \\
3 \\
2 \\
1\end{array}$ & $\begin{array}{l}z \\
\bar{z}\end{array}$ & 1 & $\begin{array}{r}\overline{ } \\
\overline{20} \\
31\end{array}$ & $\begin{array}{r}1 \\
4 \\
73 \\
1 \\
-\end{array}$ & $\overline{-}$ \\
\hline $\begin{array}{c}\text { vil } \\
07 / 05 / 74\end{array}$ & $\begin{array}{l}5 \\
4 \\
3 \\
2 \\
1\end{array}$ & $\begin{array}{l}\bar{z} \\
\bar{z}\end{array}$ & - & $\begin{array}{l}\overline{2} \\
\overline{20}\end{array}$ & $\begin{array}{r}- \\
1 \\
5 \\
108 \\
18\end{array}$ & $=$ \\
\hline $\begin{array}{c}\text { VIII } \\
26 / 03 / 74\end{array}$ & $\begin{array}{l}6 \\
5 \\
4 \\
3 \\
2 \\
1\end{array}$ & $\begin{array}{l}\bar{z} \\
\bar{z}\end{array}$ & - & $\bar{z}$ & $\begin{array}{r}31 \\
1 \\
14 \\
- \\
172\end{array}$ & - \\
\hline
\end{tabular}




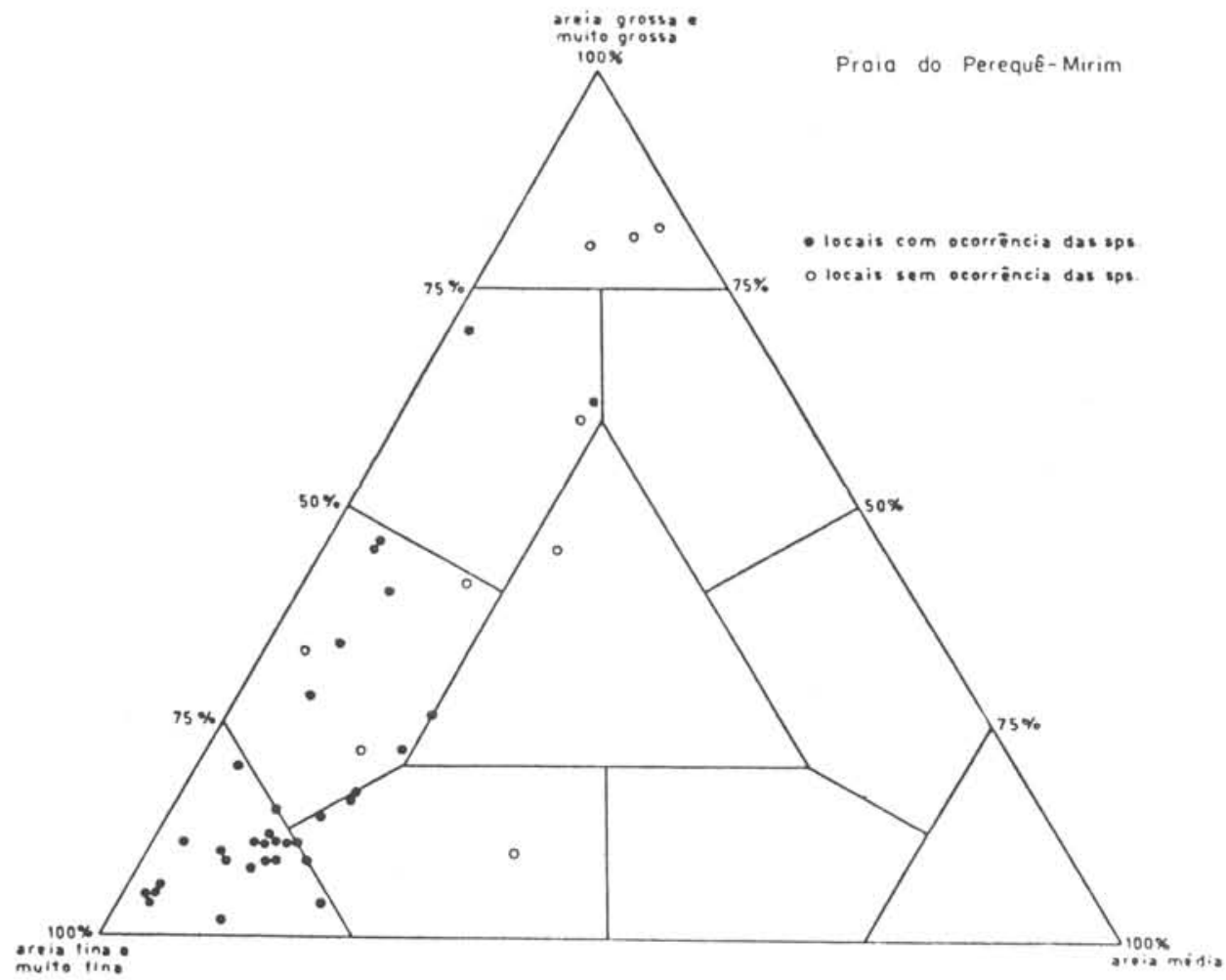

Fig. 15 - Diagrama triangular de Shepard (modificado), das amostras de sedimento.

substrato constituído por partículas de 0,250-0,062 mm. As Figuras 16-17 mostram a grande quantidade de tubos formados na areia em um dos locais de maior densidade da espécie, junto ao costão.

Na Figura 14 onde estão os perfís das radiais amostradas, pode ser notada uma diferença marcante quanto ao gradiente de declividade e largura da faixa de areia fina entre as radiais II - IV e as demais. Talvez a posição geogräfica destes locais na praia, contribuindo para maior influência das ondas, justifique o baixo indice de ocorrência das espécies estudadas.

\section{PRAIA DE SANTA RITA}

Considerações gerais - A Praia de Santa Rita está localizada entre as Praias do Perequê-Mirim e Enseada e, como estas, sofre a influência das ondas vindas do oceano. E uma praia pequena e relativamente estreita.

Resultados e discussão - Os trabalhos de campo foram efetuados no mês 


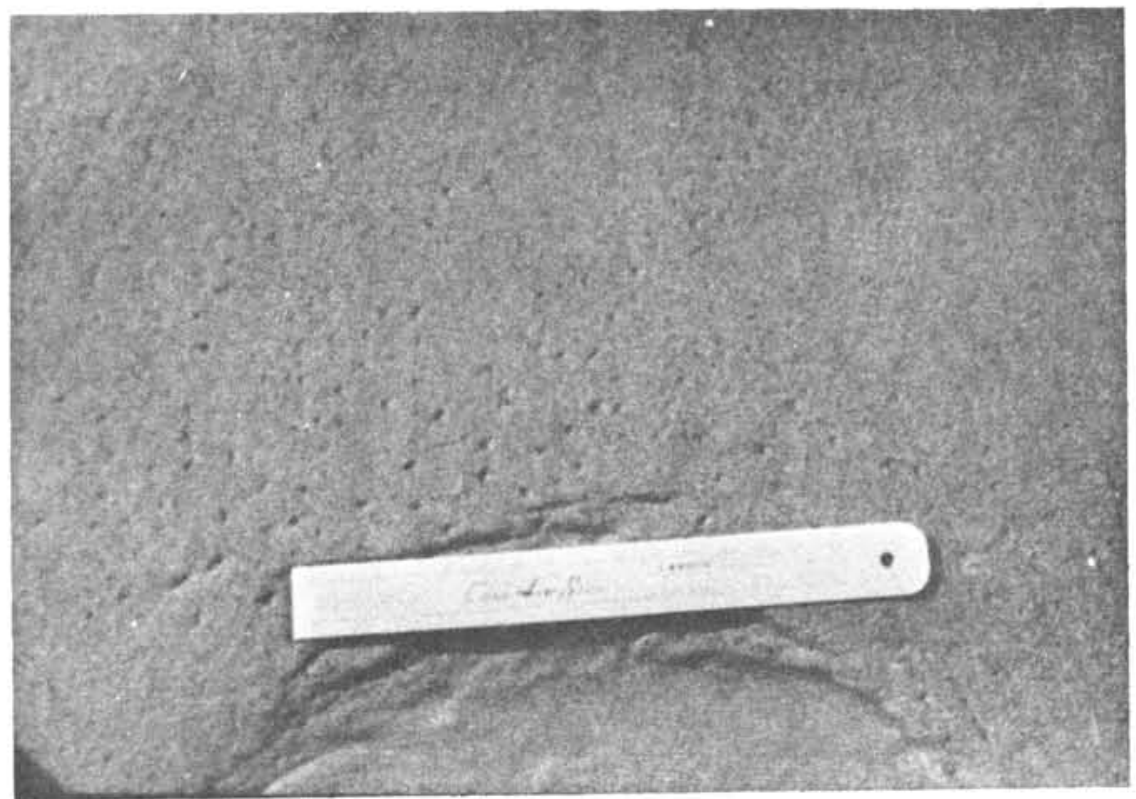

Fig. 16 - Superficie do sedimento com as aberturas dos tubos de Nerine agilis. Praia do Perequê-Mirim.

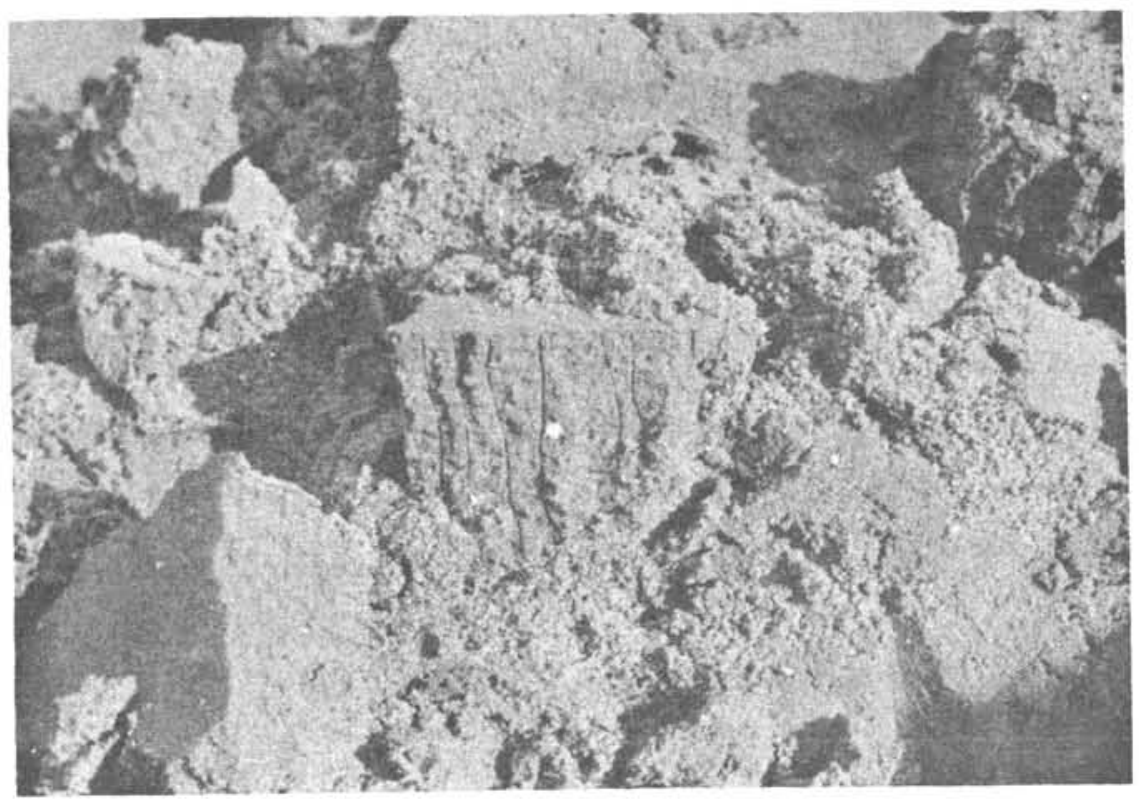

Fig. 17 - Detalhe dos tubos, em corte, de Nerine agilis no interior do sedimento. 
de janeiro de 1974, com 9 estações em 3 radiais. Os resultados das análises físico-químicas estão reunidos na Tabela VII. A salinidade variou entre

TABELA VII - Dados físico-químicos das estações da Praia de Santa Rita

\begin{tabular}{|c|c|c|c|c|c|c|c|c|c|c|}
\hline \multirow{3}{*}{$\begin{array}{l}\text { Radial } \\
\text { (data) }\end{array}$} & \multirow{3}{*}{ Hora } & \multirow{3}{*}{$\begin{array}{c}\text { Loca } 1 \\
\text { de } \\
\text { coleta }\end{array}$} & \multirow{3}{*}{ Āgua } & \multicolumn{3}{|c|}{ I $\left({ }^{\circ} \mathrm{C}\right)$} & \multirow{3}{*}{$\begin{array}{c}S \\
(0 / 00)\end{array}$} & \multirow{3}{*}{$\begin{array}{c}\mathrm{O}_{2} \\
(\mathrm{~m} 1 / 1)\end{array}$} & \multirow{3}{*}{$\begin{array}{c}\mathrm{CaCO}_{3} \\
(\%)\end{array}$} & \multirow{3}{*}{$\begin{array}{l}\text { Matéria } \\
\text { orgânica } \\
\quad(\%)\end{array}$} \\
\hline & & & & & Sedi & ento & & & & \\
\hline & & & & F & Sup. & Fund. & & & & \\
\hline \multirow{4}{*}{$14 / 02 / 75$} & - & 3 & - & 30,0 & 31,0 & 30,0 & - & - & 5,30 & 0,80 \\
\hline & - & 2 & - & 30,0 & 31,0 & 30,0 & 30,66 & 0,59 & 16,80 & 1,30 \\
\hline & - & 1 & - & 30,5 & 31,0 & 30,0 & 28,65 & 4,69 & 14,90 & $-1,40$ \\
\hline & $08: 15$ & Mar & 25,5 & 30,5 & - & - & 33,00 & 4,89 & - & - \\
\hline \multirow{3}{*}{$\begin{array}{c}\text { II } \\
14 / 02 / 75\end{array}$} & - & 3 & - & 30,0 & 30,0 & 29,0 & - & - & 7,20 & 0,60 \\
\hline & - & 2 & - & 29,5 & 29,0 & 29,0 & 30,11 & 0,84 & 5,60 & 1,30 \\
\hline & - & 1 & - & 30,0 & 29,5 & 29,0 & 31,61 & 4,98 & 18,40 & 1,40 \\
\hline \multirow{3}{*}{$\begin{array}{c}\text { III } \\
14 / 02 / 75\end{array}$} & $10: 00$ & 3 & - & 31,5 & 31,0 & 31,0 & - & - & 11,00 & 0,60 \\
\hline & - & 2 & - & 30,0 & 30,0 & 29,0 & 20,66 & 1,43 & 16,10 & 0,90 \\
\hline & - & 1 & - & 30,0 & 29,5 & 29,0 & 30,11 & 4,27 & 11,80 & 1,40 \\
\hline
\end{tabular}

20-33\% \%, tanto para a água do mar como para a intersticial. Os valores de oxigênio dissolvido na água intersticial oscilaram de 0,50-1,43 m1/1. As medidas de temperatura foram elevadas, provavelmente devido à época do ano. Quanto à anālise granulométrica, o tamanho dos grãos de areia variam entre 0,250-0088 mm, areia fina e muito fina (Fig. 18).

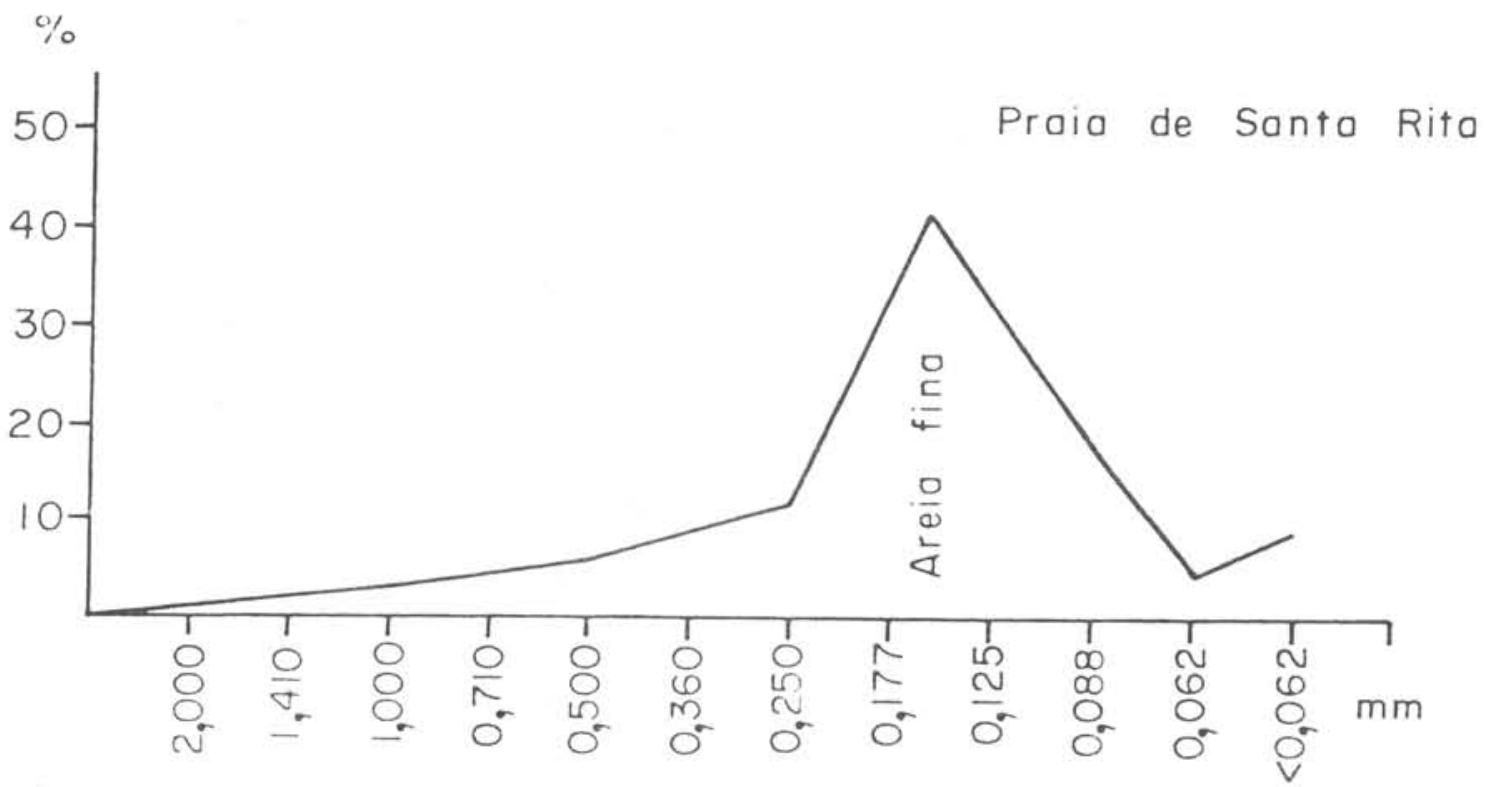

Fig. 19 - Gräfico da freqüência simples da distribuição granulométrica. 
Esta praia revelou os maiores valores em calcário, entre todas aqui estudadas. O conteủdo de matēria orgânica, como nas demais, é relativamente baixo.

A espécie mais abundante foi Armandia agilis (Tab. VIII), cujo habitat mais uma vez coincide com o substrato fino. Foi também registrada a ocorrência de 2 exemplares de Thoracophelia cf. furcifera, espécie até então só assinalada na Praia do Tenório, fora da Enseada do Flamengo.

TABELA VIII - Ocorrência das espécies de poliquetos na Praia de Santa Rita. Número de exemplares em amostras de $1 / 20 \mathrm{~m}^{2}$.

\begin{tabular}{|c|c|c|c|}
\hline 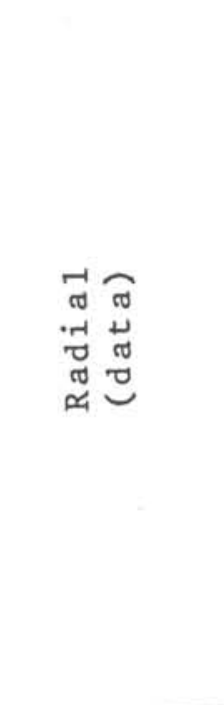 & 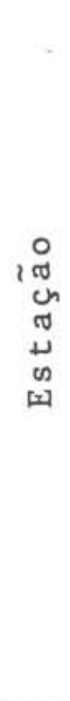 & 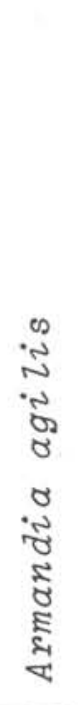 & 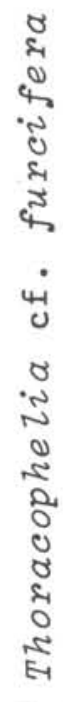 \\
\hline$\frac{I}{14 / 02 / 75}$ & $\begin{array}{l}3 \\
2 \\
1\end{array}$ & $\begin{array}{l}- \\
10\end{array}$ & $\begin{array}{l}- \\
-\end{array}$ \\
\hline $\begin{array}{c}\text { II } \\
14 / 02 / 75\end{array}$ & $\begin{array}{l}3 \\
2 \\
1\end{array}$ & $\begin{array}{r}- \\
1 \\
14\end{array}$ & $\begin{array}{l}2 \\
- \\
-\end{array}$ \\
\hline $\begin{array}{c}\text { III } \\
14 / 02 / 75\end{array}$ & $\begin{array}{l}3 \\
2 \\
1\end{array}$ & $\overline{-}$ & $\begin{array}{l}- \\
-\end{array}$ \\
\hline
\end{tabular}




\section{PRAIAS DA RIBEIRA E FLAMENGO}

Considerações gerais - A praia do Flamengo está mais exposta às vagas que a Praia da Ribeira mas, apesar das localizações geográficas diferirem, as duas praias são muito semelhantes quanto ao relevo e à constituição granulométrica.

Resultados e discussão - As coletas foram realizadas nos meses de janeiro e setembro de 1974, em um total de 3 radiais com 15 estações na Ribeira e 3 radiais com 9 estações na Praia do Flamengo, Figura 19. A salinidade da água do mar ficou entre $30-34 \%$ e a da água intersticial, variou de acordo como declive da praia, caindo a menos de $0,50 \%$ na faixa de areia mais seca, o conteúdo de oxigênio dissolvido é relativamente alto em quase todas as estações, oscilando entre 1,5-4,0 ml/1 de temperatura para o ar, água do mar e sedimento

Praia do

Flamengo
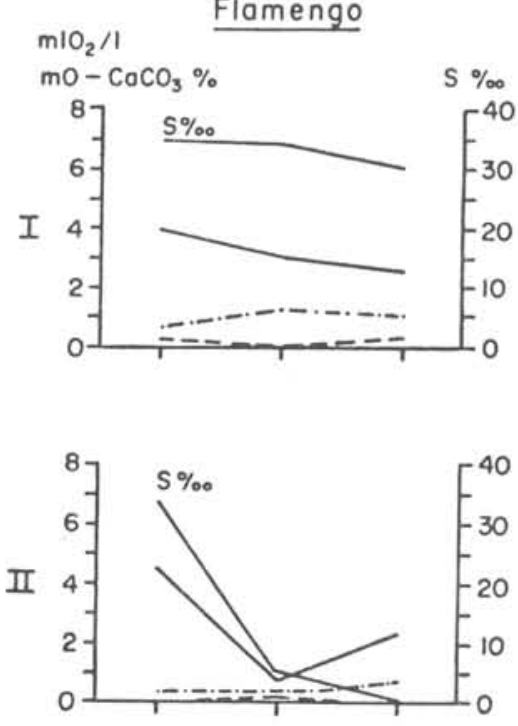

Praia da

$\underline{\text { Ribeira }}$
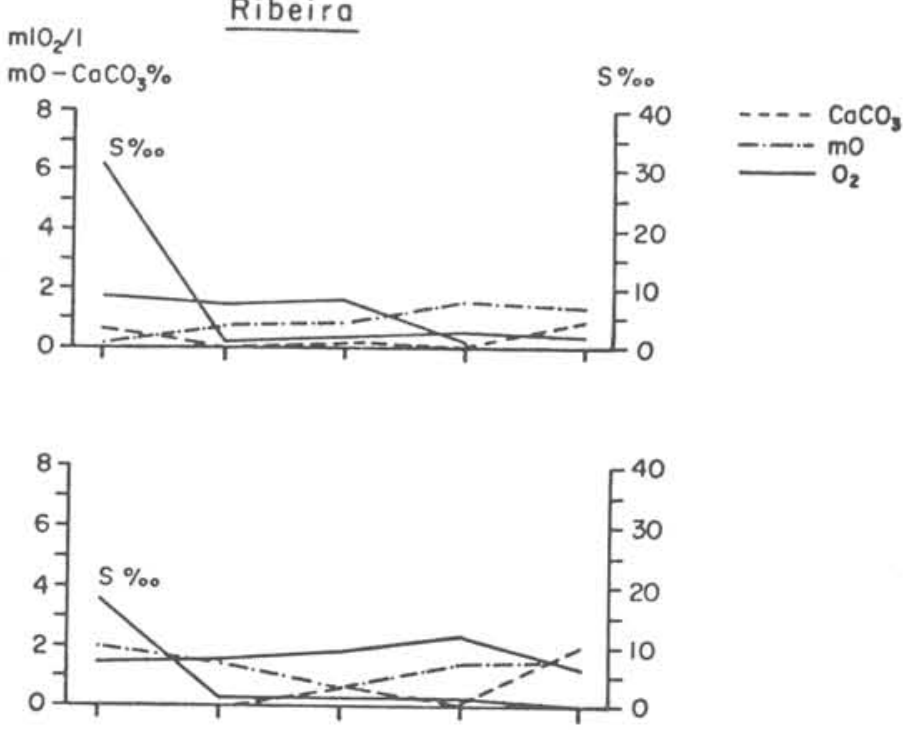
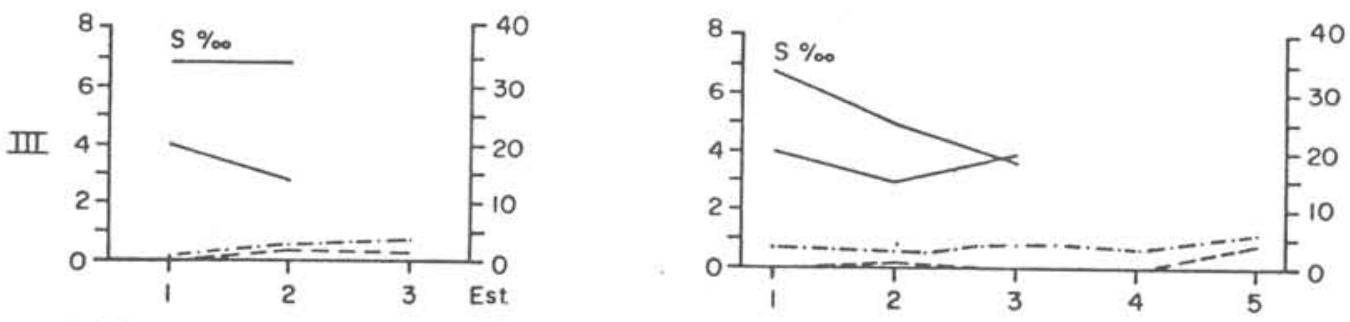

Fig. 19 - Distribuição de alguns parâmetros do sedimento e do ambiente intersticial na Praia da Ribeira e na do Flamengo. 
variaram com a época do ano, as mais altas havendo sido obtidas na Praia da Ribeira, durante o mês de janeıroe as mais baixas em setembro. A análise granulométrica revelou o mesmo tipo de sedimento, isto è, "areia grossa" (Fig. 20). Os resultados referentes aos teores em calcário e matéria orgânica foram baixos; o que pode ser explicado pela maior exposição dessas praias às ondas, condicionando a existência de um sedimento mais revolvido e limpo.

0 número de animais coletados nessas duas praias foi muito pequeno, motivo pelo qual não estão registrados em tabelas. Mas, para um melhor conhecimento desses locais, é feita aqui uma relação das espécies encontradas.

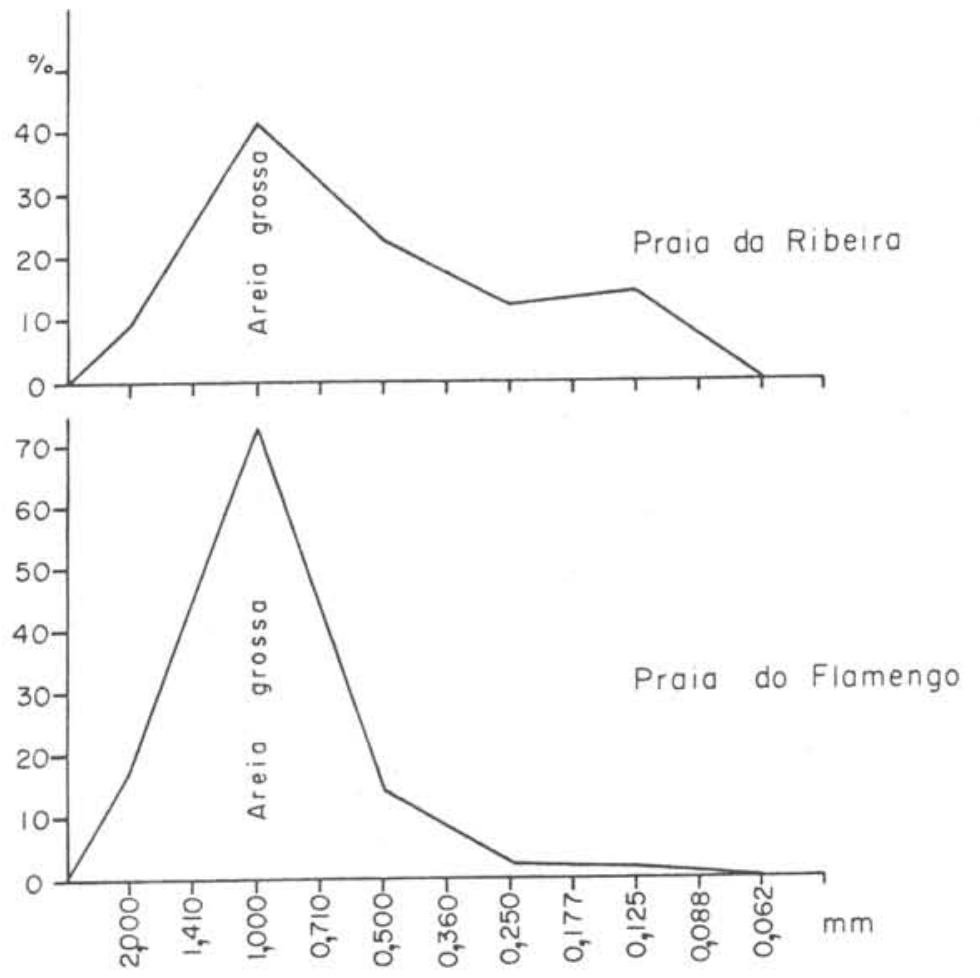

Fig. 20 - Gräfico da freqüência simples da distribuição granulométrica.

Na Praia da Ribeira em dois pontos dos nove amostrados, na zona que corresponde ao médio 1itoral, foram encontrados, 1 exemplar de Laeonereis culveri e 1 de Hemipodus rotundus e em outra estação, mais ao alto da praia, 11 Laeonereis culveri. Na Praia do Flamengo, foi coletado apenas 1 Hemipodus rotundus também no médio 1 itoral.

A pobreza da fauna pode ser justificada pela natureza do substrato e baixo teor em matéria orgânica, ambos conseqüência provável de sua orientação, 
dentro da Enseada do Flamengo.

Os elevados valores de oxigênio dissolvido são coerentes com a rarefação da fauna e com a granulometria dos sedimentos, que nesse caso favorece a uma maior aeração intersticial, circunstância também referida por Brafield (1965).

\section{PRAIAS DA ENSEADA DAS PALMAS - ILHA ANCHIETA}

Considerações gerais - 0 fundo da Enseada das Palmas é formado por quatro praias separadas por trechos de costão rochoso, duas delas com 300 e $800 \mathrm{~m}$ de extensão e uma largura aproximada de $30 \mathrm{~m}$ e duas muito menores. As coletas abrangeram principalmente a Praia Grande, cujas características pareciam ser as mais promissoras. Esta praia localiza-se no extremo oeste da enseada e apresenta uma declividade suave. As demais praias, do Presídio, de Fora e do Engenho, possuem um declive abrupto que se inicia logo abaixo da linha de baixa-mar, com a faixa emersa relativamente muito estreita.

A Ilha Anchieta é alcançada regularmente por água do alto-mar; porém, o efeito da penetração de águas frias na Enseada das Palmas é consideravelmente atenuado, em conseqüência de sua posição abrigada. E característica a permanência de água fria na depressão existente entre a ilha e o continente ("Boqueirão"), cuja profundidade máxima é de cerca de $35 \mathrm{~m}$. Com a ocorrência de ventos intensos, principalmente de sudoeste, as pertubações de superfície' alcançam o fundo, promovendo a rápida mistura das camadas de água, com a conseqüente baixa de temperatura das äguas de superfície. Em determinadas ocasiões, com a coincidência de vārios fatores, o fenômeno é nitidamente revelado pelo afloramento de sedimento do fundo, mesmo em locais com profundidades consideráveis. Supondo que esta peculiaridade alcance as praias da ilha, é provável que constitua um importante fator seletivo para a fauna e flora dessas praias, (Nonato, 1974).

Resultados e discussão - As coletas foram realizadas de setembro a novembro de 1974, em 18 estações distribuídas sobre radiais na Praia Grande e apenas duas estações em cada uma das outras praias, devido às suas estreitas faixas expostas. Os valores dos parâmetros ambientais estão reunidos na Tabela IX e Figura 21. As temperaturas do sedimento, água do mar e ar das quatro praias são semelhantes, embora em alguns pontos da praia a temperatura 
TABELA IX - Dados físico-químicos das estações das Praias de Fora, do Engenho e do Presídio

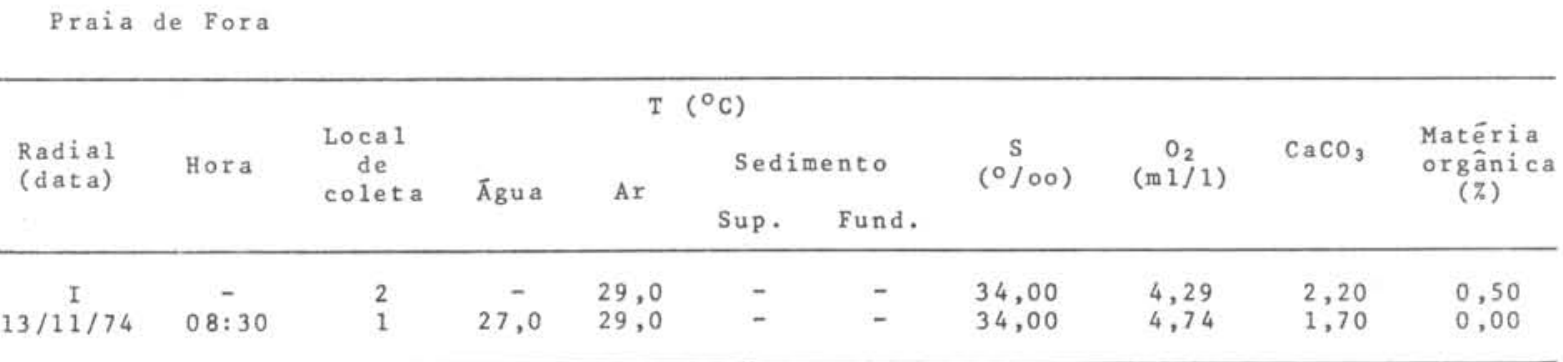

\begin{tabular}{|c|c|c|c|c|c|c|c|c|c|c|}
\hline I & - & 2 & - & - & - & - & 33,50 & 4,44 & 0,90 & 0,10 \\
\hline $13 / 11 / 74$ & $09: 00$ & 1 & 27,0 & 29,0 & - & - & 33,50 & 4,30 & 1,10 & 0,30 \\
\hline
\end{tabular}

Praia do Presídio

\begin{tabular}{ccccccccccccc}
\hline$I$ & - & & & & & & & & & 33,10 & - & 0,70 \\
$13 / 11 / 74$ & $09: 45$ & 1 & 27,5 & 30,0 & - & - & 33,10 & 4,34 & 0,30 \\
\hline
\end{tabular}

do sedimento, atinja vajores mais elevados. A salinidade na Enseada das Palmas é consideravelmente mais baixa $(33,5 \%$ ) que a das águas da parte sul da ilha $(35,0-35,6 \%$ ), diretamente exposta (Nonato, 1974). A salinidade da água intersticial oscilou entre $10-34 \%$ dependendo do local amostrado. Os valores de oxigênio dissolvido ficaram entre 3,00--4,74 ml/1 para água de mar e intersticial das Praias do Presídio, do Engenho e de Fora e entre 0,20$1,33 \mathrm{ml} / 1$, para Praia Grande.

A Praia Grande apresenta em toda a sua extensão areia muito fina (Fig. 22) semelhante à da Praia da Enseada (no continente) possuindo, entretanto, uma fauna mais pobre. As porcentagens de calcário variam de 0,2-4,0\% e o teor em matéria orgânica foi baixo (inferior a 0,70). A Tabela X mostra a ocorrência dos poliquetos nessa praia. Embora não conste da Tabela, pelas razões já mencionadas, è marcante a presença de $A$. brasiliensis, espécie relativamente rara (Wells, 1963), assim como de colônias compactas de Diopatracf. cuprea (Fig. 23). Excetuadas essas ocorrências, a fauna de poliquetos é representada por poucos exemplares das mesmas espécies encontradas regularmente nas praias do continente: Nerine agilis e Armandia agilis. As Praias do Presídio, 

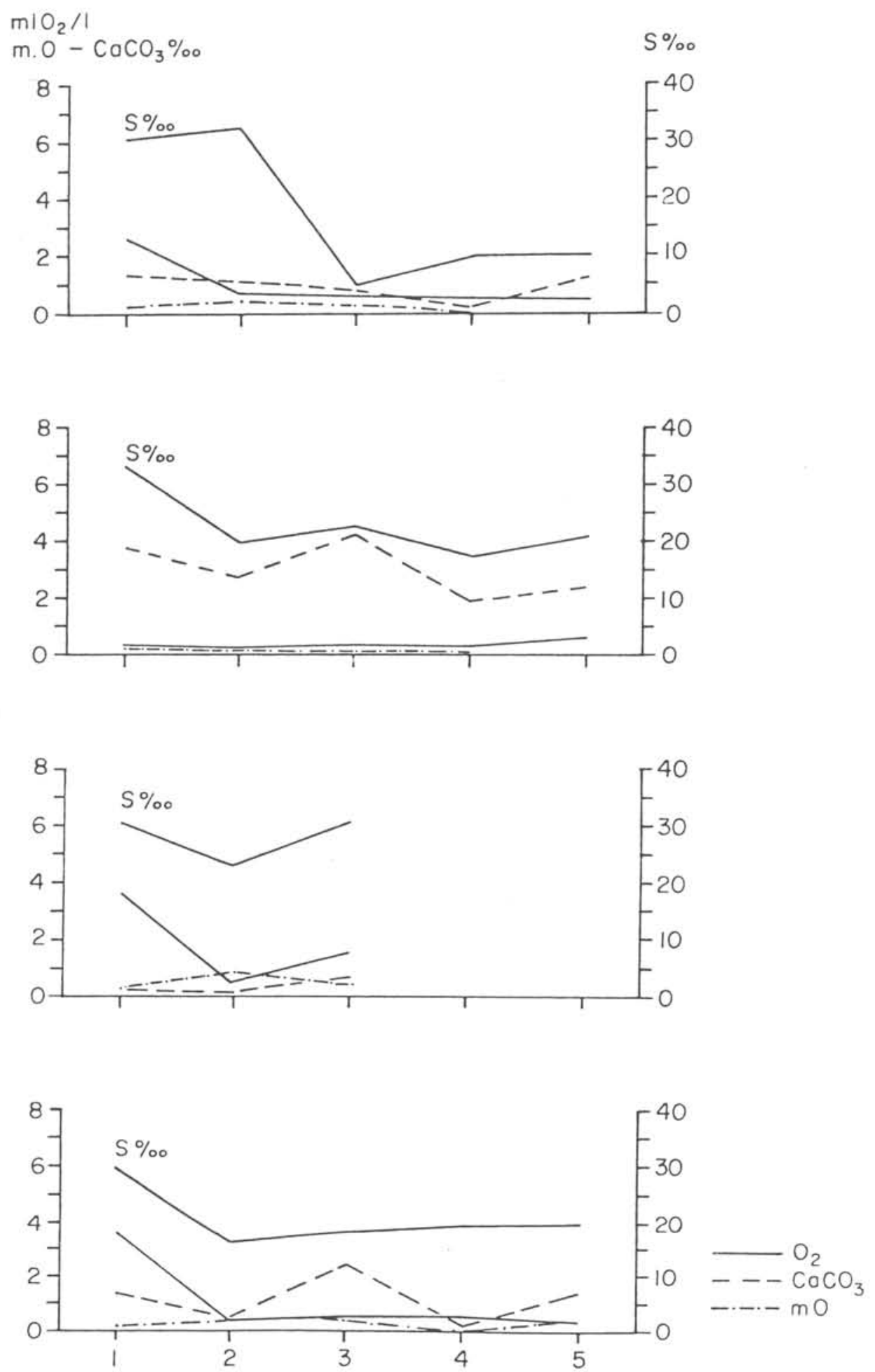

Fig. 21 - Distribuição de alguns parâmetros do sedimento e do ambiente intersticial na Praia Grande. 


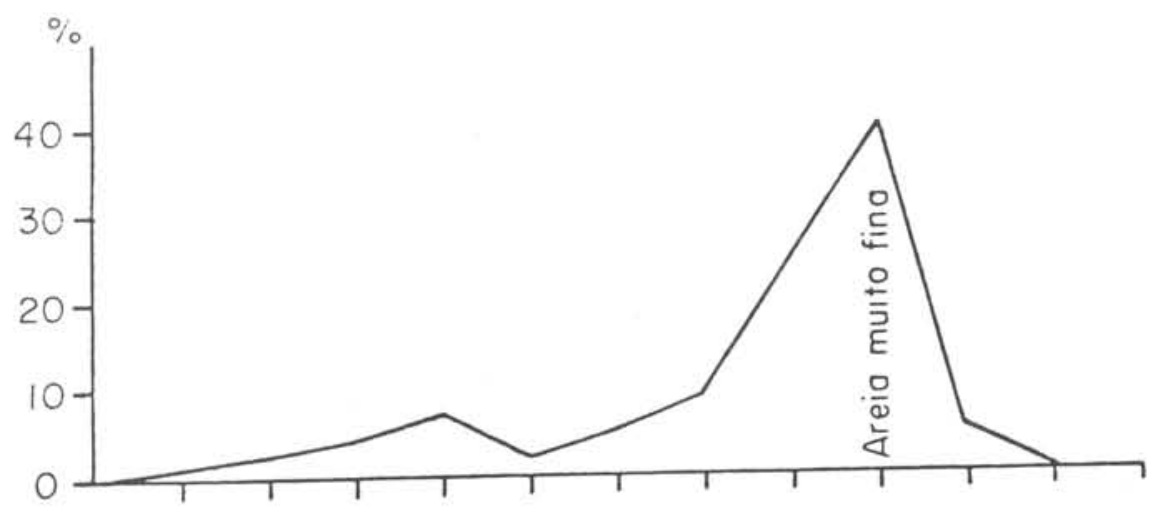

Praia Grande
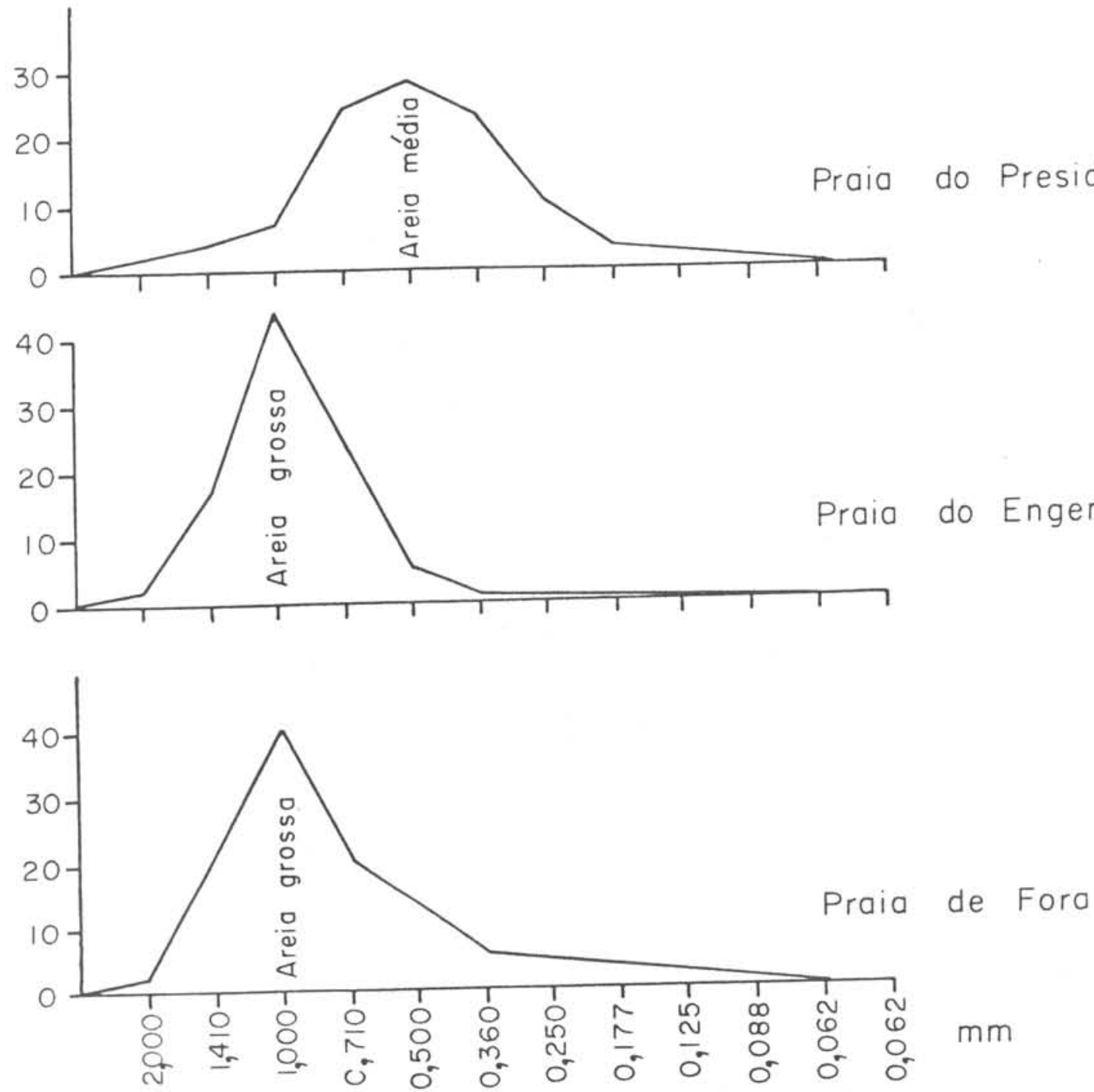

Fig. 22 - Gräficos da freqüência simples da distribuição granulométrica. 
TABELA X - Ocorrência das espécies de poliquetos na Praia Grande - Il ha Anchieta. Nümero de exemplares em amostras de $1 / 20 \mathrm{~m}^{2}$

\begin{tabular}{|c|c|c|c|}
\hline 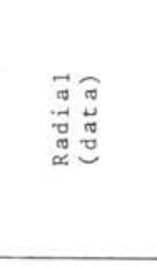 & 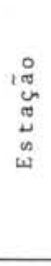 & 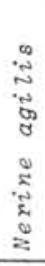 & 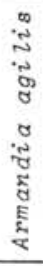 \\
\hline $\begin{array}{c}1 \\
14 / 10 / 74\end{array}$ & $\begin{array}{l}5 \\
4 \\
3 \\
2 \\
1\end{array}$ & $\begin{array}{l}- \\
2 \\
2 \\
1 \\
3\end{array}$ & $\begin{array}{r}- \\
15 \\
46 \\
14 \\
-\end{array}$ \\
\hline $\begin{array}{c}\text { II } \\
14 / 10 / 74\end{array}$ & $\begin{array}{l}5 \\
4 \\
3 \\
2 \\
1\end{array}$ & $\begin{array}{l}\overline{-} \\
\bar{z} \\
\overline{-}\end{array}$ & $\begin{array}{l}- \\
\overline{-} \\
-\end{array}$ \\
\hline $\begin{array}{c}\text { III } \\
04 / 09 / 74\end{array}$ & $\begin{array}{l}3 \\
2 \\
1\end{array}$ & $\frac{4}{1}$ & - \\
\hline $\begin{array}{c}\text { IV } \\
04 / 09 / 74\end{array}$ & $\begin{array}{l}5 \\
4 \\
3 \\
2 \\
1\end{array}$ & $\begin{array}{l}1 \\
2 \\
4 \\
- \\
3\end{array}$ & $\begin{array}{l}\overline{-} \\
\overline{-} \\
\overline{-}\end{array}$ \\
\hline
\end{tabular}

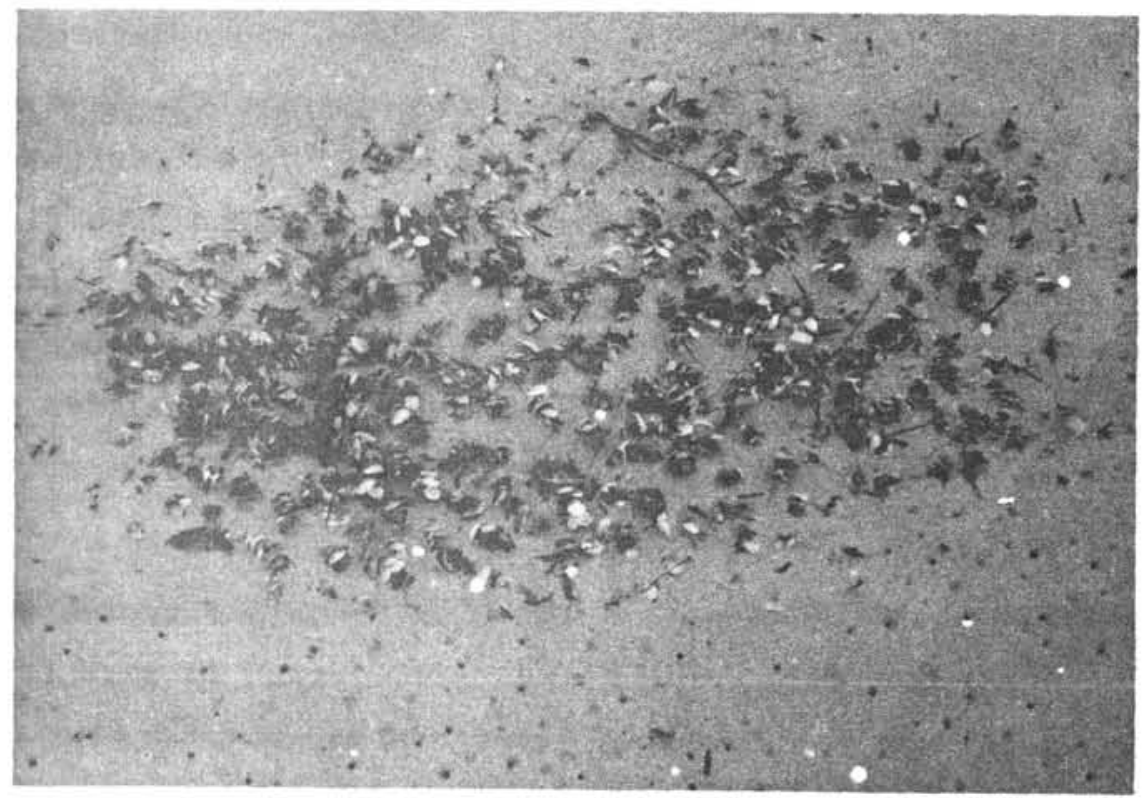

Fig. 23 - Detalhe de uma colônia de Diopatra ef. cuprea, parcialmente soterrada. Praia Grande ( 11 ha Anchieta). 
de Fora e do Engenho, são constituídas por areias mëdia e grossa (Fig. 22), nelas não havendo sido encontrado nenhum exemplar de poliqueto ou de qualquer outra classe de animal da macrofauna. Isto provavelmente é conseqüência da intensa lavagem sofrida pela areia, revolvendo-a totalmente. As amostras de sedimento caracterizam-se por uma ausência quase total de matéria orgânica e uma baixa porcentagem de calcário. O forte gradiente de declividade dessas praias, parece ter influência considerável no tamanho dos grãos de areia, que propiciam um ambiente desfavorável à endofauna (Newel1, 1970).

\section{DISCUSSÃO GERAL}

Como pode ser constatado pelas análises quantitativas, muitas das espécies encontradas têm distribuição característica na região entre-marés. Para compreender essa distribuição, foram estudados os fatores ambientais e feita uma tentativa de correlacioná-1os com as diversas ocorrências.

Porém, alguns dos parâmetros da água intersticial, tais como o oxigênio dissolvido, não puderam ser corretamente relacionados com a presença de determinadas espécies, devidoàs grandes disparidades nos resultados. Os valores de oxigênio dissolvido, obtidos no Saco da Ribeira, revelam que, na maioria das estações localizadas em äreas de sedimento escuro (abaixo de $5 \mathrm{~cm}$ ), ocorre uma ausência de oxigênio aparentemente total. Este fato, parece não ter influência na distribuição das espécies que aí ocorrem, provave1mente porque estas migram periodicamente para as camadas superficiais, onde o teor de oxigênio pode alcançar valores compatíveis com sua existência. Nas Praias da Ribeira, Flamengo, Fora, Engenho e Presídio, os valores de oxigênio foramos mais altos, alcançando $1,5-4,5 \mathrm{ml} / 1$. Nas demais, valores semelhantes aos da água do mar foram encontrados próximo à linha de baixa-mar cuindo para 0,96 e $0,30 \mathrm{ml} / 1$, nas estações mais afastadas.

Comparando os resultados atuais, que revelam baixos teores de oxigênio dissolvido, com os referidos por Brafield (1974, tab. I) para praias arenosas, verifica-se que são inteiramente concordantes. Também, flutuações consideráveis no teor de oxigênio dissolvido foram constatadas pelo mesmo autor, que as atribui a eventuais erros de amostragem, de anälise ou, ainda, à presença de poluentes químicos na região amostrada. 
As variações de temperatura correspondem, aproximadamente, às diferentes épocas do ano. Ainda que seja difícil estabelecer uma relação direta entre tais variações e a presença ou abundância de determinada espécie, os resultados demostram que algumas toleram bastante bem uma amplitude de variação, nu interior dos sedimentos, que vai de $18^{\circ} \mathrm{C}$ (outubro) a $31,5^{\circ} \mathrm{C}$ (fevereiro).

Valores baixos de salinidade foram referidos por Johnson (1967) para as regiões mais altas da praia em profundidade entre 10-20 cm; considerando o autor, que grandes variações de salinidade na zona entre-marés podem constituir um obstáculo para a distribuição dos organismos marinhos. Padrões semethantes aos constatados por Johnson foram observados nas praias aqui estudadas.

Os resultados das medidas de salinidade indicam que muitas espécies exibem certa aptidão para suportar fortes flutuações, caracterizando-se como espécies eurialinas. A Figura 24 mostra as faixas de salinidade toleradas pelas espécies mais abundantes nas āreas estudadas. Essas espécies podem ser

Isaeonereis culveri

Nerine agilis

Heteromastus filiformis

Magezona sp.

Sigambra grubii

Hemipodus rotundus

Diopatra cf. cuprea

Armandia agizis

Prionospio malmgreni
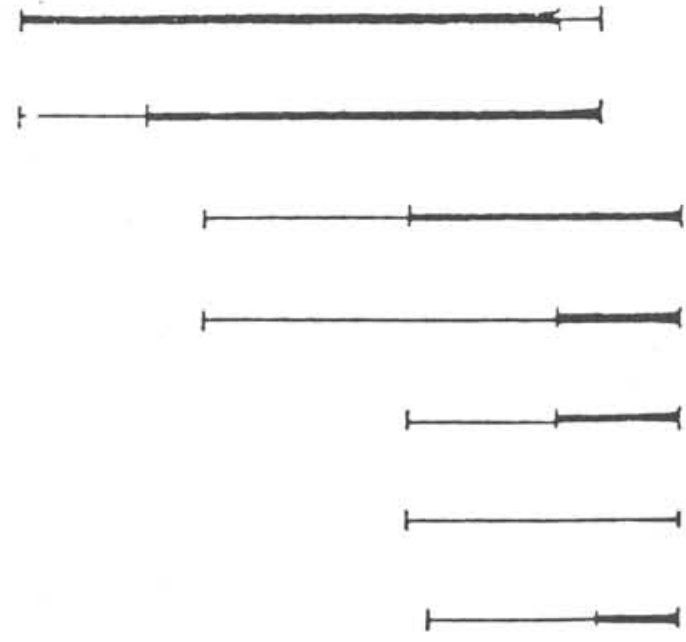

Prionospio malmgreni Fig. 24 - Limites de tolerância de salinidade para algumas espēcies, na ärea
estudada. 
agrupadas em três classes: a) espécies com amplos limites de tolerância, $(2 \% 0-30 \%$ \% , Laeonereis culveri e Nerine agilis; b) espécies com grande intervalo de tolerância, $(11 \%$ - 34\%o), Magelona sp. e Heteronereis filiformis; c) espécies com pequenos limites de tolerância, $(22 \% \circ-34 \%$ \% $)$, reunindo todas as demais.

Uma vez que o tamanho dos grãos de areia e o grau de agitação a que são expostos parecem ter influência tanto na quantidade de água retida pelo sedimento, como aeração e nos teores de matéria orgânica, essas características podem influir decisivamente na distribuição das espécies, na zona entre-marés. Os resultados deste estudo confirmam essa hipótese, sugerindo ainda a existência de uma relação significativa entre o tamanho dos grãos de areia e o número de espécies presentes na área. A ocorrência de um maior número de espécies no Saco da Ribeira, onde predomina a areia média, ao lado de número menor nas rlaias do Perequê-Mirim, Enseada e Santa Rita, onde a areia é fina e da ausência quase total de espécies nas praias de areia grossa da Ribeira, Flamengo e da Ilha Anchieta pode ser atribuída à diferente granulometria dessas praias. Entretanto, o tamanho das partículas do sedimento não deve ser considerado, por si só, fator decisivo na distribuição das espécies estudadas .

Para uma avaliação do grau de diversidade das espécies por praia, foi aplicado o método da rarefação proposto por Sanders (1968). Esse método, que permite uma comparação direta do número de espécies nas amostras reduzindoas a um tamanho comum, foi usado pelo autor para avaliar o grau de diversidade para duas classes de animais, com vārias espécies. Sua aplicaçãoé particularmente ütil no caso de espécies com distribuição ao acaso (aleatória); porém, mesmo considerando espécies com distribuição agregada, é possível obter-se a diversidade inerente. Para tanto, devem ser eliminadas as de maior agregação, uma vez que sua inclusão elevaria excessivamente os valores. Para o estudo comparativo foram utilizadas somente as praias mais representativas da ārea (Fig. 25). As espécies abundantes ou de comportamento agregado, como Laeonereis culver e Capitella capitata para o Saco da Ribeira e Nerine agilis para Enseada e Perequê-Mirim, foram eliminadas. A Praia do Saco da Ribeira constitui um ambiente especial, com sedimento, conteúdo de oxigênio dissolvido e salinidade bem características, apresentando ao lado de um ele- 


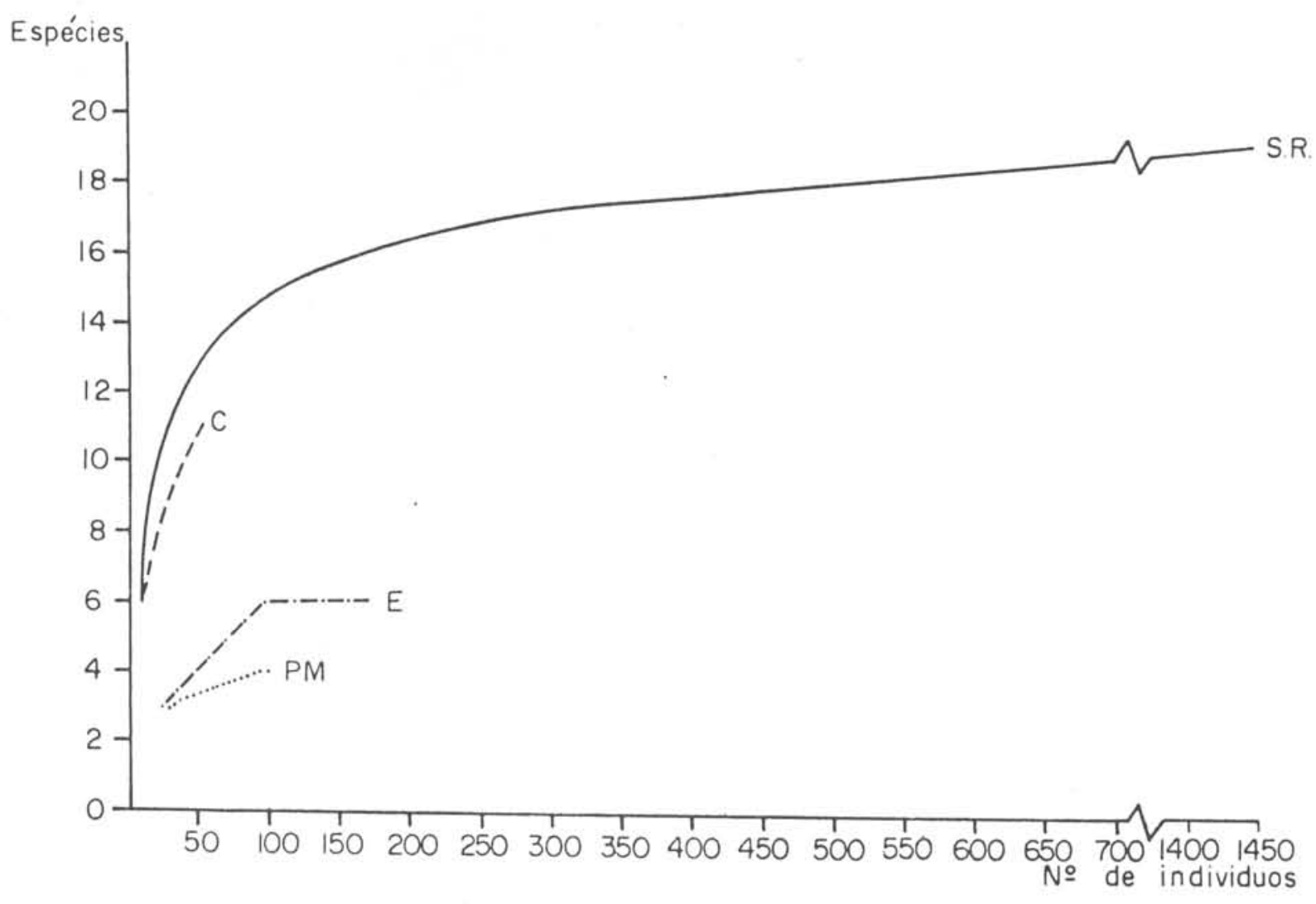

Fig. 25 - Curvas de diversidade para espëcies de poliquetos das praias: Saco da Ribeira (SR), Codó (C), Enseada (E) e Perequê-Mirim (PM).

vado número de indivíduos um alto grau de diversidade. Já a praia contígua do Codó mostra alto grau de diversidade mas poucos indivíduos. As respectivas curvas provavelmente poderiam ser consideradas paralelas, em decorrência da semelhança entre ambas. Porëm, como a amostragem na Praia do Codó foi limitada, por várias razões, a uma estreita faixa emersa, o reduzido número de exemplares coletados não permite uma comparação mais ampla.

Como era de se esperar, as Praias da Enseada e Perequê-Mirim, que mostraram ser bastante semelhantes em relação aos parâmetros ambientais, apresentam curvas similares, com baixo número de espécies e um número considerável de indivíduos. A Praia de santa Rita, também revelou-se bastante semelhante a essas duas com relação aos aspectos físico-químicos porēm, devido provavelmente à sua localização geográfica, possui menor número de espécies e indivíduos. Segundo Trevallion et al. (1970) estes resultados são característicos de praias tropicais. 
Como pode ser constatado, as praias aqui estudadas, divergem quanto ao tipo de sedimento, gradiente de declividade eutros aspectos físico-químicos. A não ocorrência de espécies comuns a todas as praias pode ser atribuída a essas diferenças que alteram consideravelmente as condições biológicas. Hemipodus rotundus, é a espécie que ocorre em maior número de praias não similares, mostrando assim certo grau de adaptação a diferentes tipos de habitat. Armandia agilìs está presente em vārias praias de características semelhantes, exceto a do Saco da Ribeira (Tab. XI).

Comparando as espécies encontradas na Enseada do Flamengo e na Enseada das Palmas, nota-se que as duas praias com maior similaridade são, sem dúvida, a Praia da Enseada e a Praia Grande; onde tanto os fatores físico-químicos como as espécies encontradas são equivalentes. Esses dois locais, são caracterizados pela presença marcante de Arenicola brasiliensis e Diopatra ef. cuprea, espécies bem adaptadas para a existência em ambientes expostos à arrebentação, porém com substrato coerente, que assegura a integridade de suas galerias ou tubos. As observações quanto à segunda espécie confirmam a sua importância para a consolidação da praia, havendo indícios sugestivos de que suas colônias contribuem para o enriquecimento orgânico de uma praia que, de outra forma, seria praticamente desértica. A ocorrência de um elevado nümero de Arenicola brasiliensis, espécie rara em toda a ārea, é assegurada pela abundância de alimento propiciada pelas colônias de Diopatra, quer acumulando detritos vegetais, que utilizam para revestir seus tubos, quer pelos resỉduos de sua alimentação.

A contribuição para a biomassa das espécies de anelídeos poliquetos mais abundantes e de maior volume, foi avaliada somente para a Praia do Saco da Ribeira. Ainda que significativa, a biomassa è relativamente pequena quando comparada com a dos lamelibrânquios e crustáceos, abundantes nessa área. 0 mesmo pode ser dito em relação à Praia da Enseada, onde as observações quantitativas indicam situação análoga. Porém, nas Praias de Santa Rita no continente, e Grande na Ilha Anchieta, onde os poliquetos constituem praticamente o único grupo representativo da macrofauna na zona das marés, tal contribuição é importante. 
TABELA XI - Ocorrência das espëcies de poliquetos nas praias estudadas

ESPECIES

Pвeudeurythoe" ambigua

Podarke pallida

Loandalia amerioana

Sigambra grubii

Sylizo oornuta

Laeonereis oulveri

Neanthes op.

Nereis (Perinereis) melanoosphala

Nephtyo caeca

Glycera americana

Bemipodus rotundus

Glycinde multidene

Diopatra cf. cuprea

Onuphis nebulosa

LHBidice ninetta

Lumbrineris sp.

Lumbrineris paradoxa

Lumbrineris tetraura

Dorvizlea sp.

Naineris setosa

Scolaricia sp.

Aricidea fauve $l i$

Dispio uncinata

Nerine agilis

Prionoвpio sp.

Prionospio malmgreni

Mage Zona sp.

Armandia agilis

Thoracophelia cf. furcifera

Capite zla capitata

Beteromastus filiformis

Notomastus sp.

Arenicola brasiliensis

owenia fusiformis

Pectinaria laelia

Ioolda pulchelza

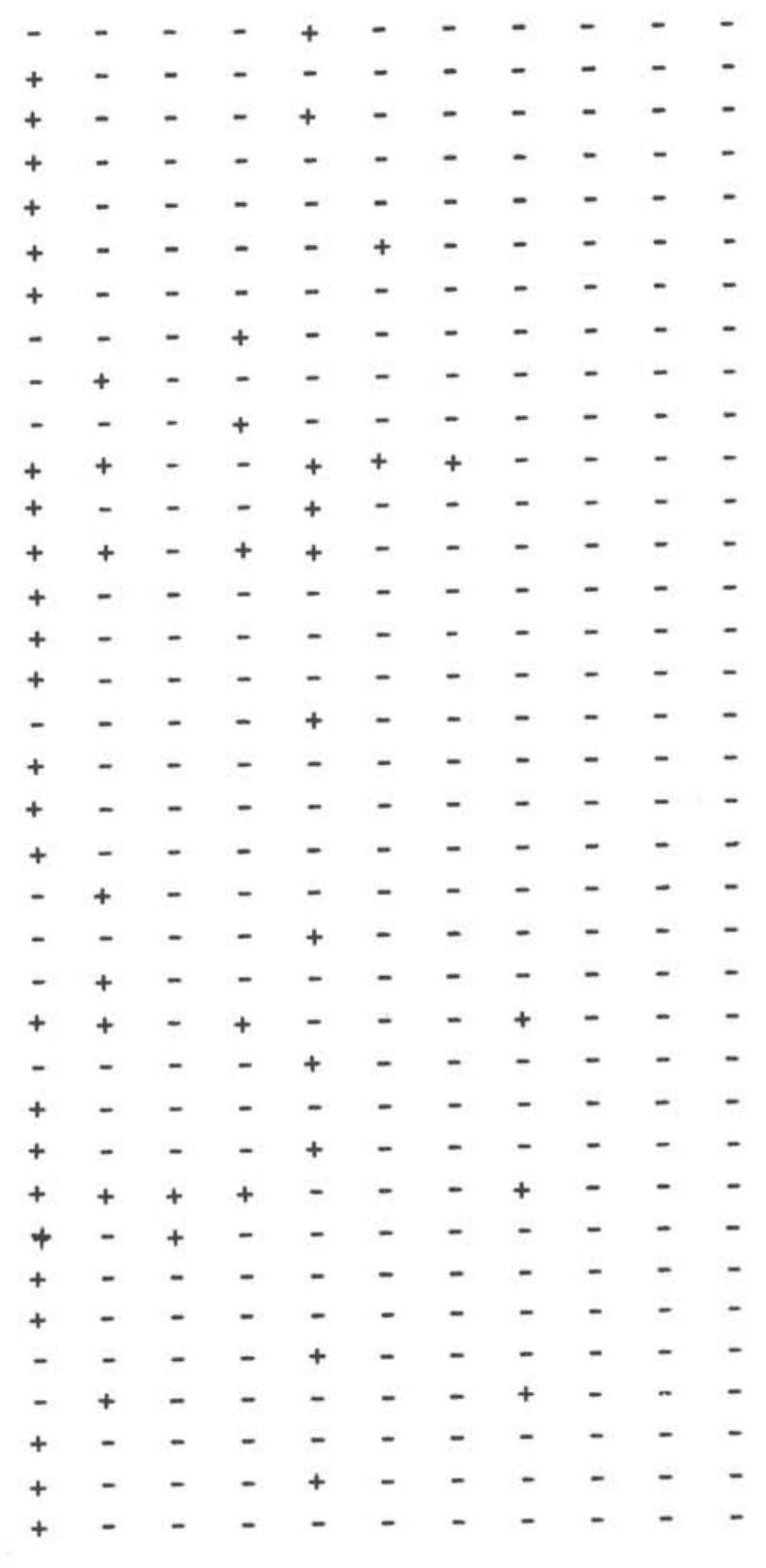




\section{CONCLUSÕES}

Os resultados obtidos através das medidas dos parâmetros ambientais e da amostragem biológica em 191 pontos, distribuídos em vārios níveis da zona das marés, evidenciam que não só a granulometria do substrato mas também, as características da água intersticial e o teor em matéria orgânica dos sedimentos têm papel relevante no condicionamento da endofauna das praias do $1 \mathrm{i}-$ toral norte do Estado de São Paulo.

Comprovou-se ainda que a aparente ausência de fauna em praias com arrebentação intensa é real e conseqüência direta da extrema mobilidade dos sedimentos, constituídos na maioria das vezes por areia grossa. Essa situação é bem evidente em praias da Ilha Anchieta (Presídio, Engenho e da Fora), expostas à arrebentação e em praias com condições semelhantes, na Enseada do Flamengo (Ribeira e Flamengo).

Quando a areia da praia é fina e homogênea, constitui um substrato compacto, praticamente imune à ação normal das vagas. Esse tipo de substrato ocorre na Praia da Enseada (no continente) e Praia Grande da Ilha Anchieta, onde a amostragem revelou ambientes bastante semelhantes. Nelas constatou-se a existência das mesmas espécies de poliquetos, duas das quais com importante distribuição: Arenicola brasiliensis e Diopatra cf. cuprea. 0 poliqueto Nerine agilis, que também ocorreu nestas e em outras praias com caracterís-' ticas análogas, mostra ter preferência por esse tipo de substrato.

Os fatores mais seletivos foram a salinidade e o teor de matéria orgânica. Quanto à importância da salinidade, os resultados são coerentes com os referidos na bibliografia especializada. Espécies amplamente eurialinas, como Laeonereis culveri e Nerine agilis têm uma larga distribuição na faixa entre-marés, alcançando, entretanto, sua concentração máxima em áreas de salinidade abaixo de $10 \%$. Tais espécies podem ser consideradas como reciprocamente exclusivas. Tendo em conta que ambas são "comedoras de detritos", os fatores limitantes, no substrato seriam o tamanho dos grãos e o teor de matéria orgânica. Esses fatores condicionam, não só a ocorrência, como a densidade das colônias de cada uma das espécies.

Para explicar a presença de elevado número de organismos, em ambientes 
que se revelam pela amostragem totalmente carentes de oxigênio, foi feita a hipótese de que os mesmos migram periodicamente para camadas superiores, com teor de oxigênio mais a1to. Porēm, é igualmente razoável admitir que no amr biente intersticial, ao nível em que vivem os animais, o teor de oxigênio dissolvido seja, na realidade, suficiente para lhes assegurar condições suportāveis. A atividade redutora dos sulfetos presentes nesse nível não será, nas condições naturais, suficiente para esgotar o oxigênio da água intersticial.

A Praia do Saco da Ribeira que constitui um ambiente bastante especial em relação aos demais, mostrou ser a mais diversificada da região estudada. Devido à alta ocorrência de Laeonereis culveri e o grande volume de Diopatra cf. cuprea, estas espécies contribuem significativamente para a sua biomassa. A praia em questão e a da Enseada revelaram um certo grau de poluição, que provavelmente teve influência marcante nos resultados.

\section{RESUMO}

A pesquisa visou ao conhecimento das condições biológicas de algumas praias do litoral norte do Estado de São Paulo, tendo sido os poliquetos os organismos indicadores.

0 material estudado proveio de um total de 191 estações, distribuídas em vārios níveis da zona das marēs, em onze praias da Enseada do Flamengo (continente) e Enseada das Palmas (Ilha Anchieta). Em cada estação foi amostrada uma ārea de $1 / 20 \mathrm{~m}^{2}$, com uma profundidade de $10 \mathrm{~cm}$ e medidos a temperatura, $\mathrm{pH}$, salinidade e o teor de oxigênio dissolvido da água intersticial. Simultaneamente foram coletadas amostras da ägua do mar ao nível da baixamar, para medida dos mesmos parâmetros. As amostras de sedimento colhidas entre 5 e $10 \mathrm{~cm}$ de profundidade, foram analisadas quanto à granulometria, porosidade, conteúdo de calcário e de matéria orgânica.

Os resultados mostram que tanto a granulometria, e o teor de matéria orgânica do substrato quanto às características da água intersticial têm papel relevante no condicionamento da endofauna dessas praias. Observou-se ainda ausência de macrofauna em praias de areia grossa com arrebentação intensa. Quando a areia da praia é fina e homogênea, constitui um substrato 
compacto, praticamente imune à ação das vagas. Esse tipo de substrato ocorre na Praia da Enseada (no continente) e Praia Grande da Ilha Anchieta. Nessas praias constatou-se a existência das mesmas espécies de poliquetos: Nerine agilis, Arenicola brasiliensis e Diopatra cf. cuprea.

Os fatores mais seletivos forama salinidade e o teor de matéria orgânica. As espëcies amplamente eurialinas, como Laeonereis culveri e Nerine agilis têm uma larga distribuição na faixa entre-marés; porém alcançam sua maior concentração em āreas de salinidade abaixo de $10 \%$.

A Praia do Saco da Ribeira mostrou ser a mais diversificada, com 20 espécies de poliquetos, entre as quais Laeonereis culveri e Diopatra cf. cuprea, que, devido à alta freqüência, contribuem significantemente para a biomassa da área. Esta praia e a da Enseada revelaram certo grau de poluição que provavelmente tem também influência marcante sobre a seleção e distribuição da fauna.

\section{AGRADECIMENTOS}

Ao Dr. Edmundo Ferraz Nonato agradeço pela orientação, incentivo e dedicação constantes durante este trabalho.

Agradeço à Fundação de Amparo à Pesquisa do Estado de São Paulo, pelo apoio dado através da concessão de bolsa (Proc. Biológicas 73/357).

Ao Instituto Oceanográfico da Universidade de São Paulo, agradeço pela utilização da Base Norte e pelas facilidades concedidas no decorrer desta pesquisa. E a todos aqueles cujo auxílio me permitiu concluir com sucesso esta pesquisa.

\section{B IBLIOGRAF I A}

AMOUREUX, L. 1966. Etude bionomique et écologique de quelques annélides polychétes des sables intertidaux des côtes ouest de la France. Archs Zoo1. exp. gén., 1:1-218, 25 figs, 29 tabs.

BRAFIELD, A. E. 1964. The oxygen content of interstitial water in sandy shores. J. Anim. Ecol., 33(1):97-116, 6 figs, 7 tabs.

1965. Quelques facteurs affectant 1a teneur en oxygène des eaux interstitielles 1ittorales. Vie Milieu, 17(2-B):889-897. 
BRASIL. DIRETORIA DE HIDROGRAFIA E NAVEGAÇÃO. 1973-1975. Tábuas das marés para os anos de 1973, 1974 e 1975. Costa do Brasil e portos estrangeiros.

HARVEY, H. W. 1955. The chemistry and fertility of sea waters. Cambridge, Univ. Press, viii +224 .

JOHNSON, R. G. $1967 . \quad$ Salinity of interstitial water in a sandy beach . Limno1. oceanogr., 12(1):1-7, 1 fig., 3 tabs.

MAGLIOCCA, A. \& KUTNER, A. S. 1965. Sedimentos de fundo da Ens eada do Flamengo-Ubatuba. Contrções Inst. oceanogr., Univ. S Paulo, sér. Ocean. Fís., (8): $1-14$.

NEWELL, R. C. 1970 Biology of intertidal animals. London, Lagos Press, 555 p.,figs, tabs.

NONATO, E. F. 1958. Sobre duas arenicolas da costa brasileira. Contrções Inst. oceanogr., Univ, S Paulo, sér. Ocean. Biol., (3):1-6, 6 figs.

fado).

1974 .

Relatório sobre a Ilha Anchieta, (mimeogra-

PERKINS, T. H. \& SAVAGE, T.

1975. A bibliography and check list of polychaetous annelids of Florida, the Gulf of Mexico and the Caribbean region. Florida Mar. Res. Pub1., 14:1-62.

PETTIBONE, M. H. 1971. Revision of some species referred to Leptonereis, Nicon, and Laeonereis (Polychaeta: Nereididae). Smithson. Contr. Zoo1. (104):1-53, 27 figs.

REISH, D. J. 1955. The relation of polychaetous annelids to harbor pollution. Pub1. H1th Rep. Wash., 70(2):1168-1174, $1 \mathrm{fig.,} 2$ tabs, 1 mapa.

1973a. The use of benthic animals in monitoring the marine environment. J. Envir. P1ann. Pollut. Control., 1(3):32-38, 6 figs.

1973b. Marine and estuarine pollution. J. Wat. Pollut. Control Fed., WPCF, 45(6):1310-1319.

RETIERE, C. 1968. Contribution à l'étude écologique de la macrofaune annélidienne de la Plage de Lancieux (Côtes-du-Nord). Bull. Lab . marit. Dinard, $1(1): 5-63$.

SANDERS, H. L. 1968. Marine benthic diversity: a comparative study . Amer. Nat., 102(925):243-281, 18 figs, 3 tabs.

SHEPARD, F. P. \& MOORE, D. G. 1954. Sedimentary environments differentiated by coarse-fraction studies. Bull. Am. Ass. Petro1. Geol., 38: 1792-1802. 
STRICKLAND, J. D. H. \& PARSONS, T. R. 1968. A practical handbook of seawater analysis. Bul1. Fish. Res. Bd Can., (167):1-311.

SUGUIO, K. 1973. Introdução à sedimentologia. São Paulo, Blucher/ EDUSP, 312 p., 99 figs, 21 tabs.

TREVAllion, A.; ANSEll, A. D.; SIVADAS, P. \& NARAYANAN, B. $1970 . \quad$ A preliminary account of two sandy beaches in South West India. Mar. Bio1., $6(3): 268-279$.

WELLS, G. P. 1963. Barriers and speciation in lugworms. Systematics Assoc. Pub1., (5):79-98, figs 1-6.

WENTWORTH, C. K. 1922. A scale of grade and class terms for clastic sediments. J. Geo1., 30:377-392.

(Recebido em 25/novembro/1977) 